\title{
17. BIOSTRATIGRAPHY AND PALEOECOLOGY OF NEOGENE AND OLIGOCENE SILICOFLAGELLATES FROM CORES RECOVERED DURING ANTARCTIC LEG 28, DEEP SEA DRILLING PROJECT
}

\author{
Paul F. Ciesielski, Antarctic Research Facility, \\ Department of Geology, Florida State University, Tallahassee, Florida
}

\section{INTRODUCTION}

During Leg 28 of the Deep Sea Drilling Project, sixteen holes were drilled at eleven sites: one site on the Naturaliste Plateau, five sites between the Southeast Indian Ridge and the Wilkes Land coast of Australia, one site on the Antarctic continental rise distal to the Ross Sea, and four sites in the Ross Sea. All sites, with the exception of Site 264, lie south of the present position of the Antarctic Convergence and within Subantarctic or Antarctic waters. In the present study of silicoflagellate biostratigraphy and paleoecology, eleven holes from eight of these Leg 28 sites are utilized (Table 1, Figure 1).

At Site 264, drilled on the Naturaliste Plateau, silicoflagellates were recorded only in one core of upper Eocene calcareous nannofossil ooze. The three pelagic sites (Sites 266, 267, 269) located in the highly productive waters south of the Southeast Indian Ridge all contain abundant silicoflagellates in Plio-Pleistocene sedimentary sequences. Upper Miocene to middle middle Miocene sections (Sites 266, 267, 269, 274) are generally barren or contain low-diversity, cold-water assemblages, whereas lower middle Miocene to lower Miocene silicoflagellate assemblages are more diverse and contain frequent warm-water cosmopolitan species. A unique 140-meter-thick lower Oligocene sequence with an abundant and diverse assemblage of relatively warm-water silicoflagellates was drilled on the continental rise at Site 274. Site 274 provides an abundance of data on the stratigraphic distribution of Oligocene silicoflagellates; until now, such information has been relatively sparse. At almost all sites the consistent presence and abundance of silicoflagellates is exceeded only by that of the diatoms.
Continuous or near continuous coring and a relatively high rate of recovery at two sites (Sites 266 and 274) has provided a nearly complete stratigraphic sequence of Neogene and Oligocene silicoflagellate assemblages. A biostratigraphic zonation is established for most of the Neogene and Oligocene and includes fifteen zones and two subzones. Paleomagnetically dated Eltanin piston cores (Table 2), representing the Brunhes through Gilbert magnetic epochs, have been used to relate the zonal scheme to paleomagnetic chronostratigraphy. Whenever possible, older silicoflagellate zones have been related to calcareous nannofossil stratigraphy. Noticeable differences between this silicoflagellate zonation and other previously established zonations (Figure 2 ) underscores the provinciality of most Neogene silicoflagellate assemblages in the Antarctic and Subantarctic. Only a few cosmopolitan zones, such as the middle Miocene Corbisema triacantha Zone and the lower Miocene Naviculopsis Zones, are recognized.

A newly developed silicoflagellate paleotemperature technique (Ciesielski, 1974) has been utilized for a detailed study of early Pliocene sedimentary sequences in six Eltanin piston cores and two Leg 28 drill cores. The delineated silicoflagellate paleotemperatures suggest that a dramatic change in the thermal structure of the Southern Ocean occurred during the Gilbert magnetic epoch, with a fluctuating drop in surface water temperatures from more than $10^{\circ} \mathrm{C}$ (present-day northernmost Subantarctic) to less than $2.0^{\circ} \mathrm{C}$ (presentday Antarctic). Inferred surface water temperatures between 4.30 and 3.95 m.y. B. P. are suggested as being too warm for the existence of the West Antarctic ice sheet during that time.

Relative paleotemperature (Ts) values for the Miocene and Oligocene sequences at Sites 266 and 274

TABLE 1

Holes Drilled During Leg 28, DSDP

\begin{tabular}{lccccrrr}
\hline Hole & Latitude & Longitude & $\begin{array}{c}\text { Water } \\
\text { Depth }(\mathrm{m})\end{array}$ & $\begin{array}{c}\text { Pene- } \\
\text { tration }(\mathrm{m})\end{array}$ & $\begin{array}{r}\text { No. of } \\
\text { Cores }\end{array}$ & $\begin{array}{c}\text { Meters } \\
\text { Cored }\end{array}$ & $\begin{array}{c}\text { Meters } \\
\text { Recovered }\end{array}$ \\
\hline 264 & $34^{\circ} 58.13^{\prime} \mathrm{S}$ & $112^{\circ} 02.68^{\prime} \mathrm{E}$ & 2873 & 215.5 & 15 & 142.5 & 65.2 \\
266 & $56^{\circ} 24.13^{\prime} \mathrm{S}$ & $110^{\circ} 06.70^{\prime} \mathrm{E}$ & 4173 & 384.0 & 24 & 219.5 & 145.2 \\
267 & $59^{\circ} 15.74^{\prime} \mathrm{S}$ & $104^{\circ} 29.30^{\prime} \mathrm{E}$ & 4564 & 219.5 & 7 & 58.0 & 25.9 \\
$267 \mathrm{~A}$ & $59^{\circ} 15.74^{\prime} \mathrm{S}$ & $104^{\circ} 29.30^{\prime} \mathrm{E}$ & 4564 & 70.5 & 3 & 28.5 & 11.6 \\
$267 \mathrm{~B}$ & $59^{\circ} 14.55^{\prime} \mathrm{S}$ & $104^{\circ} 29.94^{\prime} \mathrm{E}$ & 4539 & 323.0 & 10 & 95.0 & 53.5 \\
269 & $61^{\circ} 40.57^{\prime} \mathrm{S}$ & $140^{\circ} 04.21^{\prime} \mathrm{E}$ & 4285 & 397.5 & 11 & 103.0 & 38.8 \\
271 & $76^{\circ} 43.27^{\prime} \mathrm{S}$ & $175^{\circ} 02.86^{\prime} \mathrm{E}$ & 562 & 554.0 & 24 & 233.0 & 15.3 \\
272 & $77^{\circ} 07.62^{\prime} \mathrm{S}$ & $176^{\circ} 45.61^{\prime} \mathrm{W}$ & 629 & 443.0 & 48 & 439.0 & 162.0 \\
273 & $74^{\circ} 32.29^{\prime} \mathrm{S}$ & $174^{\circ} 37.57^{\prime} \mathrm{E}$ & 495 & 76.0 & 9 & 76.0 & 27.9 \\
$273 \mathrm{~A}$ & $74^{\circ} 32.29^{\prime} \mathrm{S}$ & $174^{\circ} 37.57^{\prime} \mathrm{E}$ & 495 & 346.5 & 29 & 256.5 & 55.5 \\
274 & $68^{\circ} 59.81^{\prime} \mathrm{S}$ & $173^{\circ} 25.64^{\prime} \mathrm{E}$ & 3326 & 421.0 & 45 & 421.0 & 279.1 \\
\hline
\end{tabular}




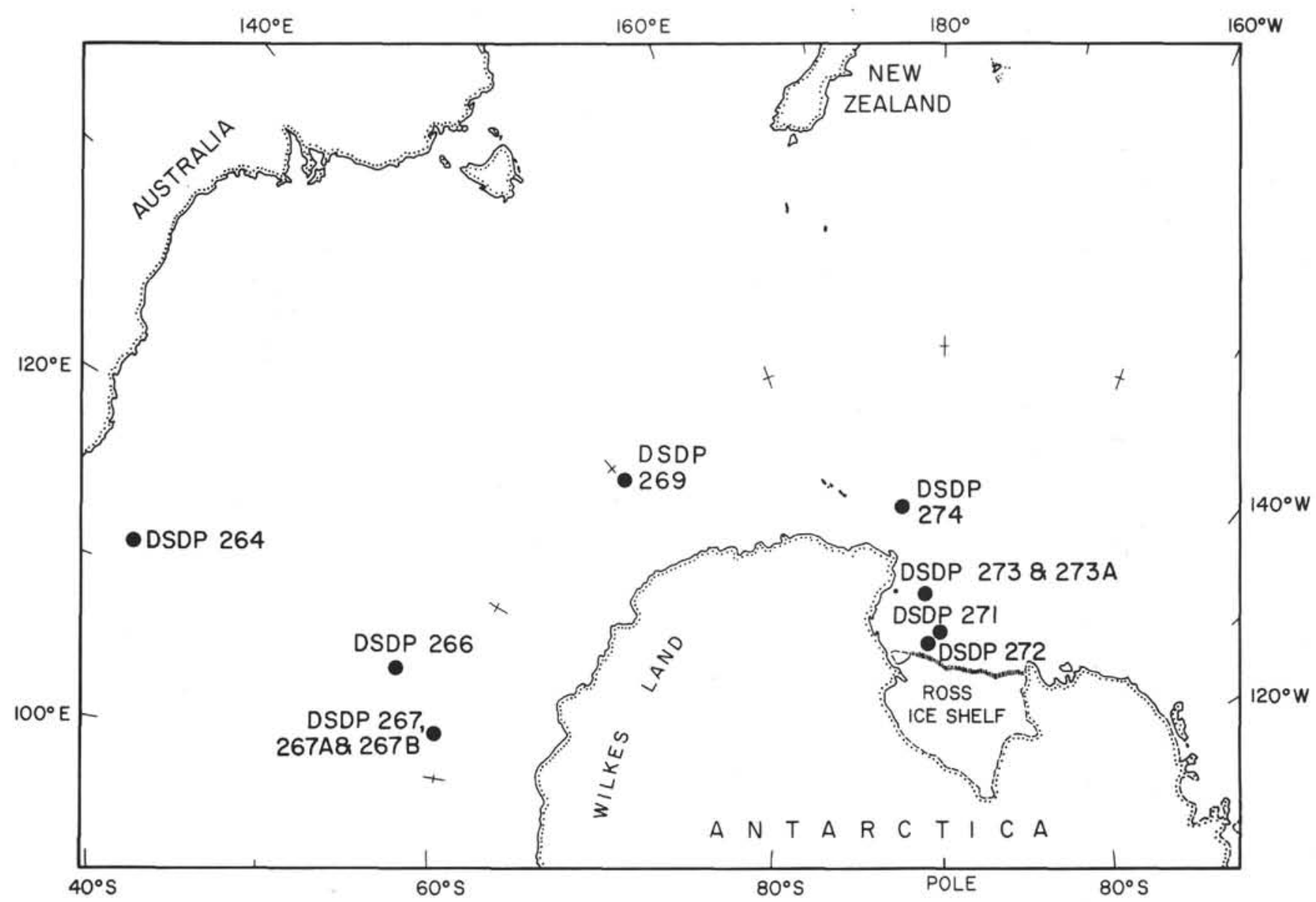

Figure 1. Locations of Deep Sea Drilling Project Leg 28 holes for which silicoflagellate assemblages are cited.

TABLE 2

Southern Ocean Paleomagnetically Dated Eltanin Piston Cores Utilized to Establish a Silicoflagellate Biostratigraphic Zonation for the Past 4.65 m.y.B.P.

\begin{tabular}{lcccl}
\hline Core & Latitude & Longitude & $\begin{array}{c}\text { Water } \\
\text { Depth } \\
\text { (Fathoms) }\end{array}$ & Paleomagnetic Age \\
\hline $14-8$ & $59^{\circ} 40.0^{\prime} \mathrm{S}$ & $160^{\circ} 17.4^{\prime} \mathrm{W}$ & 2120 & Recent-Gilbert “B" \\
$13-17$ & $65^{\circ} 41.0^{\prime} \mathrm{S}$ & $124^{\circ} 06.3$ ' $\mathrm{W}$ & 2583 & Recent-Gilbert "C" \\
$38-7$ & $61^{\circ} 49.3^{\prime} \mathrm{S}$ & $149^{\circ} 53.0^{\prime} \mathrm{E}$ & 2000 & Lower Matuyama-Lower Gilbert \\
$32-48$ & $67^{\circ} 00.0^{\prime} \mathrm{S}$ & $176^{\circ} 16.0^{\prime} \mathrm{E}$ & 1928 & Lower Gauss \\
$50-28$ & $62^{\circ} 54.2^{\prime} \mathrm{S}$ & $150^{\circ} 41.2^{\prime} \mathrm{E}$ & 1908 & Lower Gauss-Upper Gilbert \\
$36-33$ & $57^{\circ} 46.3^{\prime} \mathrm{S}$ & $154^{\circ} 55.0^{\prime} \mathrm{E}$ & 1877 & Lower Gauss-Upper Gilbert \\
$38-8$ & $61^{\circ} 48.6^{\prime} \mathrm{S}$ & $149^{\circ} 54.2^{\prime} \mathrm{E}$ & 1800 & Upper Gilbert \\
\hline
\end{tabular}

are presented along with carbonate and quartz percentages. Detailed discussions of paleoecology, paleoclimatology, biostratigraphy, and systematic paleontology of the material recovered are presented in the following sections of this report.

\section{PREPARATION OF SAMPLES AND METHOD OF STUDY}

Samples for shore-laboratory study of silicoflagellates were taken aboard D/V Glomar Challenger by the shipboard diatomist Mr. David McCollum.
Eltanin samples utilized in this study were obtained at the Florida State University Antarctic Research Facility.

Some shipboard core-catcher slide preparations made by $\mathrm{D}$. McCollum were utilized in this study. The shipboard processing procedure used on these core-catcher samples varied with the type of sediment and the degree of lithification. Sediments composed primarily of calcium carbonate were treated with $10 \% \mathrm{HCl}$ and the undissolved portion centrifuged and decanted several times to concentrate the diatom and silicoflagellate 


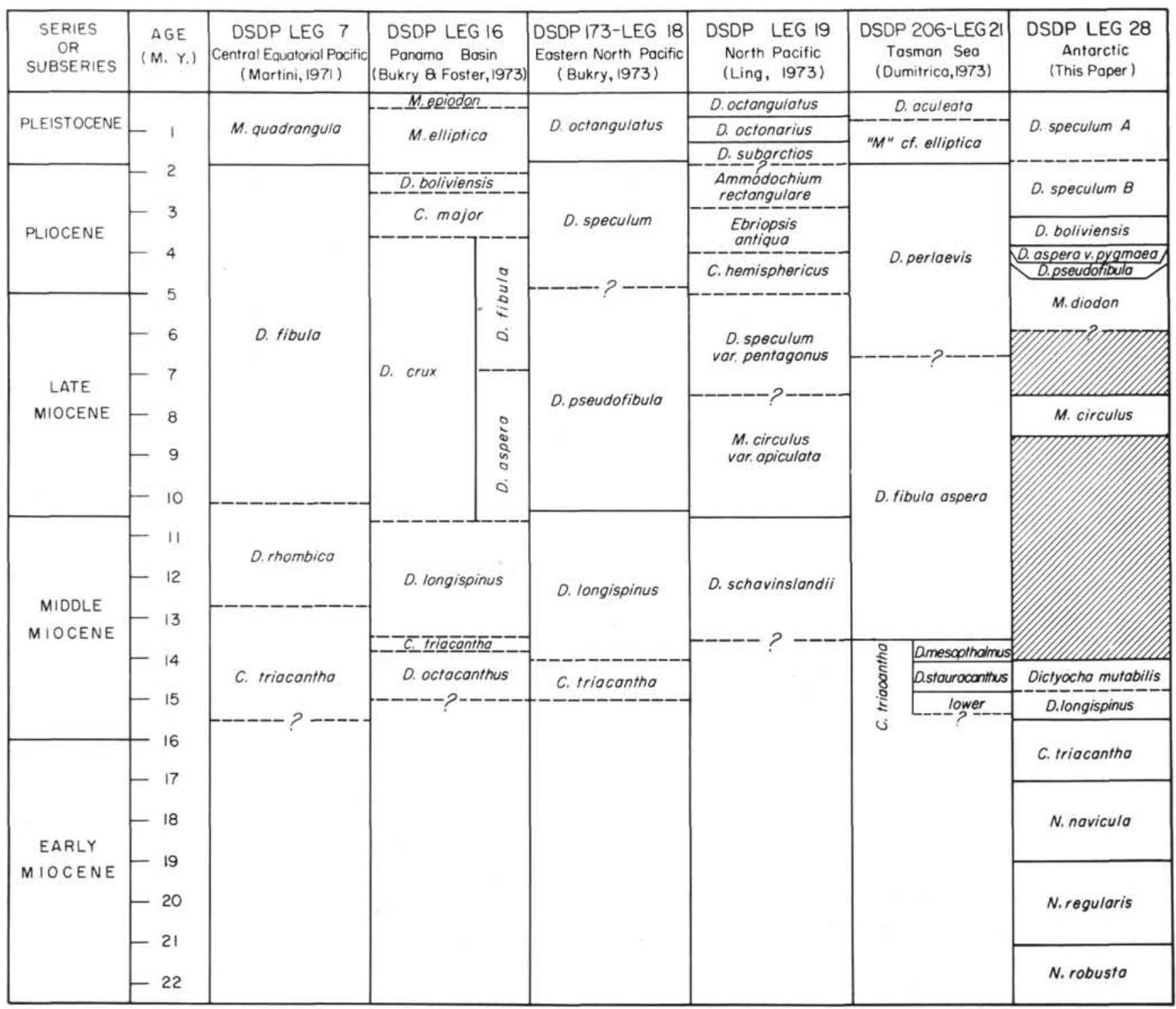

Figure 2. Comparison of early Miocene to Pleistocene silicoflagellate zones in deep-sea sediments.

remains. This method was used primarily on samples from Sites 264, 266, and 267. When siliceous microfossil abundances were high, core-catcher samples were untreated, and slides were made of the raw sample (Sites 269 and 274). In instances where the sediment was semilithified (Sites 272 and 273) and siliceous microfossil abundances were low, the sediment was disassociated with hot $50 \%$ hydrogen peroxide. The disassociated sediment was then filtered through $25 \mu, 38 \mu$, and $63 \mu$ sieves. A slide was made for each fraction, including the unsieved portion.

Shore-laboratory Eltanin and Glomar Challenger samples were treated as follows: Samples of approximately $1 \mathrm{cc}$ were placed in clean $200-\mathrm{ml}$ beakers with $15 \mathrm{ml}$ of $30 \%$ hydrogen peroxide and heated until the sediment was disassociated and activity was negligible. Fifteen $\mathrm{ml}$ of reagent grade $\mathrm{HCl}$ were then added, and heating continued until activity of the acid was reduced. Heating time for the samples varied with the sediment type and the degree of lithification. Samples were then diluted with $50 \mathrm{ml}$ of distilled water and transferred to $110-\mathrm{ml}$ centrifuge tubes. This suspension was centrifuged at $2000 \mathrm{rpm}$ for $3 \mathrm{~min}$, decanted, and the residue diluted with distilled water. The procedure was repeated two more times. The residue was then added to $50 \mathrm{ml}$ of $0.5 \%$ sodium pyrophosphate solution and centrifuged again. This step was repeated two additional times. After the last centrifugation and decanting, $50 \mathrm{ml}$ of distilled water were added to the residue and the suspension placed in labeled plastic bottles. Each sample was shaken thoroughly and a small amount of suspension pipetted from the middle of the bottle. Two drops of the pipette suspension were placed on a $22 \mathrm{~mm} \times 22$ $\mathrm{mm}$ cover slip and dried on a slide warmer. When dry, two drops of Hyrax were added and heated until the volatile components evaporated. The cover slip was taken upon a heated slide and then allowed to cool.

Slide examinations were made with a Zeiss Photomicroscope II. Specimen counts were done in brightfield illumination at magnifications of $250 \times$ and $650 \times$. 
All specimens, whole or consisting of more than half a skeleton, were counted. All slides were systematically scanned in their entirety by consecutive traverses using a mechanical stage. Counts of two slides were made at some sample intervals in sections of particular stratigraphic significance where less than 100 specimen counts were obtained from the first slide. Sections where this procedure was followed include: Site 274, lower Oligocene; Site 267, upper Oligocene; and Site 266, lower Miocene.

\section{ZONAL CHARACTERISTICS}

\section{Distephanus speculum Zone A}

Top: Not defined, but the zone includes all floras above the initial consistently common occurrence of long-spined Distephanus speculum morphotypes.

Base: First consistently common occurrence of longspined Distephanus speculum in the absence of Distephanus boliviensis.

Age: Early Pleistocene-Recent: Matuyama and Brunhes paleomagnetic epochs.

Important characteristics of the zonal assemblage: This zone is characterized by the consistently common occurrence of long- and short-spined morphotypes of Distephanus speculum. Other species present sporadically through the zone are Distephanus speculum var. pentagonus, D. speculum var. septenarius, Dictyocha fibula, and Dictyocha aspera. Common to abundant Distephanus polyactis are found only in the lower portion of the zone which is within the Matuyama paleomagnetic epoch.

Reference section: Site $269: 61^{\circ} 40.57^{\prime} \mathrm{S}, 140^{\circ} 04.21^{\prime} \mathrm{E}$ and E14-8: $59^{\circ} .0^{\prime} \mathrm{S}, 160^{\circ} 17.4^{\prime} \mathrm{W}$.

Occurrence of zone: Continuously cored at Site 274 and discontinuously cored at Sites 269 and 266.

Correlation: In paleomagnetically dated Eltanin piston cores the lower boundary of this zone is approximately correlative with the Gauss-Matuyama magnetic epoch boundary (2.43 m.y.B.P.).

\section{Distephanus speculum Zone B}

Top: First consistently common occurrence of longspined Distephanus speculum in the absence of Distephanus boliviensis.

Base: Last consistently common occurrence of Distephanus boliviensis in the presence of a Distephanus speculum group dominated by short-spined morphotypes.

Age: Late Pliocene: within Gauss paleomagnetic epoch.

Important characteristics of the zonal assemblage: The zone is characterized by the consistently common to abundant occurrence of short-spined Distephanus speculum and rare to few long-spined Distephanus speculum. Short-spined $D$. speculum are consistently more abundant than long-spined $D$. speculum. Species present sporadically through the zone are Dictyocha pseudofibula, D. aspera, D. fibula, Distephanus boliviensis, D. sp. cf. boliviensis, and Distephanus speculum var. pentagonus. Abundant Distephanus speculum var. pentagonus forma armatus, observed at the base of this zone, at Site 266, may provide a useful datum within the lower portion of this zone.

Reference section: Site $266: 56^{\circ} 24.13^{\prime} \mathrm{S}, 104^{\circ} 29.30^{\prime} \mathrm{E}$ and E14-8: $59^{\circ} 40.0^{\prime} \mathrm{S}, 160^{\circ} 17.4^{\prime} \mathrm{W}$.

Occurrence of zone: Continuously cored at Site 274 and intermittently cored at Sites 266, 267, and 269.

Correlation: In paleomagnetically dated Eltanin piston cores this zone is present throughout the Gauss magnetic epoch between the Gauss-Matuyama boundary (2.43 m.y.B.P.) and the base of the Mammoth event (3.085 m.y.B.P.)

\section{Distephanus boliviensis Zone}

Top: Last consistently common occurrence of Distephanus boliviensis in the presence of a Distephanus speculum group dominated by short-spined morphotypes.

Base: Last common occurrence of Dictyocha aspera var. pygmaea and Dictyocha fibula var. pumila.

Age: Middle Pliocene: lower Gauss-upper Gilbert paleomagnetic epochs.

Important characteristics of the zonal assemblage: This zone is characterized by the consistent occurrence of common to abundant Distephanus boliviensis, D. sp. cf. boliviensis, and D. speculum s.l. Species occurring more sporadically but with a similar abundance include Distephanus speculum var. pentagonus, D. boliviensis var. major, D. boliviensis var. binoculus, and Dictyocha pentagona. The lower portion of the zone, within the upper Gilbert, contains a significant warm-water assemblage component which includes Dictyocha aspera, D. fibula, and $D$. perlaevis.

Reference section: Eltanin piston core 5028: $62^{\circ} 54.2^{\prime} \mathrm{S}, 150^{\circ} 41.2^{\prime} \mathrm{E}$.

Occurrence of zone: Continuously cored at Site 274 and discontinuously cored at Site 266 .

Correlation: In Eltanin cores from this region of the Southern Ocean this zone occurs within the lower Gauss and upper Gilbert magnetic epochs, between 3.085 and 3.82 m.y.B.P.

\section{Dictyocha aspera var. pygmaea- \\ Dictyocha fibula var. pumila Zone}

Top: Last common occurrence of $D$. aspera var. pygmaea and $D$. fibula var. pumila.

Base: First common occurrence of $D$. aspera var. pygmaea and D. fibula var. pumila.

Age: Early Pliocene: Gilbert paleomagnetic epoch.

Important characteristics of the zonal assemblage: This zone is characterized by common to abundant occurrence of Dictyocha aspera var. pygmaea, D. fibula var. pumila, D. aspera, D. fibula, Distephanus boliviensis, and D. sp. cf. boliviensis; and few to common Dictyocha perlaevis. Other species occurring sporadically include Distephanus boliviensis var. major, $D$. boliviensis var. binoculus, D. crux, D. speculum var. pentagonus, Dictyocha pentagona, and Mesocena cf. elliptica.

Reference section: Eltanin piston core 388: $61^{\circ} 48.6^{\prime} \mathrm{S}, 149^{\circ} 54.2^{\prime} \mathrm{E}$.

Occurrence of zone: Discontinuously cored at Sites 266 and 267. 
Correlation: In three Eltanin piston cores off Wilkes Land, Antarctica, E 38-8, E 50-28, and E 36-33, this zone occurs in the Gilbert magnetic epoch between events "a" and "b" (3.82-3.97 m.y.B.P.). In E 14.8, off West Antarctica; this zone is confined to sediments within the Gilbert event "a" (3.72-3.82 m.y.B.P.).

\section{Dictyocha pseudofibula Zone}

Top: The first common occurrence of Dictyocha aspera var. pygmaea and Dictyocha fibula var. pumila.

Base: First common occurrence of Dictyocha pseudofibula.

Age: Middle early Pliocene; Mid-Gilbert paleomagnetic epoch.

Important characteristics of the zonal assemblage: The zone is characterized by common to abundant Dictyocha pseudofibula, D. aspera, D. fibula, Distephanus boliviensis, and $D$. boliviensis sp. cf. boliviensis. Less common species occurring sporadically include: Distephanus crux, D. speculum var. pentagonus, $D$. boliviensis var. major, D. boliviensis var. binoculus, and Dictyocha pentagona.

Reference sections: Eltanin piston core 388: $61^{\circ} 48.6^{\prime} \mathrm{S}, 149^{\circ} 54.2^{\prime} \mathrm{E}$; and $\mathrm{E} 14-8 ; 59^{\circ} 40.0^{\prime} \mathrm{S}$, $160^{\circ} 17.4^{\prime} \mathrm{W}$.

Occurrence of zone: Continuously cored at Site 274 and discontinuously cored at Sites 267 and 269.

Correlation: In Eltanin piston cores E 38-8 and E 14-8 the top of this zone occurs between Gilbert magnetic events "a" and "b" (3.82-3.97 m.y.B.P.) and in E 14-8 the bottom of this zone occurs between Gilbert magnetic events "b" and "c" (4.14-4.33 m.y.B.P.).

\section{Mesocena diodon Zone}

Top: The first common occurrence of Dictyocha pseudofibula.

Base: The first consistent occurrence of Mesocena diodon. Last consistent occurrence of $M$. circulus.

Age: Late Miocene-early Pliocene.

Important characteristics of the zonal assemblage: This zone is characterized by a low-diversity assemblage dominantly comprised of Distephanus speculum s.l., D. crux, and Mesocena diodon. Minor constituents of the zonal assemblage which occur sporadically include Distephanus speculum var, pentagonus, $D$. boliviensis, $D$. sp. cf. boliviensis, Dictyocha pseudofibula, D. aspera, $D$. aspera var. pygmaea, and D. fibula var. pumila.

Reference section: Eltanin piston core E 13-17: $65^{\circ} 41.0^{\prime} \mathrm{S}, 124^{\circ} 06.3^{\prime} \mathrm{W}$.

Occurrence of zone: Discontinuously cored at Sites 266, 267, and 269 .

Correlation: In Eltanin piston core 13-17 the Mesocena diodon Zone is present throughout the Gilbert magnetic epoch below the base of event "c" (4.41 m.y.B.P.) and in the normally magnetized basal 2 meters of the core which is probably equivalent to the late Miocene Epoch 5 magnetic epoch (5.10 m.y.B.P.). The base of the zone is unrepresented in the present study.

\section{Mesocena circulus Zone}

Top: First consistent occurrence of Mesocena diodon. Last consistent occurrence of Mesocena circulus.
Base: First consistent occurrence of Mesocena circulus. Last consistent occurrence of D. mutabilis.

Age: Late Miocene.

Important characteristics of the zonal assemblage: This zone is characterized by the consistent meager to common occurrence of the named taxon in conjunction with rare to few Dictyocha aspera, Mesocena diodon, Distephanus speculum var. pentagonus, and D. speculum s.l.

Reference section: Site $274: 68^{\circ} 59.81^{\prime} \mathrm{S}, 173^{\circ} 25.64^{\prime} \mathrm{E}$.

Occurrence of zone: Continuously cored at Sites 266 and 274 and possibly represented at Site 267.

Correlation: Broadly equivalent to the Mesocena circulus var. apiculata Zone of Ling (1973) and includes part of the calcareous nannofossil Discoaster quinqueramus (NN11) and Ceratolithus tricorniculatus (NN12) zones of Worsley (1973).

Remarks: The assemblages of this zone are of particularly low abundance and diversity. The poor preservation of the assemblage suggests that some abundance and diversity diminution may be partially the result of dissolution.

\section{Dictyocha mutabilis Zone}

Top: Last occurrence of Dictyocha mutabilis.

Base: First occurrence of Dictyocha mutabilis.

Age: Early middle Miocene.

Important characteristics of the zonal assemblage: The silicoflagellate assemblage of this zone is particularly sparse with only rare occurrences of Distephanus longispinus, D. cf. longispinus, and D. boliviensis var. major.

Reference section: Site $266: 56^{\circ} 24.13^{\prime} \mathrm{S}, 110^{\circ} 06.70^{\prime} \mathrm{E}$.

Occurrence of zone: Site 266, Sections 4-6. The base of this zone may not be present at the base of Core 13 but, instead, in the uncored interval between Cores 13 and 14.

Correlation: At Site 266 this zone is broadly equivalent to the calcareous nannofossil Discoaster exilis (NN6) Zone of Martini (1971). The occurrence of the present species in the middle Miocene (Helvetian) of San Pedro, California (Deflandre, 1950c) may also be correlative.

\section{Distephanus longispinus Zone}

Top: First occurrence of Dictyocha mutabilus.

Base: Last consistent occurrence of Corbisema triacantha.

Age: Early middle Miocene-middle middle Miocene.

Important characteristics of the zonal assemblage: Silicoflagellate abundance and diversity are particularly low throughout the entire zone. The most consistently occurring species are Distephanus longispinus, D. cf. longispinus, D. crux, and D. speculum s.l. Rarer occurrences of Distephanus speculum var. pentagonus, Dictyocha aspera, D. fibula, and Cannopilus hemisphericus were noted.

Reference section: Site $266: 56^{\circ} 24.13^{\prime} \mathrm{S}, 110^{\circ} 06.70^{\prime} \mathrm{E}$.

Occurrence of zone: Intermittently cored at Site 266 from Core 14 through Core 17, Section 3.

Correlation: At Site 266, the lower portion of this zone (Cores 16 and 17) is equivalent to the calcareous 
nannofossil Sphenolithus heteromorphus (NN5) Zone of Burns (this volume). The upper portion of the zone, in Cores 14 and 15, cannot be correlated to the standard nannoplankton zonation due to the paucity of calcareous nannofossils; however, this interval can be no older than the portion of the Discoaster exilis (NN6) Zone of Burns, which is present in Core 13.

\section{Corbisema triacantha Zone}

Top: The last consistent occurrence of Corbisema triacantha.

Base: The last occurrence of Naviculopsis navicula and $N$. regularis.

Age: Late early Miocene-Early middle Miocene.

Important characteristics of the zonal assemblage: This zone is characterized by the consistently meager to abundant occurrence of Corbisema triacantha in addition to lesser amounts of Distephanus longispinus, Cannopilus hemisphaericus, and C. sphaericus. Mesocena apiculata and D. cf. longispinus are present only in the lower portion of the zone. The sole stratigraphic appearance of Cannopilus antarcticus and an acme of Distephanus boliviensis var. major provide useful datums in the upper portion of the zone.

Reference section: Site $266: 59^{\circ} 24.13^{\prime} \mathrm{S}, 110^{\circ} 06.70^{\prime} \mathrm{E}$.

Occurrence of zone: Intermittently cored at Site 266, represented in Cores 17 and 18.

Correlation: The top of this zone has been previously described as occurring in the lower (?) to middle Miocene in the equatorial Pacific (Martini, 1971), in the calcareous nannofossil Discoaster exilis Zone (NN6) of the eastern equatorial Pacific (Bukry and Foster, 1973), and corresponding to the top of the calcareous nannofossil Sphenolithus heteromorphus (NN5) Zone in the eastern North Pacific (Bukry, 1973). In Italy and Majorca the $C$. triacantha Zone is broadly equivalent to the radiolarian Calocycletta costata Zone or Dorcadospyris alata Zone and the calcareous nannofossil Sphenolithus heteromorphus (NN5) Zone (Sanfilippo et al., 1973).

\section{Naviculopsis navicula Zone}

Top: Last occurrence of Naviculopsis navicula and Naviculopsis regularis.

Base: First consistent occurrence of Naviculopsis navicula.

Age: Late early Miocene.

Important characteristics of the zonal assemblage: This zone is characterized by the consistently common occurrence of Naviculopsis navicula, Distephanus cf. longispinus, D. crux, D. speculum, and Mesocena apiculata. Species found sporadically through the zone include: meager to common Corbisema triacantha and Naviculopsis regularis and meager Distephanus longispinus, Cannopilus hemisphaericus, and C. sphericus.

Reference section: Site $266: 56^{\circ} 24.13^{\prime} \mathrm{S}, 110^{\circ} 06.70^{\prime} \mathrm{E}$. 266.

Occurrence of zone: Discontinuously cored at Site

Correlation: At Site 266 this zone is equivalent to the calcareous nannofossil Sphenolithus belemnos (NN3) Zone of Burns (this volume). The only other occurrences of this zone are in Monte Calvo, Italy (Martini, 1972);
Casalino, Italy (Sanfilippo et al., 1973); and Ernstbrunn, Trafostation, Austria (Bachmann, 1970). Sanfilippo et al. (1973) suggest that the $N$. navicula Zone is correlative to the calcareous nannofossil Sphenolithus belemnos (NN3) Zone and upper Discoaster druggi (NN2) Zone and Martini (1972) also correlates this zone to the lower Calocycletta costata and upper Calocycletta virginis zones of the radiolarian zonation.

\section{Naviculopsis regularis Zone}

Top: First consistent occurrence of Naviculopsis navicula.

Base: Last common occurrence of Naviculopsis robusta.

Age: Middle early Miocene.

Important characteristics of the zonal assemblage: This zone is characterized by the consistently common to abundant occurrence of Naviculopsis regularis, Distephanus speculum s.l., D. cf. longispinus, and Mesocena apiculata. Other species occurring through the zone in meager to common quantities are Cannopilus hemisphaericus, Corbisema triacantha, Dictyocha fibula, $D$. staurodon, Distephanus crux, D. cf. longispinus, Mesocena oamaruensis, and Naviculopsis navicula var. naviculopsis. A few Naviculopsis navicula found only at the base of the zone represent the initial appearance of this species.

Reference section: Site $266: 56^{\circ} 24.13^{\prime} \mathrm{S}, 110^{\circ} 06.70^{\prime} \mathrm{E}$. Occurrence of zone: Discontinuously cored at Site 266.

Correlation: Equivalent to the calcareous nannofossil Discoaster druggi (NN2) Zone of Burns (this volume) at Site 266.

\section{Naviculopsis robusta Zone}

Top: Last consistent occurrence of Naviculopsis robusta.

Base: First consistent occurrence of Naviculopsis robusta.

Age: Early early Miocene.

Important characteristics of the zonal assemblage: This zone is characterized by consistent meager to abundant Naviculopsis robusta and $N$. regularis, meager Distephanus longispinus and meager to common Distephanus speculum. Species which occur sporadically through the zone include: meager Cannopilus hemisphaericus and Distephanus boliviensis; and meager to common Distephanus crux and D. cf. longispinus.

Reference section: Site $266: 56^{\circ} 24.13^{\prime} \mathrm{S}, 110^{\circ} 06.70^{\prime} \mathrm{E}$.

Occurrence of zone: Discontinuously cored at Site 266, Cores 22 and 23.

Correlation: Studies of Site 266 calcareous nannofossils (Burns, this volume) indicate that this zone is below the Discoaster druggi (NN2) Zone and still within the Miocene; thus the Naviculopsis robusta Zone appears to be equivalent to the Triquetrorhabdulus carinatus (NN1) Zone.

\section{Naviculopsis biapiculata Zone}

Top: Undefined.

Base: Last consistent common occurrence of Dictyocha deflandrei. 
Age: Late Oligocene.

Important characteristics of the zonal assemblage: This zone is characterized by the consistent common to abundant occurrence of Naviculopsis biapiculata and Distephanus crux. Other floral elements occurring less frequently include: Cannopilus sphericus, Corbisema archangelskiana, Dictyocha deflandrei, $D$. frenguellii, $D$. pentagona, Distephanus speculum s.l., D. speculum var. pentagonus, Mesocena apiculata, M. oamaruensis, Naviculopsis regularis, and $N$. trispinosa.

Reference section: Site $267: 59^{\circ} 15.74^{\prime} \mathrm{S}, 104^{\circ} 29.30^{\prime} \mathrm{E}$. Occurrence of zone: Site 267.

\section{Dictyocha deflandrei Zone}

Top: Last consistent occurrence of Dictyocha deflandrei.

Base: The first consistent common occurrence of Dictyocha deflandrei above the last common occurrence of Dictyocha hexacantha.

Age: Early Oligocene.

Important characteristics of the zonal assemblage: This zone is characterized by the consistently common to abundant occurrence of Mesocena apiculata, Dictyocha deflandrei s.l., Distephanus cf. D. boliviensis, D. crux s.l., and Corbisema apiculata. Other species occurring sporadically and in meager to common quantities are Corbisema hastata, C. triacantha, Dictyocha variabilus, Distephanus cf. D. speculum var. pentagonus, and Mesocena oamaruensis, Dictyocha frenguellii occurs abundantly throughout the upper portion of the zone and its evolutionary appearance has been utilized in establishing two subzones. The lower portion of the Dictyocha deflandrei Zone which contains common Mesocena apiculata and lacks Dictyocha frenguellii is designated as the Mesocena apiculata Subzone, and the portion of the zone that is characterized by the consistent common to abundant occurrence of Dictyocha frenguellii is designated as the $D$. frenguellii Subzone.

Reference section: Site 274: $68^{\circ} 59.81^{\prime} \mathrm{S}, 173^{\circ} 25.64^{\prime} \mathrm{E}$. Occurrence of zone: Continuously cored at Site 274 .

\section{SILICOFLAGELLATES AT EACH SITE}

Silicoflagellate abundances and diversities were extremely low at Sites 264, 271, 272, and 273; information on their occurrence is contained in the site summaries. The occurrences of silicoflagellates, zonal subdivisions, and geologic ages are tabulated for Sites 266, 267, 269, and 274. All tables (Tables 3-6) contain the following information about each sample studied: (1) core number, section number, interval $(\mathrm{cm})$, and depth below sea floor (m) in columns on the left; (2) an alphabetically arranged list of silicoflagellates with quantitative representation of abundances; (3) zones and geological ages at the right of each table. Diagonal lines in a zonal column indicate stratigraphic sections where zonation was impossible due to the lack of diagnostic silicoflagellates or unrecovered sediment. When zonal boundaries occur in coring gaps, they are positioned midway between recovered sections.

\section{Site 264}

$\left(34^{\circ} 58.13^{\prime} \mathrm{S}, 112^{\circ} 02.68^{\prime} \mathrm{E}\right.$ ', water depth $2876 \mathrm{~m}$ )

Site 264 is located near the central-southern edge of the Naturaliste Plateau, about $125 \mathrm{~km}$ southwest of Leg 26 Site 258 . Two holes were drilled at the site which penetrated a 167-meter (14 core) sedimentary sequence composed entirely of pelagic carbonate sediment.

Core-catcher samples from all 14 recovered cores were examined for silicoflagellates and all were found to be barren, with the exception of Core 2, obtained from 25.5 to 35 meters. Examination of several Core 2 corecatcher slide preparations yielded specimen counts of not more than five per slide. Silicoflagellates identified include: Naviculopsis biapiculata, Naviculopsis constricta, Corbisema archangelskiana, and Mesocena oamaruensis var. quadrangula. These species can occur concurrently in either the upper Oligocene or the upper Eocene, but a late Eocene age for Sample 2, CC is favored on the basis of calcareous nannoplankton and foraminiferal biostratigraphic evidence.

\section{Site 266}

$\left(56^{\circ} 24.13^{\prime} \mathrm{S}, 110^{\circ} 06.70^{\prime} \mathrm{E}\right.$, water depth $\left.4173 \mathrm{~m}\right)$

Site 266 is located on the southern flank of the Southeast Indian Ridge about $800 \mathrm{~km}$ from the ridge crest. Intermittent coring of 370 meters of sediment was accomplished before basement was encountered. The sediment sequence is comprised of three main units: an upper unit, from 0 to 148 meters, composed of diatom ooze and clay diatom ooze; a middle unit, at 148 to 253 meters, composed of mixed nanno ooze and clay and diatom ooze and clay; and a lower unit, from 253 to 370 meters, predominantly composed of nanno clay.

Many of the middle and early Miocene silicoflagellate zones at this site have been related to previously described calcareous nannofossil zones. For this reason, early and middle Miocene silicoflagellate zones have had their reference sections established at this site.

Sample 1, 110-112 cm, at 1 meter, through Sample 4$3,100-102 \mathrm{~cm}$, at 67 meters, contain an abundant, wellpreserved silicoflagellate assemblage of limited diversity. The floral assemblage is characterized by the consistently common occurrence of long- and short-spined Distephanus speculum and is therefore conformable with the $D$. speculum Zone A. Species occurring sporadically and in meager amounts include $D$. speculum var. pentagonus, $D$. sp. cf. boliviensis, Dictyocha pseudofibula, $D$. medusa, D. aspera, and D. fibula. In Sample 4-2, 60-62 $\mathrm{cm}$, at 68 meters, the acme of Distephanus polyactis provides a usable datum within the lower portion of the Distephanus speculum Zone A.

Thirteen samples examined between Sample 4-4, 120 $122 \mathrm{~cm}$ and Sample 6-6, 120-122 cm, obtained from 68 to 110 meters, contain abundant silicoflagellates and are assigned to the $D$. speculum Zone B. The samples are characterized by the consistent occurrence of abundant short-spined $D$. speculum and the sporadic, meager to common occurrence of long-spined $D$. speculum. Species occurring sporadically through this interval include those previously described in the $D$. speculum Zone A, as 
TABLE $3 \mathrm{~A}$

Distribution of Silicoflagellates at Site 266

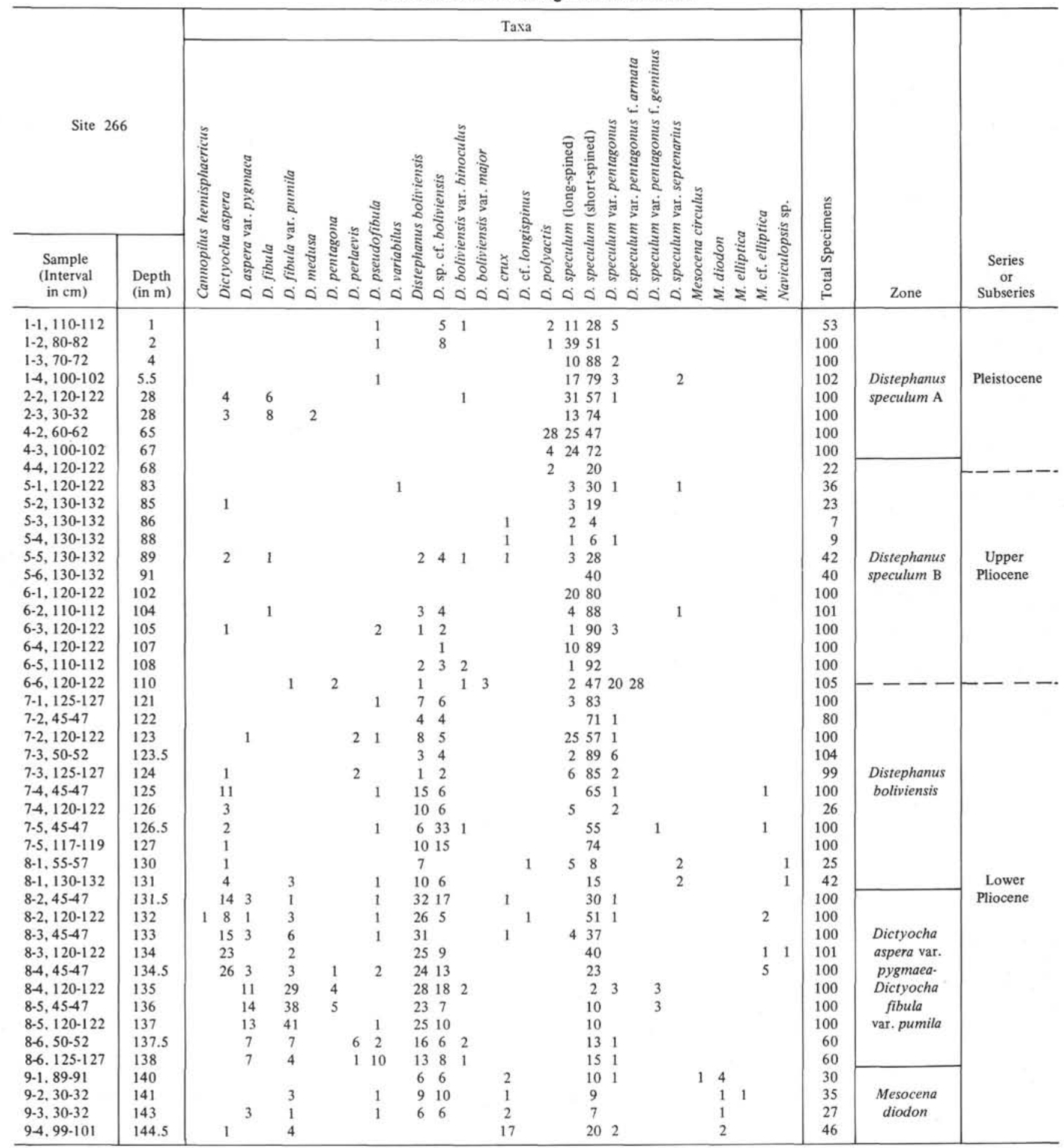


TABLE 3B

Distribution of Silicoflagellates at Site 266

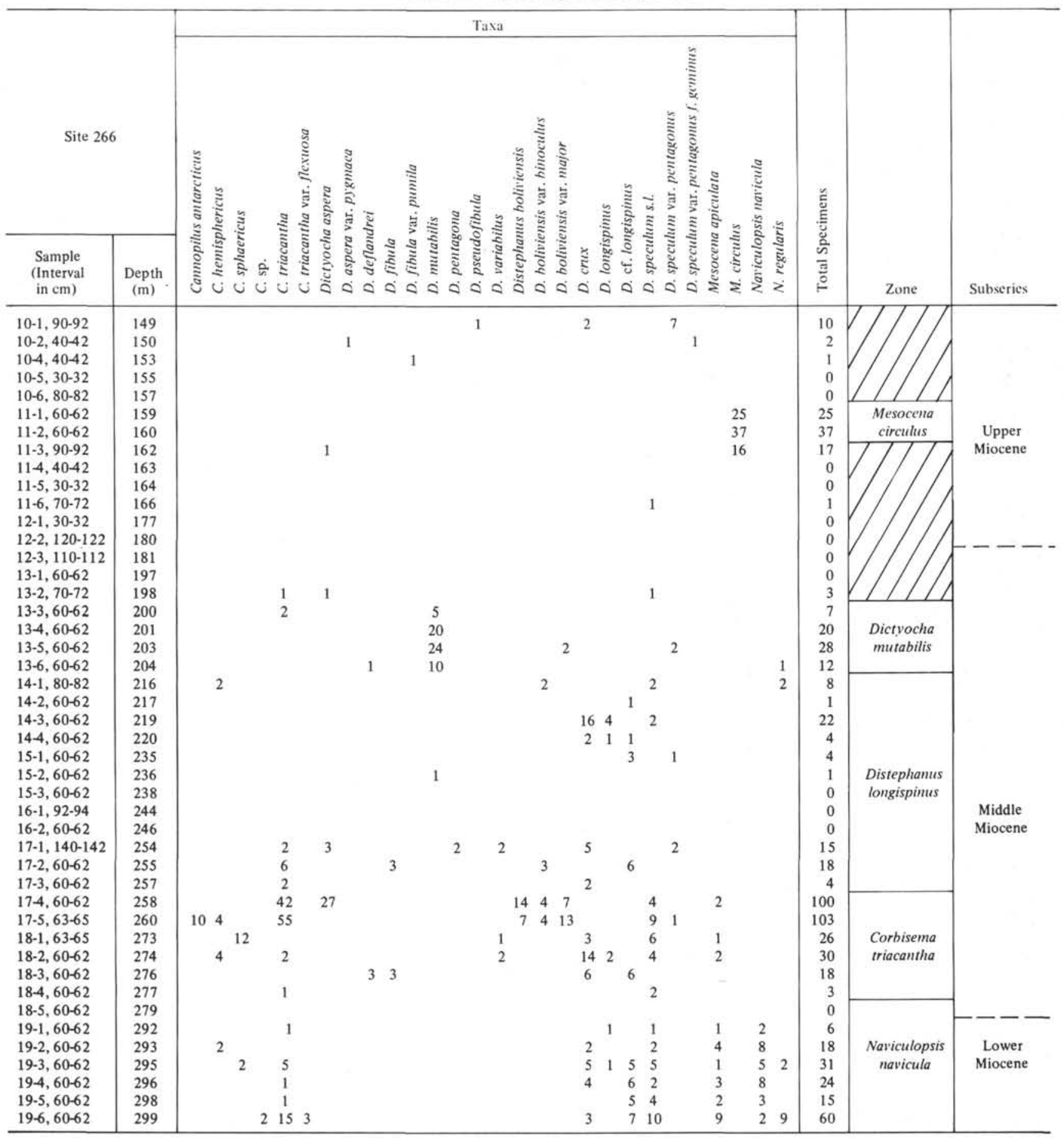


TABLE 3C

Distribution of Silicoflagellates at Site 266

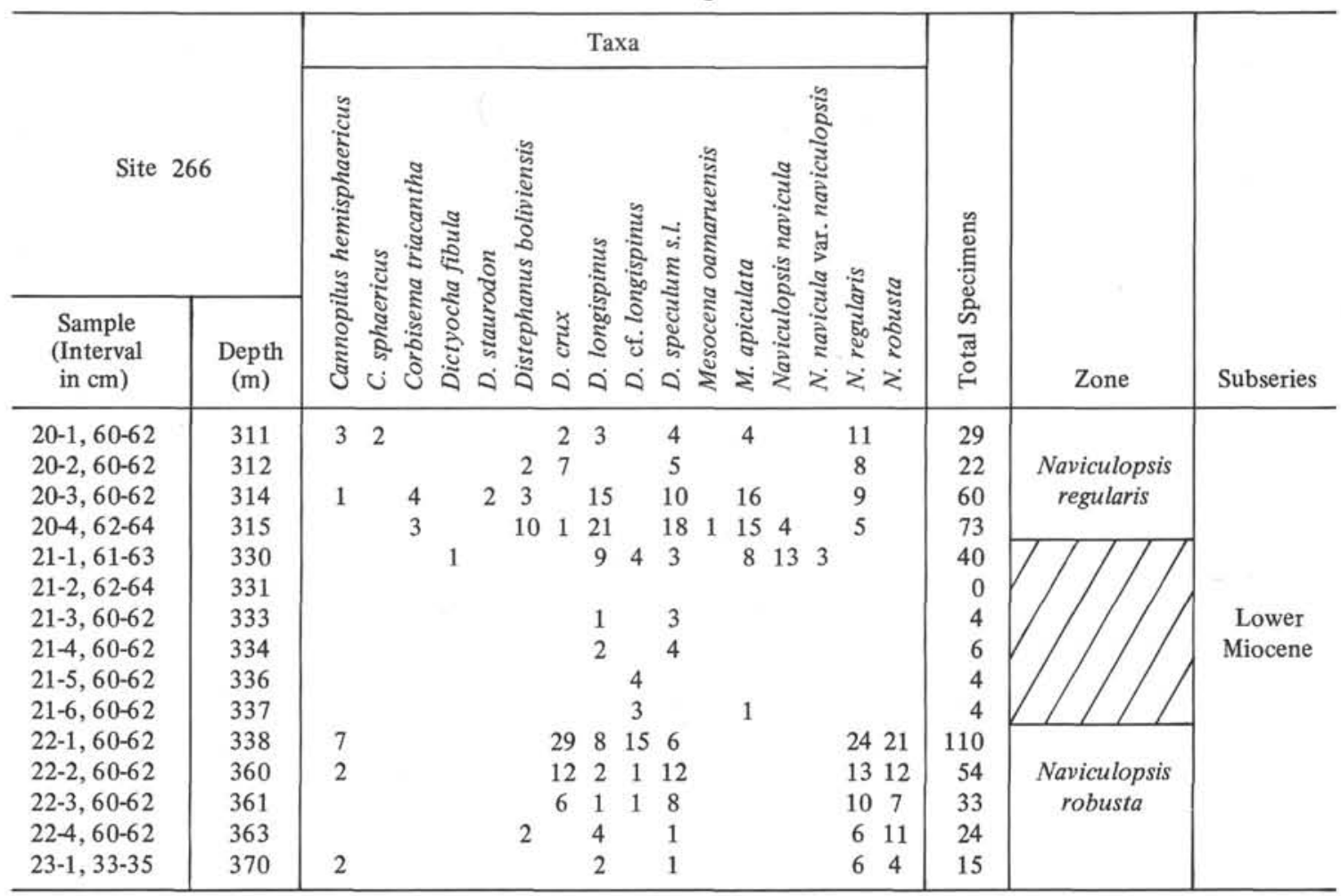

well as meager $D$. boliviensis and $D$. boliviensis var. major. The acme of Distephanus speculum var. pentagonus and $D$. speculum var. pentagonus forma armatus, at 108 meters, provides an easily recognizable datum within the lower D. speculum Zone B.

Sample 7-1, 125-127 cm through Sample 8-1, 130-132 $\mathrm{cm}$, from 121 to 131 meters, is characterized by the consistently common occurrence of Distephanus boliviensis and therefore conforms to the zone bearing the same name. The portion of this interval below Sample 7-3, $125-127 \mathrm{~cm}$, contains the uppermost range of consistently occurring Dictyocha aspera and is correlated to the Gilbert magnetic epoch above Gilbert " $a$ " (3.72-3.32 m.y.B.P.).

Sample 8-2, 45-47 cm through Sample 9-4, 99-101 cm, from 131.5 to 144.5 meters, contains an almost temperate assemblage of silicoflagellates which includes the following warm-water species: Dictyocha aspera, $D$. aspera var. pygmaea, D. fibula, D. fibula var. pumila, D. pentagona, D. perlaevis, and D. pseudofibula.

Of five samples examined from Core 10, from 149 to 157 meters, only one sample $(10-1,90-92 \mathrm{~cm})$ contained silicoflagellates. No zonal assignment was possible.

Core 11, Sections 1-3, from 159 to 163 meters, contains common to abundant Mesocena circulus and is referred to the zone bearing the same name. A barren interval is present throughout the remainder of Core 11, in all of Core 12 and in Core 13 above Section 2, 70-72 cm. This interval contains only fragments of unidentifiable silicoflagellates. The significance of this and other barren intervals is discussed in the paleoenvironmental portion of the text.
The Dictyocha mutabilis Zone occurs in Core 13, between Section 3, 60-62 cm and Section 6, 60-62 cm, at 198 to 204 meters. Cores 14, 15, 16 and Core 17 above Section 4, 60-62 cm, are referred to the Distephanus longispinus Zone of the middle Miocene. The interval between Sample 17-4, 60-62 cm and Sample 18-5, 60-62 $\mathrm{cm}$, from 258 to 279 meters, conforms to the Corbisema triacantha Zone. Core 19, from 292 to 299 meters, and Core 20 , at 311 to 315 meters, are referred to the Naviculopsis navicula and $N$. regularis zones, respectively. Core 21, obtained from 330 to 337 meters, contains insufficient age-diagnostic silicoflagellates for a zonal designation. Core 21 through Sample 23-1, 33-35 cm, at 338 to 370 meters, is referred to the $N$. robusta Zone.

\section{Site $\mathbf{2 6 7}$}

(Holes 267, 267A: $59^{\circ} 15.74^{\prime} \mathrm{S}, 1^{\circ} 4^{\circ} 29.30^{\prime} \mathrm{E}$, water depth $4564 \mathrm{~m}$;

Hole 267B: $29^{\circ} 14.55^{\prime} \mathrm{S}, 104^{\circ} 29.94^{\prime} \mathrm{E}$, water depth $4539 \mathrm{~m}$ )

Site 267 is located in the deep basin south of the Southeast Indian Ridge and about $600 \mathrm{~km}$ north of the Wilkes Land continental shelf. Three holes $(267,267 \mathrm{~A}$, and 267B) were discontinuously cored at two locations $2.6 \mathrm{~km}$ apart. The sedimentary sequence in Holes 267 and $267 \mathrm{~A}$ is comprised of two units; an upper unit of clay, silty clay, and clay diatom ooze which is approximately 110 meters thick; and a lower, 97-meter-thick unit of nanno ooze, chalk, and micritic limestone. The sedimentary sequence at Hole 267B is also comprised of two lithologic units; an upper unit similar to that of the 


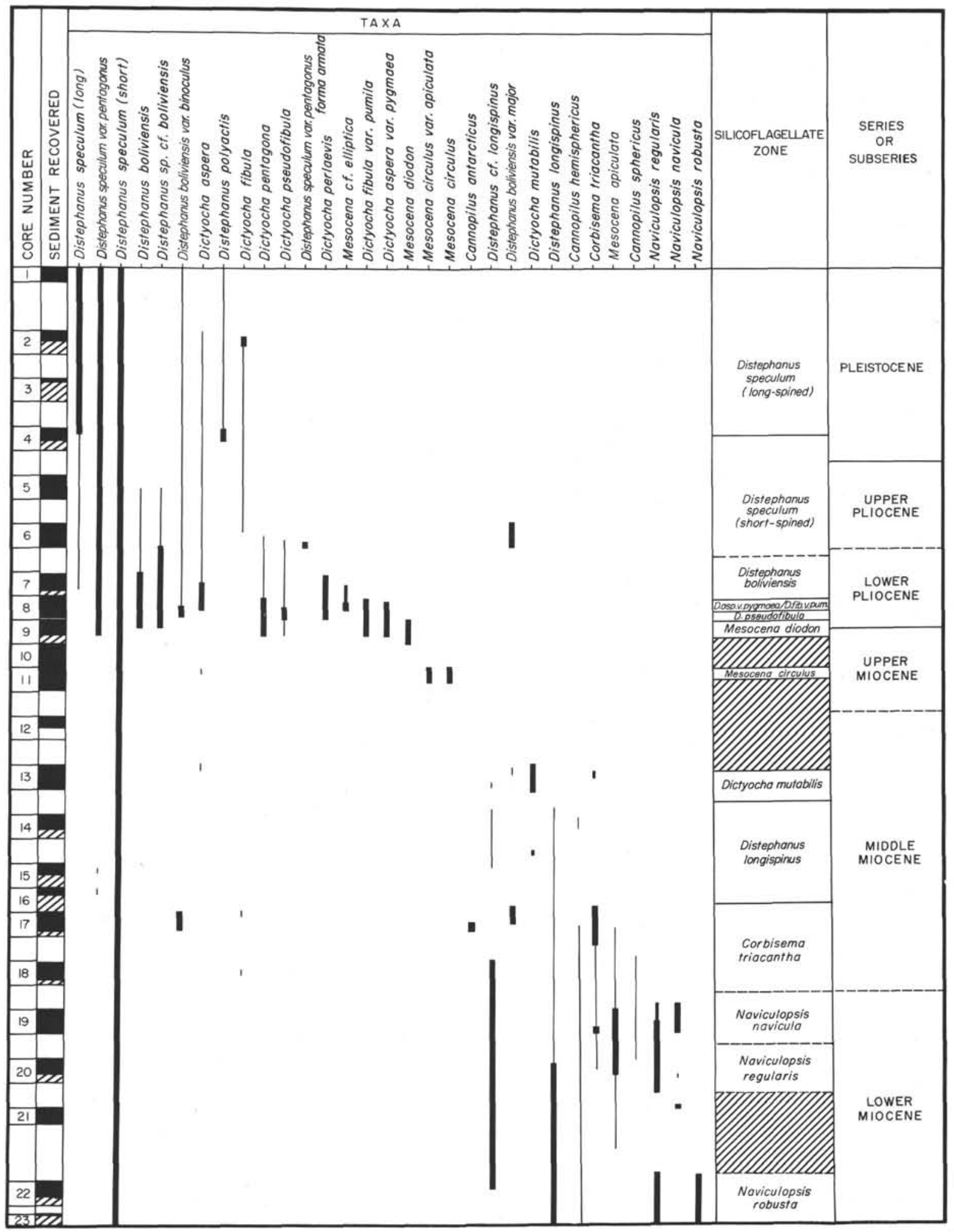

Figure 3. Ranges of selected silicoflagellates at Site 266 with zones and site geologic series and subseries.

other two holes, but 310 meters thick and a lower, 10meter-thick nanno chalk.

Sample 1-6, 0-2 cm, obtained at 11.5 meters, contains abundant, well-preserved silicoflagellates which conform to the Distephanus speculum Zone A. A meager number of reworked specimens were observed from the older D. speculum Zone B or D. boliviensis Zone.

Sample 1A-6, 120-122 cm through Sample 1A, CC, at 13 to 13.5 meters, contain a mixed assemblage of Pleistocene and Pliocene silicoflagellates. A large 
TABLE 4

Distribution of Silicoflagellates at Site 267

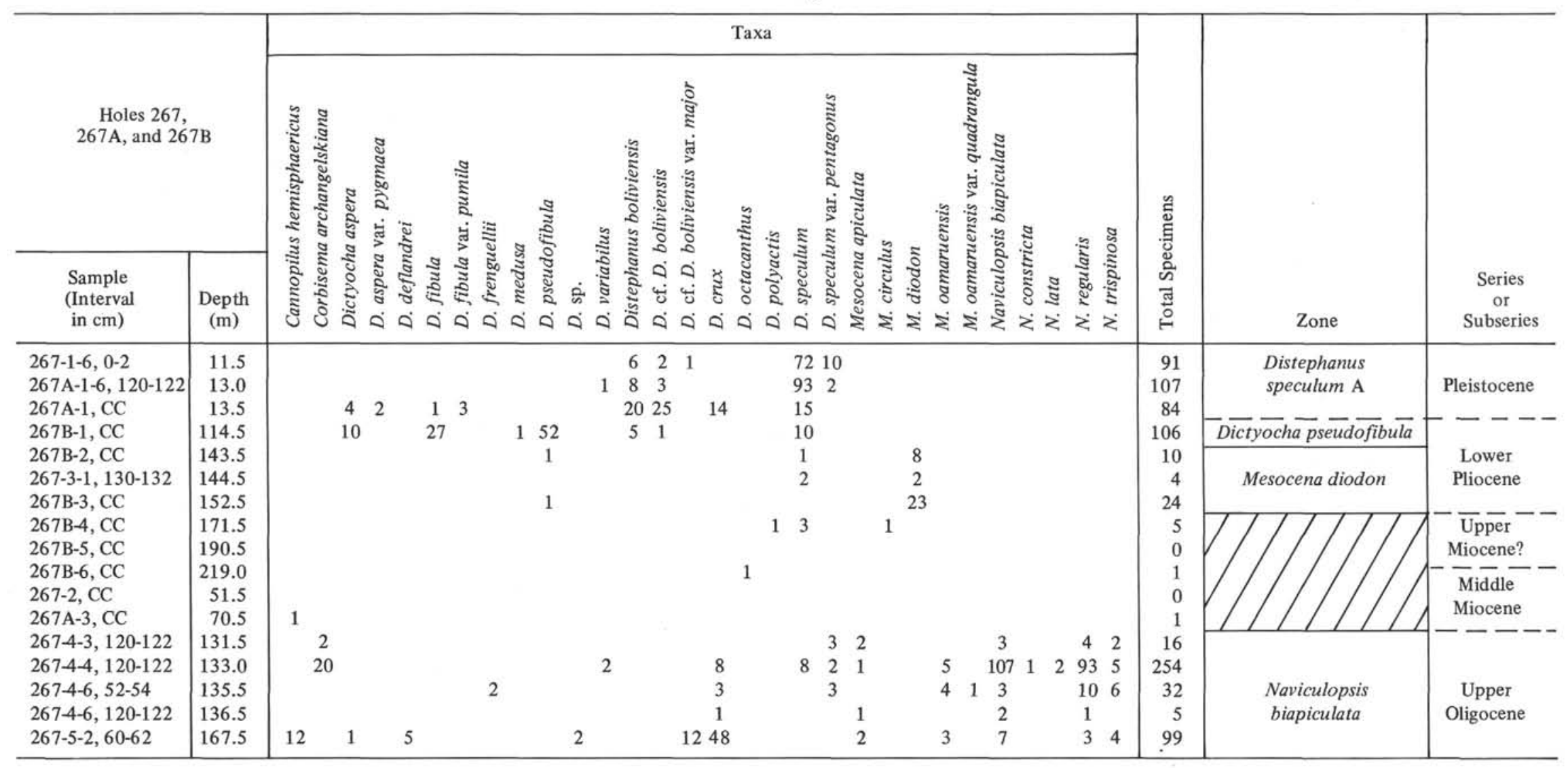


TABLE 5

Distribution of Silicoflagellates at Site 269

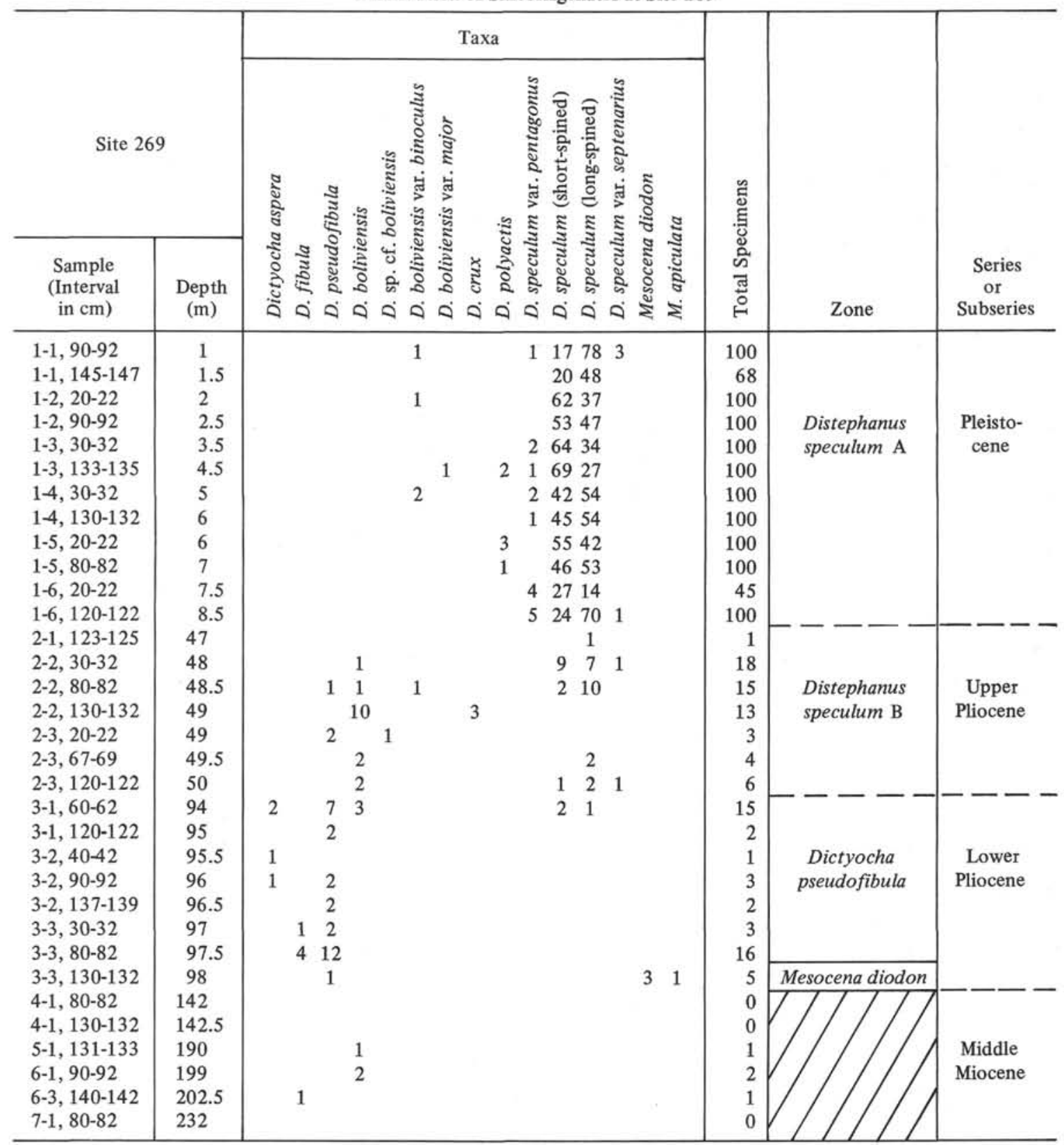

percentage of long-spined $D$. speculum is the sole criterion for assignment of this interval to the $D$. speculum Zone A.

Samples $1 \mathrm{~A}, \mathrm{CC}$ and $2, \mathrm{CC}$ are barren of silicoflagellates.

Sample 1B, CC, at 114.5 meters, contains an abundant and moderately diverse assemblage. The abundant occurrence of Dictyocha fibula, D. aspera, and $D$. pseudofibula indicates, with a high degree of reliability, that the assemblage conforms to the early Pliocene Dictyocha pseudofibula Zone. Approximately $90 \%$ of the assemblage is comprised of warm-water Dictyocha species, thereby indicating early Pliocene surface water temperatures in excess of $12^{\circ} \mathrm{C}$ (see text on early Pliocene paleotemperatures).
The interval between the Samples 2B, CC and 3B, CC, from 143 to 152.5 meters, contains a meager but wellpreserved assemblage of rare Dictyocha pseudofibula, Distephanus cf. D. boliviensis, and common Mesocena diodon. The assemblage conforms to the $M$. diodon Zone.

Sample 4B, CC at 171.5 meters, yielded only three specimens of Distephanus speculum and one specimen of D. polyactis and Mesocena circulus. Insufficient information exists for zonal designation; however, the restriction of Mesocena circulus to the upper Miocene in the Southern Ocean suggests a late Miocene age for this sample.

Sample 5B, CC is barren of silicoflagellates, and Sample $6 \mathrm{~B}, \mathrm{CC}$ contains only a single specimen of 
TABLE 6A

Distribution of Silicoflagellates at Site 274

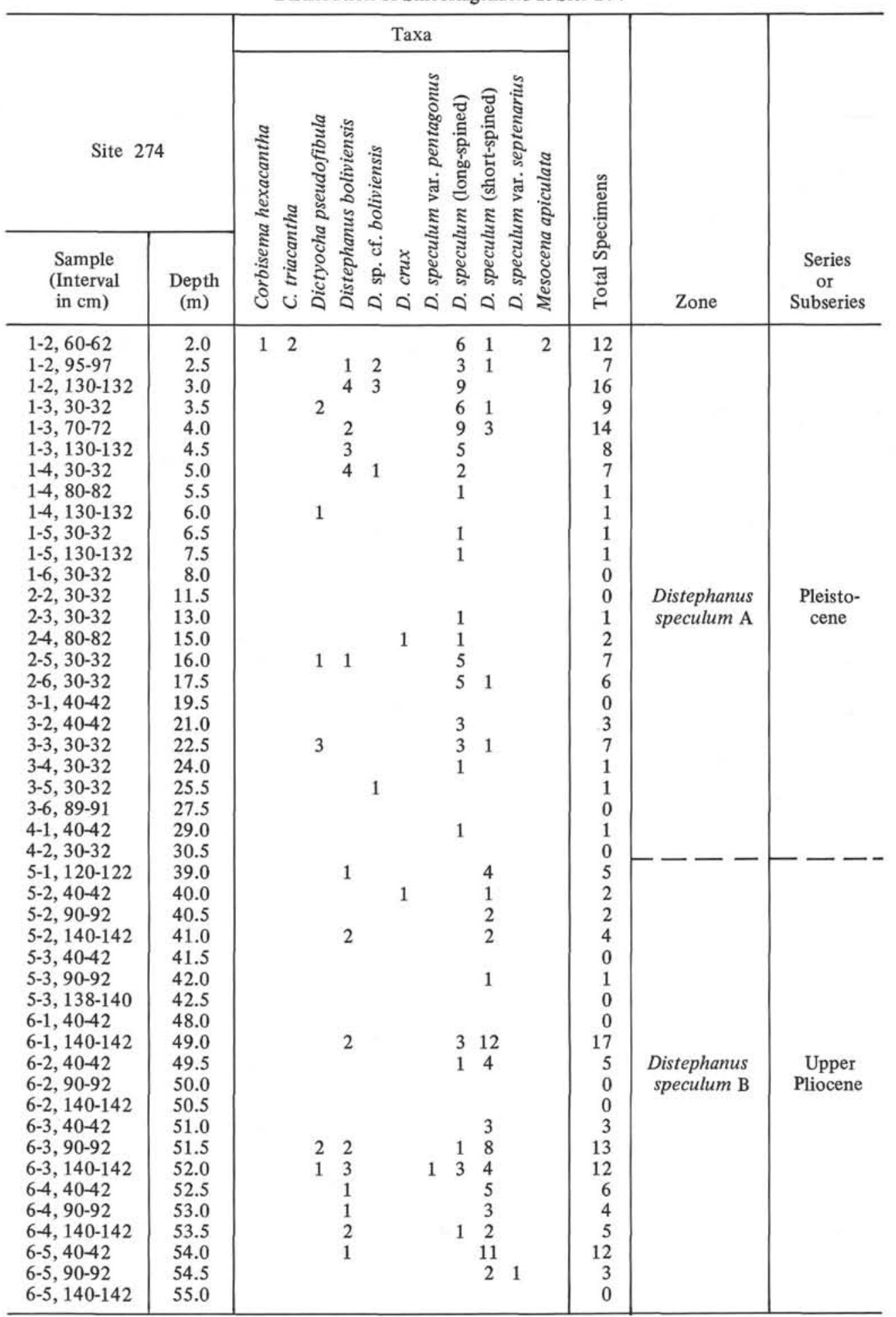


TABLE 6B

Distribution of Silicoflagellates at Site 274

\begin{tabular}{|c|c|c|c|c|c|c|c|c|c|c|c|c|c|c|c|}
\hline \multirow{2}{*}{\multicolumn{2}{|c|}{ Site 274}} & \multicolumn{11}{|c|}{ Taxa } & \multirow{3}{*}{ 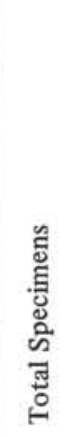 } & \multirow[b]{3}{*}{ Zone } & \multirow[b]{3}{*}{ Subseries } \\
\hline & & \multirow{2}{*}{ 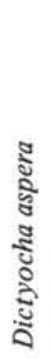 } & \multirow{2}{*}{ 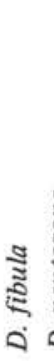 } & \multirow{2}{*}{ 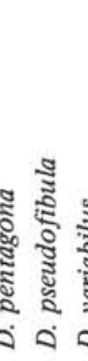 } & \multirow{2}{*}{ 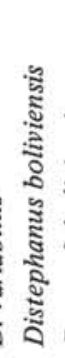 } & & \multirow{2}{*}{ 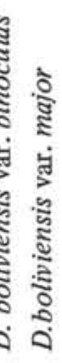 } & \multirow{2}{*}{\multicolumn{2}{|c|}{ 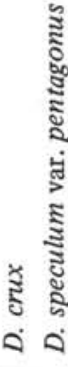 }} & \multirow{2}{*}{ 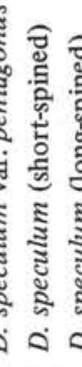 } & & \multirow{2}{*}{ 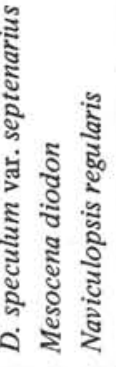 } & & & \\
\hline $\begin{array}{l}\text { Sample } \\
\text { (Interval } \\
\text { in } \mathrm{cm} \text { ) }\end{array}$ & $\begin{array}{l}\text { Depth } \\
\text { (m) }\end{array}$ & & & & & & & & & & & & & & \\
\hline $6-6,40-42$ & 55.5 & & & & & & & & & & & & 0 & \multirow{25}{*}{$\begin{array}{l}\text { Distephanus } \\
\text { speculum B }\end{array}$} & \multirow{8}{*}{$\begin{array}{c}\text { Upper } \\
\text { Pliocene }\end{array}$} \\
\hline $6-6,90-92$ & 56.0 & & & & & & & & & & & & 0 & & \\
\hline $6-6,140-142$ & 56.5 & & & & 1 & & & & & 2 & & & 3 & & \\
\hline $7-1,40-42$ & 57.5 & & & & & & & & & 3 & & & 3 & & \\
\hline $7-1,90-92$ & 58.0 & & & & 1 & & & & & 3 & 1 & & 5 & & \\
\hline $7-1,140-142$ & 58.5 & & & & 1 & 1 & & & & 1 & & & 3 & & \\
\hline $7-2,40-42$ & 59.0 & & & & 1 & & & & & 13 & 3 & & 17 & & \\
\hline $7-2,90-92$ & 59.5 & & & & 1 & & & & & 3 & & & 4 & & \\
\hline $9-1,40-42$ & 76.5 & & & 2 & & & & & & 11 & 2 & & 15 & & - \\
\hline $9-1,92-94$ & 77.0 & & & & 4 & 2 & & 1 & 3 & 10 & 3 & & 23 & & \\
\hline $9-1,140-142$ & 77.5 & & & & & & 2 & 1 & & 8 & 0 & & 11 & & \\
\hline $9-2,40-42$ & 78.0 & & & & 1 & & & & & 14 & 22 & 2 & 19 & & \\
\hline $9-2,90-92$ & 78.5 & & & & & & & & & 3 & & 1 & 4 & & \\
\hline $9-2,140-142$ & 79.0 & & & & 2 & & & & & & & & 2 & & \\
\hline $9-3,40-42$ & 79.5 & & & & 1 & & & & & 2 & & & 3 & & \\
\hline $9-3,80-82$ & 80.0 & & & & & & & & & 7 & 12 & 2 & 10 & & \\
\hline $9-3,110-112$ & 80.0 & & & & 1 & & & & & 3 & & & 4 & & \\
\hline $9-4,40-42$ & 81.0 & & & & 2 & & & & & 2 & & & 4 & & \\
\hline $9-4,140-142$ & 82.0 & & & 3 & 3 & & & & & 82 & 21 & 1 & 17 & & \\
\hline $9-5,40-42$ & 82.5 & & & 4 & 3 & & & & & 91 & 11 & 1 & 18 & & \\
\hline $9-5,90-92$ & 83.0 & & & & & & & & & 6 & & & 6 & & \\
\hline $9-5,140-142$ & 83.5 & & & & 1 & & & & & 6 & & & 7 & & \\
\hline $9-6,40-42$ & 84.0 & & & & 1 & & & & & 71 & 11 & 1 & 10 & & \\
\hline $9-6,90-92$ & 84.5 & & & & 1 & & & & & 12 & & 2 & 15 & & \\
\hline $9-6,140-142$ & 85.0 & & & & 2 & & & & & 14 & & 1 & 17 & & \\
\hline $10-1,90-92$ & 86.5 & & & 4 & 40 & & & & 8 & 20 & 63 & 3 & 100 & & \\
\hline $10-1,140-142$ & 87.0 & & & & 4 & 2 & & & 1 & 6 & & & 13 & & Lower \\
\hline $10-2,40-42$ & 87.5 & & & & 10 & 4 & & & & & & & 14 & & Pliocene \\
\hline $10-2,90-92$ & 88.0 & 1 & & 1 & 17 & 6 & 11 & & 1 & & & & 28 & & \\
\hline $10-2,140-142$ & 88.5 & & & & 13 & 5 & 11 & & 1 & & & & 21 & & \\
\hline $10-3,40-42$ & 89.0 & 2 & & 1 & 30 & 5 & 1 & & 1 & & & & 40 & & \\
\hline $10-3,93-95$ & 89.5 & & & 1 & 23 & 15 & 2 & & 1 & & & & 42 & & \\
\hline $10-3,140-142$ & 90.0 & 1 & & & 11 & 3 & & & & & & & 15 & Distephanus & \\
\hline $10-4,40-42$ & 90.5 & & & 1 & 12 & 4 & & & & & & & 17 & boliviensis & \\
\hline $10-4,90-92$ & 91.0 & & & & 15 & 5 & 11 & & & & & & 22 & & \\
\hline $10-4,140-142$ & 91.5 & & & & 5 & 2 & & & 1 & & & & 8 & & \\
\hline $10-5,40-42$ & 92.0 & & 1 & & 4 & & & & 1 & & & & 6 & & \\
\hline $10-5,90-92$ & 92.5 & 5 & & 2 & & & & & 2 & & & & 9 & & \\
\hline $10-5,140-142$ & 93.0 & 1 & & 1 & 2 & 2 & & 1 & & & & & 7 & & \\
\hline $10-6,40-42$ & 93.5 & & & & 9 & 5 & & 8 & & & & 1 & 23 & & \\
\hline $10-6,90-92$ & 94.0 & & & 6 & 13 & 3 & & 7 & & & & & 29 & & \\
\hline $10-6,140-142$ & 94.5 & & & 12 & 5 & 3 & & & & & & & 20 & & \\
\hline $11-1,140-142$ & 96.5 & & 1 & 9 & 2 & 10 & 2 & 3 & & & & & 27 & & \\
\hline $11-2,40-42$ & 97.0 & & & 39 & 2 & 3 & & & & 2 & & & 46 & Dictyocha & \\
\hline $11-2,90-92$ & 97.5 & & & 19 & 2 & 1 & & & & 1 & & & 23 & pseudofibula & \\
\hline $11-2,130-132$ & 98.0 & & & 38 & 2 & 1 & & 1 & 1 & 2 & & 1 & 46 & & \\
\hline
\end{tabular}


TABLE $6 \mathrm{C}$

Distribution of Silicoflagellates at Site 274

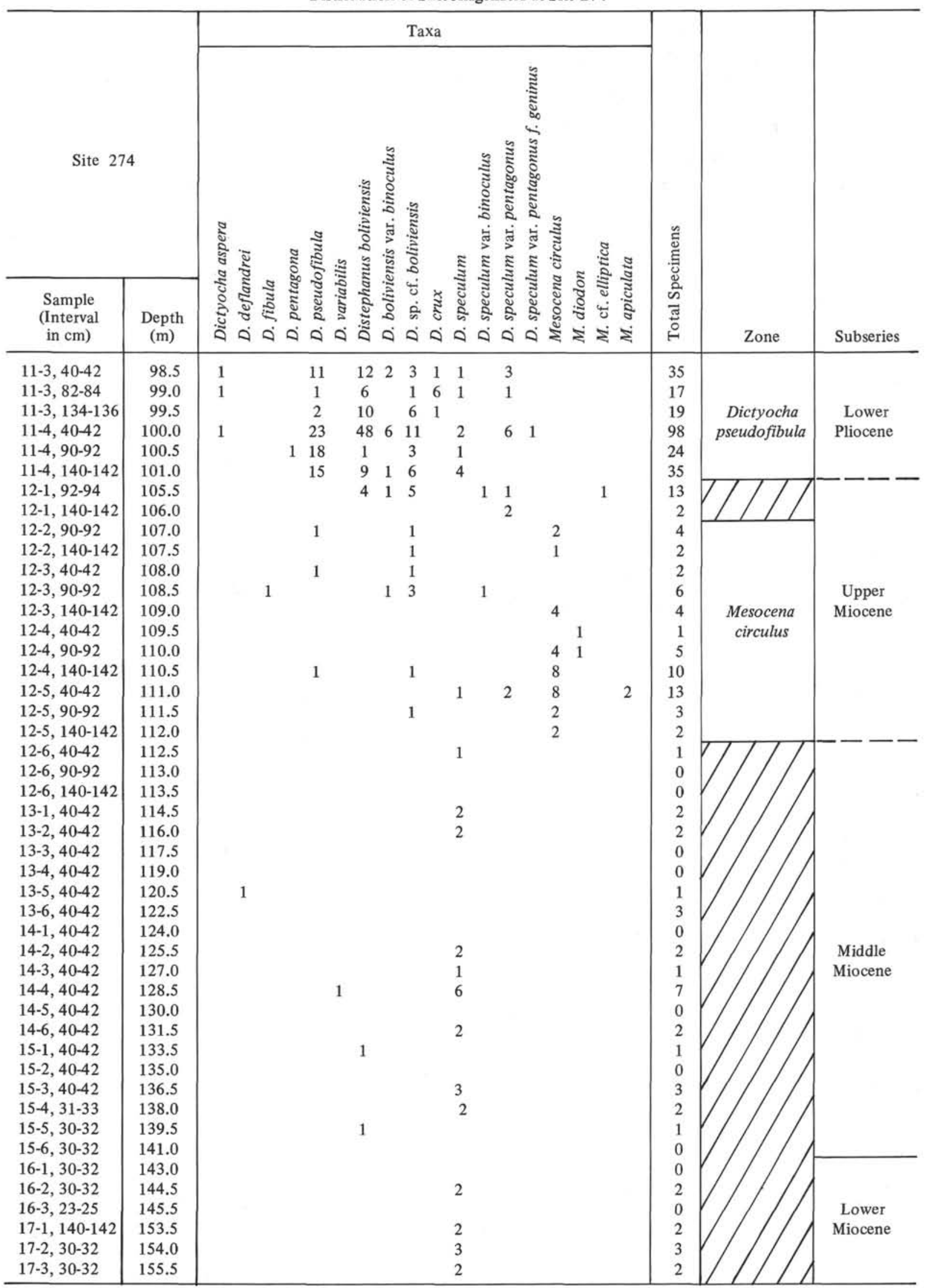


TABLE 6D

Distribution of Silicoflagellates at Site 274

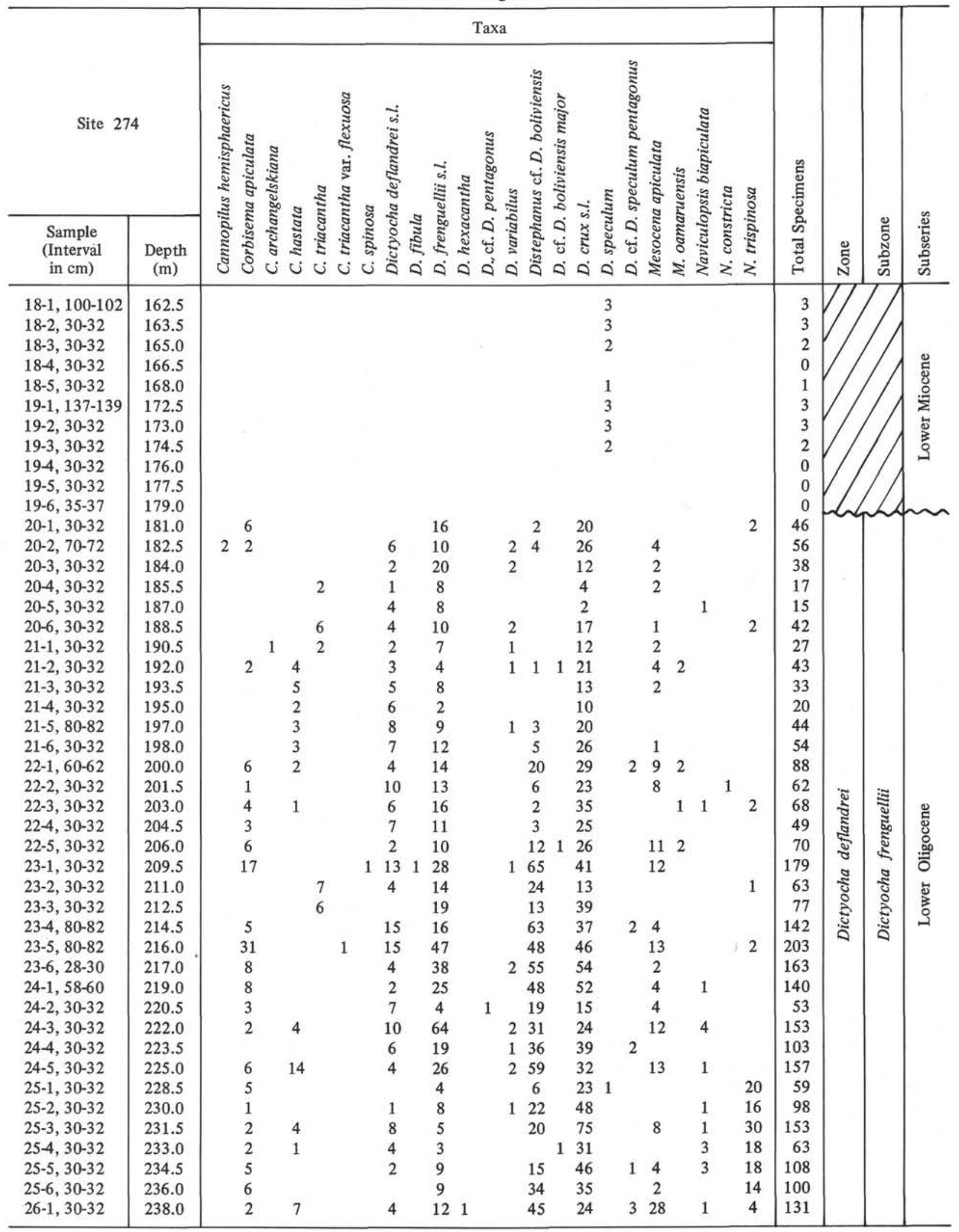


TABLE 6E

Distribution of Silicoflagellates at Site $\mathbf{2 7 4}$

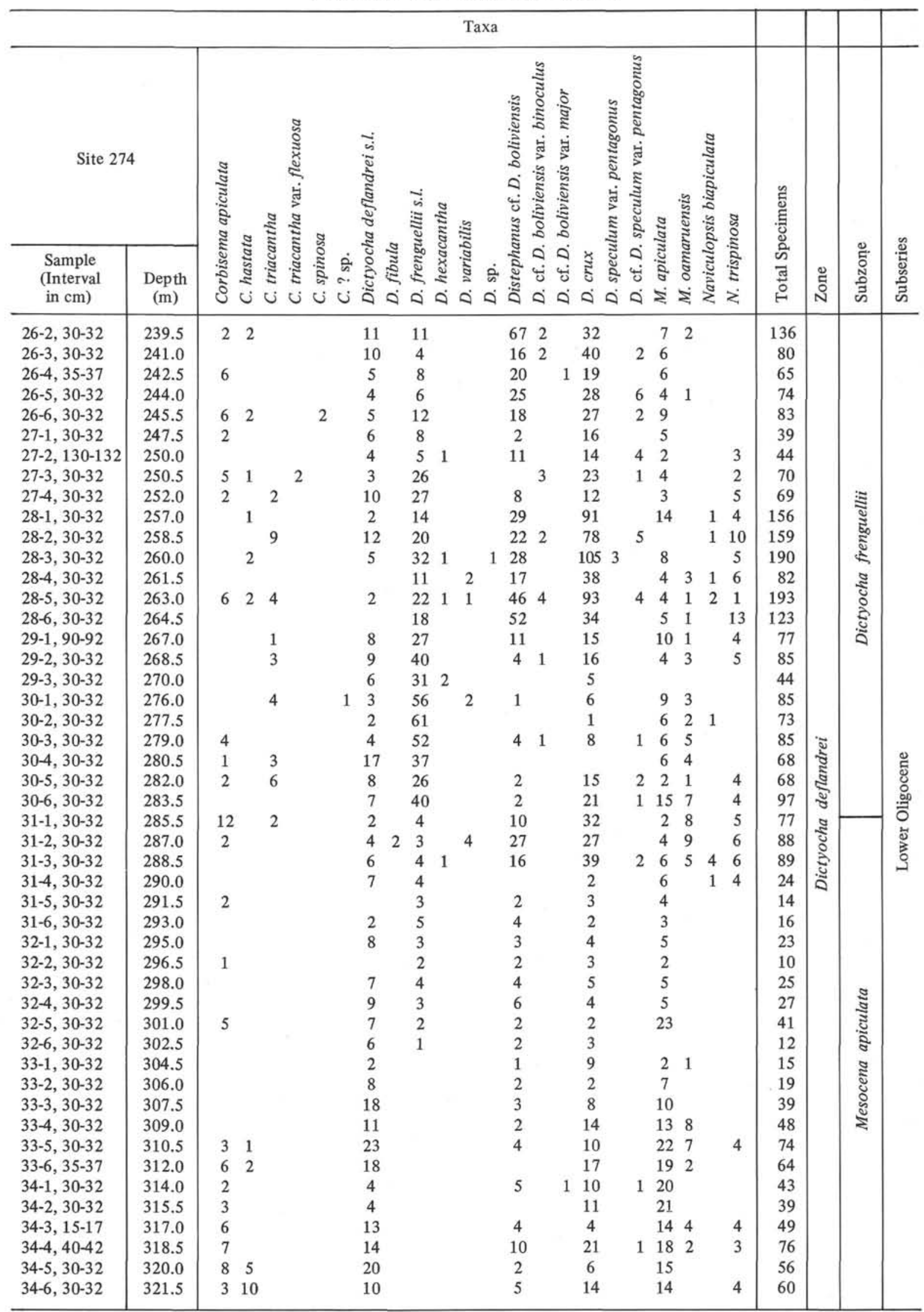


Distephanus octacanthus, which suggests a middle Miocene age for the sample.

Four samples examined between Sample 4-3, 120-122 $\mathrm{cm}$ and Sample 4-6, 52-54 cm, at 131.5 to 136.5 meters, contain a moderately well-preserved floral assemblage of modest diversity and abundance. All four samples are characterized by the presence of meager to abundant Distephanus crux, Naviculopsis biapiculata, N. regularis, $N$. trispinosa, and $N$. cf. lata. This first common occurrence of $N$. biapiculata, following the decline of Dictyocha deflandrei and $D$. frenguellii, suggests that this assemblage conforms to the upper Oligocene $N$. biapiculata Zone. The diatom Coscinodiscus vigilans, which has its Antarctic acme of occurrence in the early Miocene and late Oligocene (McCollum, personal communication), is abundant in these samples. Absent from the examined samples is Rocella gemma which has its first common occurrence in the latest Oligocene or early Miocene. The presence of $C$. vigilans in the absence of Rocella gemma, therefore, indicates that the present assemblage conforms to the portion of the upper Oligocene $N$. biapiculata Zone stratigraphically below the initial appearance of Rocella gemma.

Sample 5-2, 60-62 cm, obtained at 167.5 meters, contains abundant Distephanus crux, common Cannopilus sphericus, and meager Mesocena apiculata, Naviculopsis biapiculata, $N$. trispinosa, $N$. regularis, and Dictyocha deflandrei. The reduced abundance of Naviculopsis species and the presence of $D$. deflandrei suggests that this zone is near the boundary of the $N$. biapiculata Zone and the $D$. deflandrei Zone. A large number of skeletal aberrations and enigmatic silicoflagellates also occur in this sample and may be the product of a severe and rapid change in environmental conditions at the onset of the late Oligocene.

\section{Site 269}

$\left(61^{\circ} 40.57^{\prime} \mathrm{S}, 14^{\circ} 04.21^{\prime} \mathrm{E}\right.$, water depth $\left.4285 \mathrm{~m}\right)$

Site 269 lies near the southeastern edge of the South Indian Abyssal Plain. Two holes were discontinuously cored at this site through a 1-km-thick, relatively uniform section. The entire section consists dominantly of silts and clays, with biogenic silica common in the upper half and absent in the lower half.

Core 1, obtained from 0 to 8 meters, is a siliceous ooze containing abundant and well-preserved silicoflagellates. The silicoflagellate assemblage of this core is completely dominated by Distephanus speculum and is correlative to the Distephanus speculum Zone A because of the high percentage of long-spined Distephanus speculum. Other less-frequent constituents of the assemblage include Distephanus boliviensis var. binoculus, Distephanus speculum var. pentagonus and Distephanus polyactis. Twelve samples were examined (Table 5).

Core 2, from 47 to 50 meters, contains a silicoflagellate assemblage of lower abundance than that of Core 1. A definite zonal assignment is not possible, but assemblages of similar composition and low abundance occur in early to mid-Gauss portions of the Distephanus speculum Zone B. If a Gauss paleomagnetic age is correct for Core 2 sediments, the lower D. speculum Zone A and the upper $D$. speculum Zone B are not represented but may be present in the uncored interval between Cores 1 and 2 ( 8.5 to $47 \mathrm{~m})$.

In Core 3, from 94 to 98 meters, silicoflagellate diversity and abundance continues to decrease. The highest sample, from Section 1 at $60-62 \mathrm{~cm}$, contains only specimens of Distephanus speculum s.l. and Distephanus boliviensis. The consistent occurrences of rare to few Dictyocha pseudofibula and rare occurrences of Dictyocha aspera and Dictyocha fibula characterize the interval between Section 1, at $60 \mathrm{~cm}$, and Section 3, at 82 $\mathrm{cm}$. The assemblage of this interval is placed, with reasonable confidence, in the upper Dictyocha pseudofibula Zone (approximately 3.90 m.y.B.P.). The lowest sample examined in Section 3, at $130 \mathrm{~cm}$, contains only one $D$. pseudofibula, three Mesocena diodon, and one reworked Mesocena apiculata. This lowermost assemblage may be correlative to the upper Mesocena diodon Zone.

Cores 5 and 6,190 to 202.5 meters, contain very rare silicoflagellates which are not by themselves age diagnostic.

Cores 7 to 11 , obtained from 232 to 397 meters, and all cores from Hole 269A (Cores 1-13), from 416 to 958 meters, lack silicoflagellates.

\section{Ross Sea Sites}

Ross Sea sediments generally contain low-abundance and low-diversity assemblages of silicoflagellates. Abundances and diversities are greatest in the upper few meters of sediment and in the early to mid-Pliocene sediments at Site 271. All silicoflagellates found in Ross Sea Miocene to Holocene sediments exhibit a high degree of intraspecific skeletal variability. This skeletal variability is usually manifested in the form of excessive ornamentation or incomplete skeletal formation. The skeletal variability makes taxonomic placement difficult, therefore, specific assignments must be considered as sensu lato.

\section{Site 271}

\section{$\left(76^{\circ} 43.27^{\prime} \mathrm{S}, 175^{\circ} 02.86^{\prime} \mathrm{W}\right.$, water depth $\left.562 \mathrm{~m}\right)$}

Site 271 is one of two sites in the southeastern portion of the Ross Sea. A 265-meter (24 core) sequence of sediment with apparent lithological uniformity was drilled, with only 15.3 meters of core recovery. The entire sediment sequence consists of soft to semilithified, silty clays or clayey silts with granules and larger clasts.

Silicoflagellates are rare from 21 to 30.5 meters (Core 1), absent at 40 to 175 meters (Core $2 \mathrm{~A}$ to Core 15), few to absent with varying degrees of preservation from 175 to 251 meters (Core 16 to Core 23), and common, diverse, and well preserved from 255 to 265 meters (Core 24).

Rare specimens of Distephanus speculum with wide apical rings were found in Sample 1-1, 10-12 cm. This particular morphotype of Distephanus speculum is often found in Matuyama sediments; however, no age designation is made due to the lack of other diagnostic Matuyama silicoflagellates. Sample 1, CC contains a few specimens of Naviculopsis biapiculata which may have been winnowed from an Eocene or Oligocene source elsewhere in the Ross Sea. 
The remainder of the site samples examined were barren with the exception of Cores 16, 19, and 24. Core 16 and 19 core-catcher samples yielded only several morphotypes of Distephanus speculum of an indeterminable age. Silicoflagellates were surprisingly common and diverse in Sample 24, CC. This core catcher contains Dictyocha pseudofibula, Distephanus boliviensis var. binoculus, Distephanus boliviensis, D. speculum s.l., and D. speculum var. pentagonus. This assemblage is somewhat similar to that of the Distephanus boliviensis Zone or upper Dictyocha pseudofibula Zone, thereby indicating a sediment age of approximately 3.0 to 3.7 m.y.

\section{Site 272}

$\left(77^{\circ} 07.62^{\prime} \mathrm{S}, 176^{\circ} 45.61^{\prime} \mathrm{W}\right.$, water depth $\left.629 \mathrm{~m}\right)$

Site 272 is located in the southeastern portion of the Ross Sea. The sedimentary sequence is comprised of two general units: a thin, diatomaceous silty clay $(0-23.5 \mathrm{~m})$ and a thick sequence of diatomaceous silty claystone (23.5-434 m).

Sediments at this site are either barren or contain very low abundances of silicoflagellates. Most of the specimens examined are well preserved and exhibit the same high degree of intraspecific skeletal variability characteristic of most silicoflagellates found in the sediments of the Ross Sea.

Sample 1-1, 80-132 cm, contains Distephanus speculum var. pentagonus and highly ornamented specimens of Distephanus speculum with a wide apical apparatus. Although the present morphotype of $D$. speculum is common in Matuyama sediments, no age designation is possible due to the lack of assemblage diversity.

Distephanus speculum s.l. is also present in sediments from Samples 14, CC, 18, CC, and 25, CC.

Sieved Core 35 core-catcher samples yielded common to abundant amounts of silicoflagellates of limited diversity. The assemblage at this interval is dominated by Distephanus speculum s.l., but contains one specimen of Mesocena cf. pappi which may indicate an early Miocene age because of its correlative occurrence in the lower Miocene at Site 266.

\section{Sites 273 and $273 \mathrm{~A}$}

$\left(74^{\circ} 32.29^{\prime} \mathrm{S}, 174^{\circ} 37.57^{\prime} \mathrm{E}\right.$, water depth $\left.495 \mathrm{~m}\right)$

Site 273 is located in the west-central portion of the Ross Sea on the flank of an apparent erosional valley which borders the western edge of Pennell Bank. At Site $273,346.5$ meters ( 29 cores) of sediments were cored in two holes, with a recovery of only 83.4 meters. The sedimentary sequence in the upper $\mathbf{4 2 . 5}$ meters (Cores 15 ) is comprised of a soft to stiff, diatomaceous silty clay, and the sequence from 42.5 to 346.5 meters (Cores 6-29) is a semilithified, pebbly, silty clay.

Sediments at this site generally contain lowabundance and low-diversity assemblages of silicoflagellates. The silicoflagellates from this site are well preserved and usually highly ornamented.

Core 1 contains many skeletal morphotypes of Distephanus speculum which have varying apical ring widths and spine lengths. No age assignment for the sediment of Core 1 is possible.
Samples 2, CC, 3, CC, and 6, CC, between 14 and 52 meters, are barren of silicoflagellates. Sample 5, CC, at 42 meters, contains rare specimens of Distephanus speculum s.l. Silicoflagellates are fairly common in Sample $6 \mathrm{~A}-1,120-122 \mathrm{~cm}$. This core contains the following silicoflagellate assemblage which is suggestive of a Miocene age: Distephanus speculum var. pentagonus, $D$. cf. crux, D. cf. boliviensis, $D$. speculum, and $D$. cf. longispinus. This assemblage also contains a variety of specific morphotypes and a number of aberrant forms with incomplete skeletons.

Cores $8 \mathrm{~A}$ through $28 \mathrm{~A}$, obtained between 166 and 337 meters, contain low abundances of Distephanus speculum s.l. No age assignment is possible for this interval of sediment.

\section{Site 274}

$\left(68^{\circ} 59.81^{\prime} \mathrm{S}, 173^{\circ} 25.64^{\prime} \mathrm{E}\right.$, water depth $\left.3326 \mathrm{~m}\right)$

Site 274 lies on the Antarctic lower continental rise about $250 \mathrm{~km}$ north northeast of Cape Adare. This site was originally designated as a contingency site but was occupied when severe ice and weather conditions prevented occupation of the originally designated site. Objectives at this site were to sample and date the basement horizon which was thought to be as old as Eocene (as inferred from the regional studies of Weissel and Hayes [1973]) to investigate the nature and cause of the thin sediment cover, to study the effects of glaciation at a site distal to the Ross ice shelf, and to retrieve a continuously cored section for biostratigraphic study.

At Site 274, a largely terrigenous, clay-rich sedimentary sequence of about 415 meters was recovered above basalt basement. The 34 cores of the upper 328 meter Pleistocene-Oligocene sequence generally contain abundant diatoms and/or silicoflagellates. From 328 meters to basement, a semilithified to lithified silty claystone with interbedded chert was encountered with only a trace of diatoms and no silicoflagellates present.

Cores 1 through 4 , obtained between 0 and 30.5 meters below the sea floor, contain generally scarce quantities of poorly preserved silicoflagellates. The assemblage of this interval conforms to the Pleistocene Distephanus speculum A Zone, which according to its occurrence in paleomagnetically dated Eltanin cores, spans the last 700,000 years.

The highest sample studied $(1-2,60 \mathrm{~cm}) 2$ meters below the sea floor, contains lower Oligocene or Eocene reworked Dictyocha hexacantha, Distephanus crux, Mesocena apiculata, and Corbisema triacantha. Underlying the highest sample, at 2 meters, younger Pliocene reworked Distephamus boliviensis, D. sp. cf. boliviensis, and Dictyocha pseudofibula are found throughout the remaining 24 samples of the $D$. speculum Zone A. The location of Site 274 on the continental rise distal to the Ross Sea suggests that the source of reworking was the nearby Ross Sea. The presence of Eocene or lower Oligocene specimens indicates that reworked silicoflagellates have either been transported to Site 274 from different source areas of different ages, or they have come from a single source area that has undergone erosion of continuously older sediments, thereby depositing older sediments upon younger. 


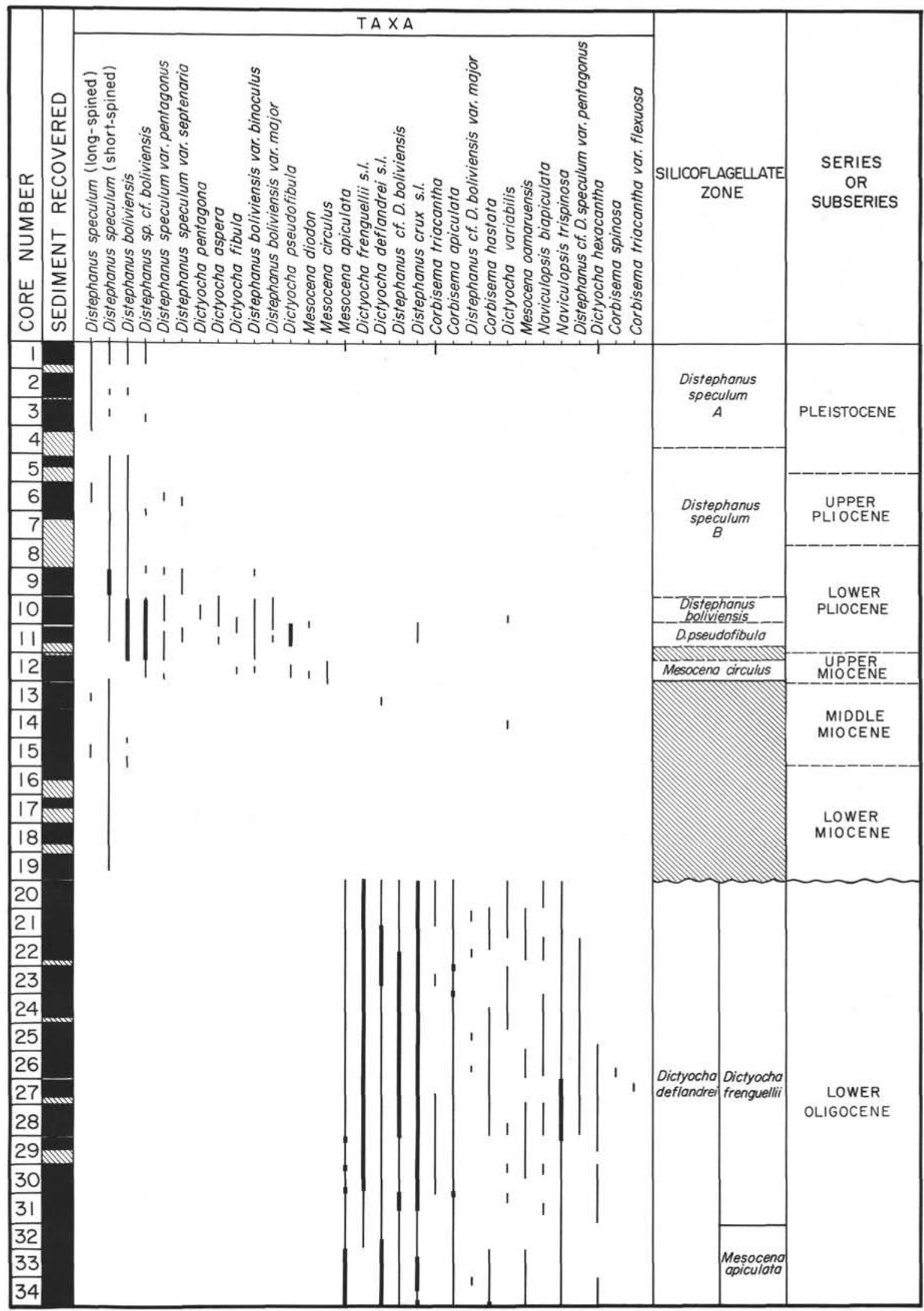

Figure 4. Ranges of selected silicoflagellates at Site 274 with zones and geologic series and subseries. 


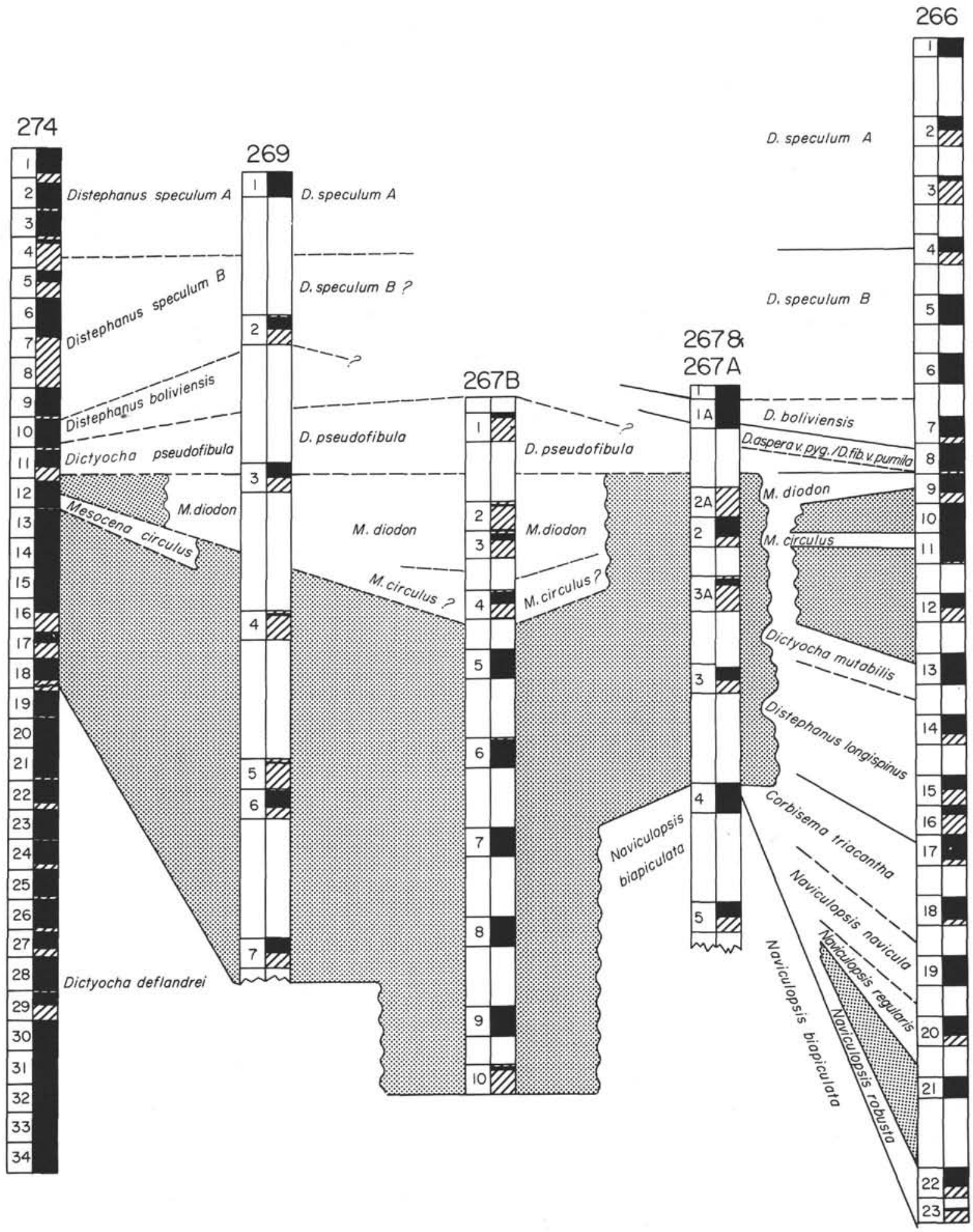

Figure 5. Correlation of silicoflagellate zones in Leg 28 Sites. Shaded areas represent intervals with insufficient floral diversity or abundance for zonal determinations.

Twenty-nine samples examined in Cores 5,6 , and 7 , at 39 to 59.5 meters, are referable to the Distephanus speculum B Zone. The assemblage is characterized by a higher proportion of short-spined than long-spined $D$. speculum, and the rare, but consistent, occurrence of $D$. boliviensis. One reworked Distephanus crux occurs in Section 2 of Core 5 , at $40 \mathrm{~cm}$. Core 8 , from 66.5 to 76 meters, was retrieved empty.

Core 9, at 76.5 to 85 meters, is also assignable to the Distephanus speculum B Zone. A few specimens of 
reworked Distephanus crux and Naviculopsis regularis were recorded in Sections 1 and 2, respectively.

Core 10, from 86.5 to 93.5 meters, contains commonly well-preserved silicoflagellates. Distephanus boliviensis occurs commonly between Section 1 at $90 \mathrm{~cm}$ and Section 6 at $42 \mathrm{~cm}$, thus suggesting that this interval conforms to the Distephanus boliviensis Zone. Other taxa found in this core include Dictyocha fibula, Dictyocha aspera, Dictyocha pseudofibula, Distephanus boliviensis var. major, D. boliviensis var. binoculus, and Distephanus speculum var. pentagonus.

The two lowermost samples (Sample 10-6, 90-142 cm) differ from the remainder of the Core 10 assemblage by the additional common occurrence of Dictyocha pseudofibula. The uppermost range of $D$. pseudofibula in these samples represents the upper portion of the $D$. pseudofibula Zone which has its upper boundary with the $D$. boliviensis Zone between 42 and $90 \mathrm{~cm}$ in Section 6. At more northerly latitudes, the Distephanus boliviensis Zone lies conformably above the Dictyocha aspera var. pumila-Dictyocha fibula var. pygmaea Zone and not above the Dictyocha pseudofibula Zone. An ecologic restriction of the $D$. aspera var. pumila- $D$. fibula var. pygmaea Zone to latitudes north of Site $274\left(69^{\circ} \mathrm{S}\right)$ results in this conformable position of the $D$. pseudofibula Zones at this site.

Ten samples from Core 11 , at 96.5 to 101 meters, yielded common to abundant Dictyocha pseudofibula and are thus placed in the Dictyocha pseudofibula Zone of the early Pliocene. A significant number of warmwater species in this core, such as Dictyocha pseudofibula, Dictyocha aspera, and D. fibula, suggest warmer climatic conditions in the early Pliocene than today (see paleoenvironmental interpretations).

Core 12 , from 105.5 to 113.5 meters, contains a relatively meager but moderately well-preserved silicoflagellate assemblage. The upper seven samples from Section 1 through Section 3, at $90 \mathrm{~cm}$, contain no agediagnostic species. The remaining Core 12 samples examined, from Section 3 at $140 \mathrm{~cm}$ to the basal $10 \mathrm{~cm}$ of the core, conform to the Mesocena circulus Zone.

Cores 13 through 19 , from 114 to 179 meters, contain a floral assemblage of extremely low diversity and abundance. Preservation is poor, and a large percentage of the specimens found were broken. The only species found with any regularity in this interval are Distephanus speculum and D. boliviensis. An insufficient occurrence of age-diagnostic silicoflagellates prevents a zonal assignment for these cores.

Cores 20 to 34 , obtained from 181 to 321.5 meters, contain an unusually uniform assemblage of silicoflagellates of excellent preservation and high abundance. Species ranging throughout the 140 -meter sequence include Mesocena apiculata, Dictyocha deflandrei s.l., Distephanus cf. D. boliviensis, Distephanus crux, Corbisema apiculata, and Naviculopsis trispinosa (Table 6). The entire section between Cores 20 and 34 is herein defined as the Dictyocha deflandrei Zone. This zone is subdivided into two subzones on the basis of the evolutionary appearance of Dictyocha frenguellii. The lower part of the section from the base of Core 34 to the base of Core 30 ( 321.5 to $283.5 \mathrm{~m}$ ), which contains common Mesocena apiculata and lacks Dictyocha frenguellii, is designated as the Mesocena apiculata Subzone. The upper portion of the Dictyocha deflandrei Zone from Core 30 , at 283.5 meters, to Core 20 , at 181 meters, that is characterized by the common occurrence of Dictyocha frenguellii, is designated as the Dictyocha frenguellii Subzone.

\section{PALEOENVIRONMENTAL INTERPRETATIONS}

\section{Introduction}

The potential of silicoflagellates as paleoecologic indicators was first demonstrated early this century with the observation of their biogeographic provinciality (Gemeinhardt, 1931, 1934; Lohmann, 1919). This biogeographic provinciality of living silicoflagellate populations has been shown to be largely a result of temperature control on taxonomic development. The influence of temperature on taxonomic composition is best reflected in a reversal in dominance between the genera Dictyocha and Distephanus in warm and cold water, respectively (Gemeinhardt, 1934). Various schemes have been proposed for using the silicoflagellate genera Dictyocha and/or Distephanus in paleotemperature determinations. A scheme proposed for determining relative paleotemperatures measures the percentage of Dictyocha in the silicoflagellate assemblage (Jendrzejewski and Zarillo, 1971). Two schemes proposed for determining absolute paleotemperatures relate surface water temperatures to the ratio of Dictyocha fibula to Distephanus speculum (Martini, 1971), and the ratio of Dictyocha to Distephanus species (Mandra, 1958).

In the present study, both the Mandra and Martini techniques for absolute paleotemperature determination were tested on two paleomagnetically dated Eltanin cores, E 50-28 and E 38-8, in order to determine their accuracy for use in the Southern Ocean. Application of the Martini method resulted in entirely unreasonable temperature range fluctuations of $0^{\circ}-25^{\circ} \mathrm{C}$ throughout sediment intervals representative of only several thousand years. Climatic fluctuations delineated from these cores by the Mandra paleotemperature method (Ciesielski and Weaver, 1973; Weaver and Ciesielski, 1973) were considered accurate; however, anomalously high paleotemperatures (in excess of $20^{\circ} \mathrm{C}$ ) were obtained.

\section{Techniques}

Silicoflagellate Paleotemperature Technique

Because of the inaccuracy of the preexisting silicoflagellate paleotemperature techniques, an evaluation of the relationship between Southern Ocean surface water temperatures and Dictyocha and Distephanus abundances was undertaken. The technique devised to determine Southern Ocean temperature relationships to Dictyocha/Distephanus ratios is essentially to determine the ratio of these genera in recent sediments and correlate this ratio to the mean annual surface temperatures of the overlying water mass. The area selected to test the 
usefulness of this technique in high latitudes against the previously established method developed at low and middle latitudes is between Australia and Wilkes Land, Antarctica, from $30^{\circ}$ to $63^{\circ} \mathrm{S}$ latitude, and in close proximity to the lower Pliocene cores previously studied.

Fifty phleger and trigger core surface sediment samples from similar depths and at close latitudinal intervals $\left(1^{\circ}-2^{\circ}\right)$ were studied. Dictyocha/Distephanus ratios within the surface sediment were plotted against the overlying mean annual surface water isotherms (from Gordon and Goldberg, 1970) and a best-fit curve was constructed from the plotted points (Ciesielski, 1974).

Paleotemperature assignments utilizing this technique are compared in Table 7 with the temperature assignments derived from Mandra's (1958) paleotemperature curve. Examination of the Dictyocha/Distephanus ratios of surface sediments from the Southern Ocean reveals that major changes in these ratios occur in sediments immediately across major oceanographic boundaries thereby verifying their generic sensitivity to temperature change (the temperature change across the Antarctic Convergence Zone is approximately $3^{\circ}-4^{\circ} \mathrm{C}$ ). Dictyocha/Distephanus ratios $\geqq 1$ are consistently found in the surface sediments north of the Antarctic Convergence, where mean annual surface water isotherms are $\geqq 7^{\circ} \mathrm{C}$; however, ratios $<0.50$ are generally present in surface sediments south of the Antarctic Convergence, where mean annual surface water isotherms are $\leqq 4^{\circ} \mathrm{C}$.

The maximum and minimum temperatures of the paleotemperature curve are determined at latitudes where Dictyocha and Distephanus become absent or nearly absent for the first time. South of $55^{\circ}$ to $56^{\circ} \mathrm{S}$ latitude Dictyocha is generally absent from surface sediments and north of $39^{\circ}$ to $40^{\circ} \mathrm{S}$ latitude Distephanus occurs in diminutive quantities. Mean annual surface water isotherms are $\sim 1^{\circ} \mathrm{C}$ at $57^{\circ} \mathrm{S}$ latitude and $\sim 13^{\circ} \mathrm{C}$ at $39^{\circ} \mathrm{S}$ latitude; therefore, the constructed paleotemperature curve has a temperature resolvability range from $1^{\circ}$ to $13^{\circ} \mathrm{C}$.

The constructed paleotemperature technique is dependent upon the behavior of living silicoflagellate species in the assemblage; therefore, use of this technique on assemblages other than Recent is based on the assumption that the ecological response of the organisms has been similar during past geologic epochs. It is also true that the older the geologic age of the sediment, the smaller the percentage of living species in an assemblage. It is therefore desirable to limit the use of the developed paleotemperature technique to only Pleistocene and Pliocene sequences because older sequences contain a high percentage of taxa which are now extinct or without living counterparts.

\section{Relative Silicoflagellate Paleotemperature (Td) Values}

Absolute paleotemperature determinations of Leg 28 Miocene and Oligocene sequences utilizing the previously described technique are not possible because most taxa are no longer living and therefore have undetermined temperature tolerances. However, the general
TABLE 7

Comparison of Surface Water

Temperature Estimates Based on

Dictyocha/Distephanus Ratios

\begin{tabular}{lcl}
\hline \multicolumn{1}{c}{ Ratio } & $\begin{array}{c}\text { Mandra and } \\
\text { Mandra (1972) }\end{array}$ & Revised \\
\hline 0 & $4^{\circ} \mathrm{C}$ & $1-1.5^{\circ} \mathrm{C}$ \\
$0.10-0.50$ & $4-15^{\circ} \mathrm{C}$ & $2.5-5^{\circ} \mathrm{C}$ \\
$0.50-1.0$ & $15-21^{\circ} \mathrm{C}$ & $5-7^{\circ} \mathrm{C}$ \\
$1.0-3.5$ & $21-25^{\circ} \mathrm{C}$ & $7-10^{\circ} \mathrm{C}$ \\
$>3.5$ & $25^{\circ} \mathrm{C}$ & $10^{\circ}+\mathrm{C}$ \\
\hline
\end{tabular}

warm- or cold-water tolerances of Miocene and Oligocene genera are understood on the basis of the biogeographic distribution of extinct taxa and the paleoecological requirements of their living representatives.

A method, patterned after Kanaya and Koizumi (1966), is utilized for determining relative paleotemperature (Ts) values for the Miocene and Oligocene at Sites 266 and 274. The determined Td values =

$$
\frac{X_{W}}{X_{W} \cdot X_{C}} \cdot 100
$$

where $X_{w}=$ total specimens of warm-water genera and $X_{c}=$ total specimens of cold-water genera. The resultant number can vary from 0 (when $X_{w}=0$ ) to 100 (when $X_{c}=0$ ). This silicoflagellate Ts value is only a relative measure between cold (0) and warm (100) temperatures. In the present scheme Distephanus and Cannopilus are considered cold-water genera whereas Naviculopsis, Dictyocha, and its ancestral genus Corbisema are considered as warm-water genera. Mesocena is considered to have intermediate temperature tolerances and is tabulated with $X_{W}$ and $X_{c}$ to prevent bias.

Early Pliocene Temperature Changes (Sites 266, 274, and E 50-28, E 38-8, E 36-33, E 14-8)

\section{Sediment Sampling and Quantitative Floral Analysis}

Eltanin piston cores were initially sampled at $20-\mathrm{cm}$ intervals, but additional samples were taken at $10-\mathrm{cm}$ intervals over those core sections where significant changes in Dictyocha/Distephanus ratios were noted. Glomar Challenger drill cores were generally sampled at 50-cm intervals. Dictyocha and Distephanus species counts of not less than 100 specimens per slide were made on all surface sediments and core samples.

\section{Results}

Calculations of silicoflagellates ratios from six piston and drill cores (Figure 6, Table 8) indicate that a minimum of seven time-correlative changes occurred in the regional oceanographic regime of the Southern Ocean during the early Pliocene (Figure 7, Table 9). Temperatures fluctuated between those now found north of the present position of the Antarctic Convergence (Gilbert climatic events II, IV, V, VII) to those restricted south of this oceanographic boundary (Gilbert I, III, and VI). 


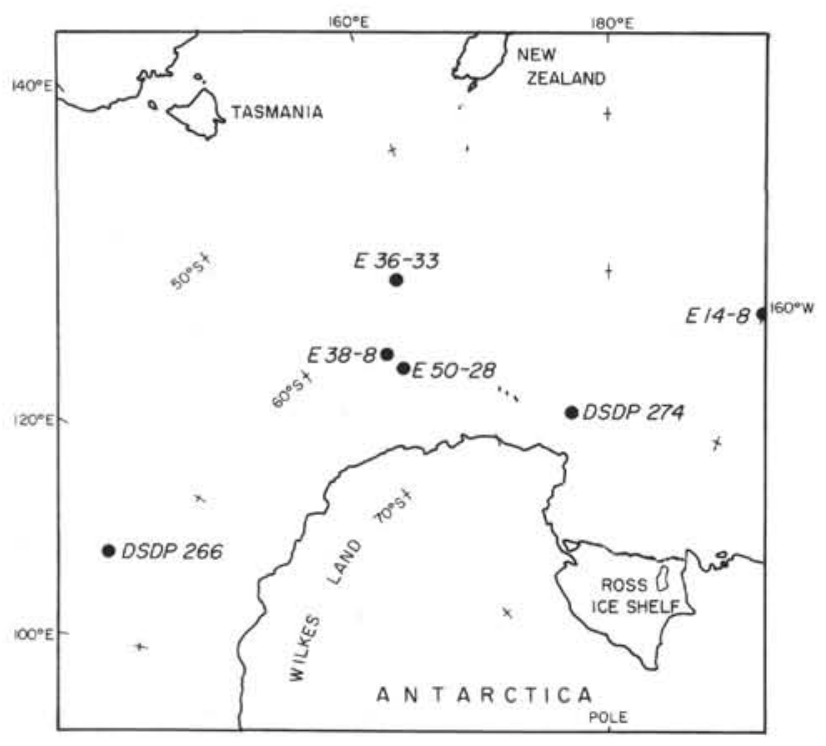

Figure 6. Location map of Eltanin piston cores and Deep Sea Drilling Project drill cores utilized in silicoflagellate paleotemperature determinations. (See Table 8 for coordinates and depths.)

The highest paleotemperatures are recorded in lower Gilbert age sediments (Gilbert V, $T=4.00 \mathrm{~m} . \mathrm{y} . \mathrm{B} . P$. and Gilbert VII, $T=\sim 4.25$ ), where Dictyocha/Distephanus ratios are $\geqq 1.0$ at all sample intervals within these events. Temperatures as high as $10^{\circ} \mathrm{C}$ appear to have been prevalent in waters as far south as $63^{\circ}$ and possibly $69^{\circ} \mathrm{S}$ latitude (Figure 7), indicating Northern Subantarctic conditions during these events. Temperatures at
TABLE 8

Location and Depths of Samples From Which Silicoflagellate Temperatures Are Determined

\begin{tabular}{lllc}
\hline \multicolumn{1}{c}{ Sample } & Latitude & Longitude & $\begin{array}{c}\text { Depth } \\
\text { (Fathoms) }\end{array}$ \\
\hline DSDP 274 & $68^{\circ} 59^{\prime} \mathrm{S}$ & $173^{\circ} 25^{\prime} \mathrm{E}$ & 1663 \\
E 50-28 & $62^{\circ} 54^{\prime} \mathrm{S}$ & $150^{\circ} 41^{\prime} \mathrm{E}$ & 1908 \\
E 38-8 & $61^{\circ} 48^{\prime} \mathrm{S}$ & $149^{\circ} 54^{\prime} \mathrm{E}$ & 1800 \\
E 14-8 & $59^{\circ} 40^{\prime} \mathrm{S}$ & $160^{\circ} 17^{\prime} \mathrm{W}$ & 1830 \\
E 36-33 & $57^{\circ} 46^{\prime} \mathrm{S}$ & $154^{\circ} 55^{\prime} \mathrm{E}$ & 1877 \\
DSDP 266 & $56^{\circ} 24^{\prime} \mathrm{S}$ & $110^{\circ} 06^{\prime} \mathrm{E}$ & 2087 \\
\hline
\end{tabular}

this time would have been $8^{\circ}-10^{\circ} \mathrm{C}$ higher than those found at similar latitudes today, suggesting that Northern Subantarctic waters were displaced significantly south of their modern position during the lower Gilbert magnetic epoch.

Antarctic temperatures, similar to and possibly lower than those of the Holocene, are indicated for Gilbert events I $(T=3.55-3.70)$ and III $(T=3.80-3.85)$. At all sample intervals within these events the Dictyocha/Distephanus ratios are 0.07 , and in most sample intervals within Gilbert I (Figure 7) essentially no specimens of Dictyocha were counted. Dictyocha is only absent in modern Antarctic sediments south of $\sim 56^{\circ} \mathrm{S}$ latitude where surface water temperatures remain throughout the year between $<0^{\circ}$ and $1.5^{\circ} \mathrm{C}$. Gilbert III event spans only a short time interval, whereas Gilbert I, apparently the most severe Gilbert cooling, lasted throughout the entire upper Gilbert above event "a" with some indication of a warming prior to the GilbertGauss boundary. It is important to note that these cool-

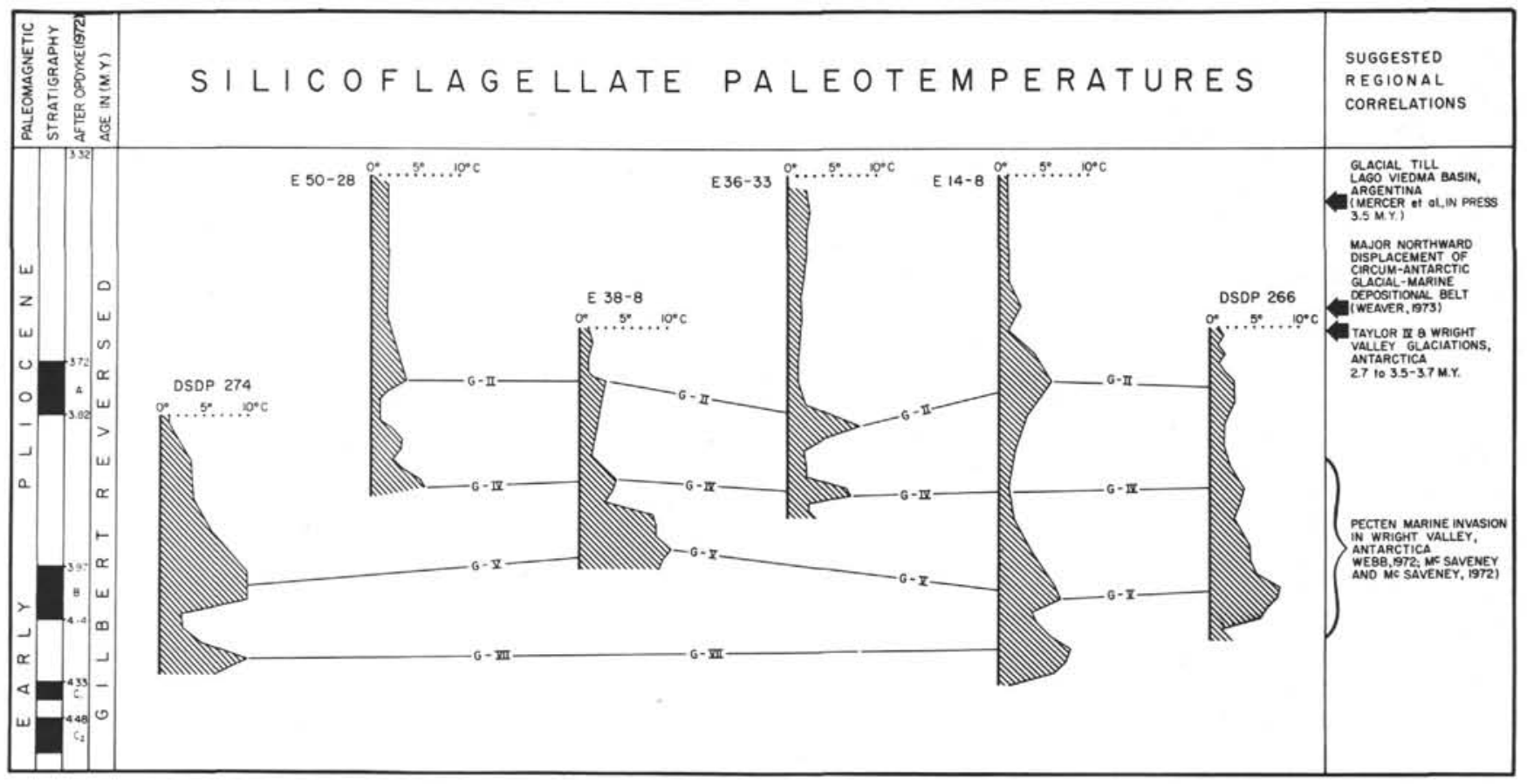

Figure 7. Early Pliocene paleotemperatures and climatic events and regional correlation of continental glacial and interglacial evidence. Core correlations based on close interval diatom, radiolarian, and silicoflagellate biostratigraphy, and Eltanin core paleomagnetic stratigraphy. 
TABLE 9

Paleomagnetic Age Determinations of Early Pliocene Climatic Events Recorded Between $69^{\circ}-57^{\circ} \mathrm{S}$ Latitude

\begin{tabular}{lccl}
\hline Event & $\begin{array}{c}\text { Approximate Paleomagnetic } \\
\text { Age (m.y. B.P.) }\end{array}$ & $\begin{array}{c}\text { Calculated Temperature } \\
\text { Range (Seasonal Average) }\end{array}$ & Climatic Regime \\
\hline Holocene & - & $<0-1-2^{\circ} \mathrm{C}$ & Antarctic \\
Gilbert I & $3.35-3.70$ & $<1.5-2^{\circ} \mathrm{C}$ & Antarctic \\
Gilbert II & $\sim 3.75$ & $3-7^{\circ} \mathrm{C}$ & Subantarctic \\
Gilbert III & $3.80-3.85$ & $<1.5-2^{\circ} \mathrm{C}$ & Antarctic \\
Gilbert IV & $\sim 3.90$ & $4-6^{\circ} \mathrm{C}$ & Subantarctic \\
Gilbert V & $3.95-4.05$ & $7-10^{\circ} \mathrm{C}$ & Northern Subantarctic \\
Gilbert VI & $4.15-4.25$ & $3-4^{\circ} \mathrm{C}$ & Northern Antarctic \\
Gilbert VII & $\sim 4.25-?$ & $8-10^{\circ} \mathrm{C}$ & Northern Subantarctic \\
\hline
\end{tabular}

ing events recorded in Gilbert events I and III might reflect the initial establishment of true Antarctic climatic conditions within the Southern Ocean during the Pliocene, although little paleoclimatic information is available for the interval between Gilbert event "c" and the Epoch 5 boundary. Sediments of this age are found in Eltanin cores E 13-17 and E 34-5, and both cores contain substantial warm-water radiolarians and diatoms not endemic to Antarctic waters today.

Dictyocha/Distephanus ratios recorded at Gilbert events II, IV, and VI are similar in that they reflect a temperature range indicative of Subantarctic to northernmost Antarctic conditions (temperatures $=3^{\circ}$ $7^{\circ} \mathrm{C}$ ). Projected surface water isotherms during these climatic intervals within the study area indicate that temperatures were $3^{\circ}-5^{\circ} \mathrm{C}$ higher than those in the region today. These paleotemperatures are comparable to present-day surface water temperatures between $\sim 54^{\circ}$ and $48^{\circ} \mathrm{S}$ latitude.

Silicoflagellate paleotemperatures delineate a major cooling trend between 4.30 and 3.70 m.y.B.P. (Table 9). This early Pliocene cooling trend records a major climatic deterioration in the Southern Ocean with surface water temperatures fluctuating from those commonly associated with waters north of the modern position of the Antarctic Convergence $\left(7^{\circ}-10^{\circ} \mathrm{C}\right)$ to those found associated with Antarctic waters $\left(<1.5^{\circ} \mathrm{C}\right)$.

\section{Interpretation}

Mercer (1968) suggests that the West Antarctic ice sheet is a uniquely vulnerable and unstable body of ice which cannot exist unless composed of cold ice throughout. Because it is in equilibrium with the Ronne and Ross ice shelves, any changes in horizontal forces due to a climatically induced recession of these ice shelves would cause the grounded ice sheet to lift off the sea bottom. With further warming, it would revert to a single ice shelf and eventually would thin to pack ice similar to that found off the Antarctic today. Mercer estimates that destruction of the ice sheet would start if summer temperatures rose more than $4^{\circ} \mathrm{C}$ above present levels and would be completed if temperatures rose $10^{\circ} \mathrm{C}$.

Silicoflagellate paleotemperature estimates (G-VII and G-V; $T=4.25-3.95$ m.y.B.P.) for middle and lower Gilbert cores taken as far south as $69^{\circ} \mathrm{S}$ latitude, average $8^{\circ}$ to $10^{\circ} \mathrm{C}$ higher than those found in the Southern
Ocean today. These temperatures would satisfy Mercer's (1968) requirements for partial or complete absence of the west Antarctic ice sheet during this interval of time. In addition, a marginal recession of the east Antarctic ice sheet would have occurred simultaneously, because the present $-10^{\circ} \mathrm{C}$ January isotherm lies only slightly inland along the East Antarctic coast (Tolstikov, 1966).

Continental evidence in support of early Pliocene warm conditions comes from recent research on Pecten deposits in Wright Valley, Antarctica. Webb (1972), Bull and Webb (1973), and others have studied the sedimentology and paleontology of these Pecten deposits and conclude that they were deposited in a fjord which extended a minimum of $40 \mathrm{~km}$ up Wright Valley from McMurdo Sound. Webb's (1972) study of benthic foraminifera within the Pecten deposits led him to suggest a fjord depth of approximately 100 meters and bottom water temperatures somewhere between $-2^{\circ}$ and $5^{\circ} \mathrm{C}$, and perhaps as high as $10^{\circ} \mathrm{C}$. Webb believes it is likely that warm interglacial conditions existed in Wright Valley during the time of Pecten deposition. It is the author's opinion that the Pecten "Interglacial" conditions in Wright Valley may be time-correlative with "warm conditions" recorded in Antarctic deep-sea sediments between 4.3 and 3.95 m.y.B.P. (Figure 7).

Previous marine evidence suggesting a warm early Pliocene in the Southern Ocean comes from documentation of subtropical collosphaerid radiolarians in Gilbert sediments from two cores taken in the South Pacific sector of the Southern Ocean (Bandy et al., 1971). These authors suggest a $15^{\circ} \mathrm{C}$ change in surface water temperatures during the Gilbert at event " $\mathrm{c}$ " or between events "c" and "a," defined at the level of total disappearance of the collosphaerid radiolarians. Early Pliocene paleotemperatures presented here are substantially lower, but generally corroborate their earlier climatic interpretation of a very warm early to midGilbert.

Between 3.95 and 3.70 m.y.B.P. (G-IV through G-I), a major cooling trend is recorded in the Southern Ocean region (Figure 7, Table 9). It is in general agreement with the earlier findings of Bandy et al. (1971) based on radiolarian data. Surface water temperatures delineated in this study indicate a decline from temperatures characteristic of northern Subantarctic waters to those associated with modern Antarctic waters, rather than a 
decrease from tropical or subtropical temperatures, as suggested by Bandy et al. (1971).

Pliocene temperatures characteristic of Antarctic waters were initially established by Gilbert III (Table 9) or by Gilbert I at the latest. Silicoflagellate temperature data indicate that due to the total absence of the genus Dictyocha at the beginning of Gilbert I, this cooling may have been one of the most severe recorded during the Pliocene.

Further evidence to substantiate this was found in the Southern Ocean sedimentary record; Weaver (1973) recorded this same cooling event in marine sediments adjacent to the Adelie coast of East Antarctica. He noted a major northward displacement of the glacialmarine/siliceous ooze sediment boundary following Gilbert event "a," and referred to this event as Gilbert cooling I (Figure 7). After correcting the latitudinal position of his core material for southerly movement due to sea-floor spreading since the early Pliocene, he calculated that the characteristic glacialmarine/siliceous ooze boundary in the Southern Ocean must have been displaced $1^{\circ}$ to $1-1 / 2^{\circ}$ further north than its Holocene position. This displacement indicates more severe climatic conditions in the Antarctic region than at present.

This severe late Gilbert cooling event is also substantiated by continental evidence. Mercer et al. (in press) have discovered evidence for a major glaciation in Argentine Patagonia (Figure 7) which is apparently the first to affect the area and is approximately time equivalent to Gilbert I. They have documented major till deposition intercalated between lava flows with indistinguishable radiometric ages of 3.50 m.y.B.P., and have concluded that this glaciation probably resulted from a major increase in Antarctic ice cover.

In conclusion, the data imply that temperatures in the Antarctic during the early Pliocene between 4.3 and 3.95 m.y.B.P. were much higher than they are today. Surface water temperatures calculated from Dictyocha/Distephanus ratios indicate that Antarcticwater temperatures may have been $10^{\circ} \mathrm{C}$ higher than they are today. The inferred surface water temperatures suggest the possible absence of the West Antarctic ice sheet at this time. It is further suggested that the West Antarctic ice sheet would have been established or possibly reestablished during the succeeding climatic cooling of the late Gilbert. The ice sheet could have reached its present size as early as $3.80-3.85$ m.y.B.P. (Gilbert climatic event III) but was no doubt fully developed by 3.35-3.70 m.y.B.P. (late Gilbert climatic event I).

\section{Late Miocene (Site 266)}

Fifteen samples examined from the late Miocene sequence of Site 266, between Samples 10-1, $90 \mathrm{~cm}$ and 12 $3,112 \mathrm{~cm}$, generally contain an insufficient variety and abundance of silicoflagellates for paleotemperature and Ts value determinations. Most of the stratigraphic interval is barren or nearly barren except for a bloom of Mesocena circulus between Samples 11-1, $60 \mathrm{~cm}$ and 11$3,92 \mathrm{~cm}$. The paleoecologic significance of the late Miocene occurrence of this species, at Sites 266 and 274 as well as in Falkland Plateau sediments, is relatively uncertain. The short stratigraphic range of Mesocena circulus in the Southern Ocean suggests that it may have been a stenothermal species whose thermal requirements were maintained only briefly during the changing climatic conditions of the late Miocene.

\section{Middle Miocene (Site 266)}

Silicoflagellate Ts values were calculated from 24 middle Miocene samples between 200 and 277 meters (Figures $8 \mathrm{c}, \mathrm{d}$ ). The obtained Ts values are exceptionally low or equal to zero throughout most of the middle Miocene sequence. Low Ts values and low assemblage diversities and abundances are indicative of cool middle Miocene climatic conditions. High Ts values of between 60 and 100 are recorded only in the Dictyocha mutabilus Zone, between 200 and 204 meters, and the lower Distephanus longispinus and upper Corbisema triacantha zones, between 254 and 260 meters. Several characteristics of the Corbisema triacantha Zone that are suggestive of moderate early middle Miocene conditions include: the common to abundant occurrence of the cosmopolitan species Corbisema triacantha; the presence of few to common warm-water Dictyocha aspera, $D$. fibula, and D. variabilus; and an assemblage of moderate diversity and abundance.

\section{Early Miocene (Site 266)}

Silicoflagellate Ts values were calculated from 22 samples obtained between 279 and 370 meters. The Naviculopsis navicula Zone in Core 19, between 292 and 299 meters, yields moderate Ts values varying from 30 to 60 . The Naviculopsis regularis Zone, between 311 and 315 meters, possesses slightly lower Ts values ranging from 20 to 45 . The unzoned interval of Core 21, between 330 and 337 meters, has Ts values of 0 at all sample intervals except in Section 1 where a Ts value of 50 is obtained. The Naviculopsis robusta Zone in Cores 22 and 23 , from 338 to 370 meters, contains common to abundant silicoflagellates which yield moderate to high Ts values varying from 40 to 80 .

At this site, moderate early Miocene climatic conditions are not only suggested by the obtained Ts values but also by the cosmopolitan character of the assemblage. Many of the species found in this early Miocene sequence are found, with similar abundances, in the middle latitude Mediterranean region (Sanfilippo et al., 1973). Species commonly found in the early Miocene of this site and the Mediterranean include: Corbisema triacantha, Distephanus crux, D. speculum, Naviculopsis navicula, $N$. robusta (?), and Mesocena apiculata.

\section{Early Miocene (DSDP 266):}

Ts values. Silicoflagellate Ts values were calculated from twenty-two samples obtained between 279 and 370 meters. The Naviculopsis navicula zone in Core 19, between 292 and 299 meters, yields moderate Ts values varying from 30 to 60 . The Naviculopsis regularis Zone, between 311 and 315 meters, possesses slightly lower Ts values ranging from 20 to 45 . The unzoned interval of Core 21 , between 330 and 337 meters, has Ts values of 0 


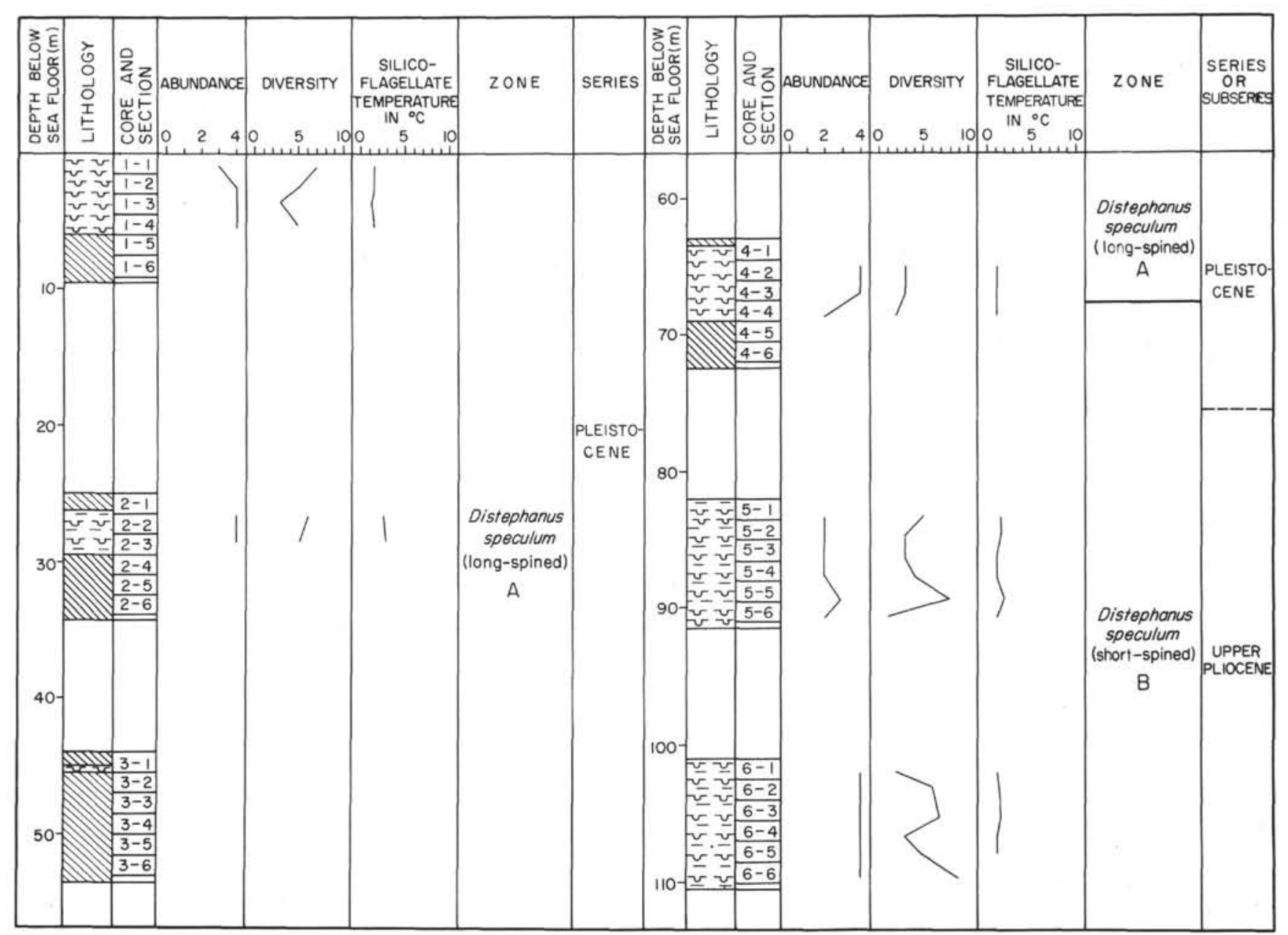

Figure 8a. Silicoflagellate abundances, diversities, and paleotemperature values for Site 266. Depths, lithologies, core and section numbers, silicoflagellate zones, and geologic series or subseries are indicated. For a discussion of the data, see text.

at all sample intervals except in section 1 where a Ts value of 50 is obtained. The Naviculopsis robusta Zone in Cores 22 and 23, from 338 to 370 meters, contains common to abundant silicoflagellates which yield moderate to high Ts values varying from 40 to 80 .

At this site, moderate early Miocene climatic conditions are not only suggested by the Ts values obtained but also by the cosmopolitan character of the assemblage. Many of the species found in this early Miocene sequence are found, with similar abundance, in the middle latitude Mediterranean region (Sanfilippo, et al., 1973). Species commonly found in the early Miocene of this site and the Mediterranean include-Corbisema triacantha, Distephanus crux, D. speculum, Naviculopsis navicula, $N$. robusta (?), and Mesocena apiculata.

\section{Late Miocene (Site 274)}

The Site 274 late Miocene sequence, between Samples $12-1,92 \mathrm{~cm}$ and $12-5,14 \mathrm{~cm}$, contains insufficient silicoflagellate occurrences for Td value determinations. Throughout the late Miocene at this site the only species occurring with any regularity is Mesocena circulus. A large number of fragmented forms occur throughout much of the section.
Associated with this sparse floral assemblage is a distinct and maintained late Miocene increase in coarse detritus (Figure 9b) and ferromanganese micronodule formation which is suggested by Frakes (this volume) to be the result of intensified ice rafting and bottom water activity caused by an expanding Ross ice shelf. The sparse and fragmented floral assemblage in the late Miocene sequence at this site is certainly not inconsistent with oceanographic and sedimentological conditions that would be associated with an expanding Ross ice shelf.

\section{Middle and Late Miocene (Site 274)}

The Site 274 early Miocene section, between Cores 16 and 19, and the middle Miocene sequence, between the base of Cores 1 and 16, contains insufficient silicoflagellate occurrences for Ts value determinations. All early Miocene stratigraphic intervals examined are either barren or contain a monospecific assemblage of Distephanus speculum. Middle Miocene sequences are similar except for the very rare occurrence of early Oligocene reworks. A large number of skeletal fragments, predominately composed of thick radial spines, are present throughout the section. A high percentage of 


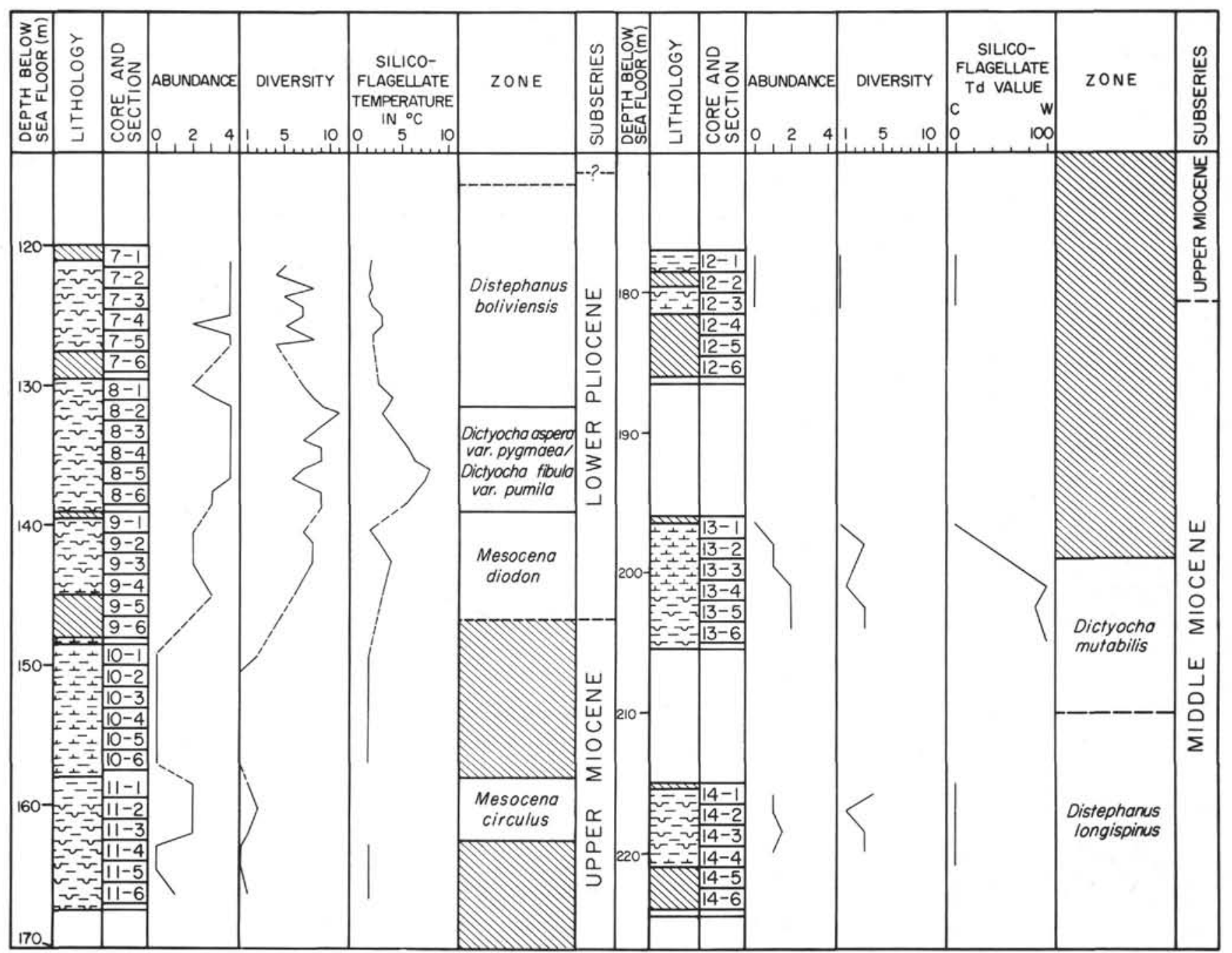

Figure 8b. Silicoflagellate abundances, diversities, paleotemperatures, and Td values for Site 266. Depths, lithologies, core and section numbers, silicoflagellate zones, and geologic subseries are indicated. For a discussion of the data, see text.

silicoflagellate fragments suggests that active cold bottom water currents, which formed the hiatus between the early Miocene (Core 19) and early Oligocene (Core 20 ), may have decreased in intensity but still were active during the early and middle Miocene.

\section{Lower Oligocene (Site 274)}

Ts values. Silicoflagellate Ts values were calculated from 82 samples taken in the lower Oligocene Dictyocha deflandrei Zone, from 181 to 321.5 meters. The obtained Td values indicate that relatively warm conditions existed throughout the interval represented. The highest Td value obtained is 80 and the lowest value 30 ; however, the majority of the values fall around 50 . Td values in the Mesocena apiculata Subzone, Cores 31 to 34 , range from 40 to 50 . A noticeable increase in Td values is seen in the lower two cores of the Dictyocha frenguellii Subzone, Cores 29 and 30 . The very high Td values, between 60 and 80 , are the result of the near dominance of the silicoflagellate population by warmwater Dictyocha species. At the base of Core 28 , Ts values decrease from 80 to 30 , in an interval of approxi- mately 5 meters. Ts values are generally between 20 and 40 throughout the slight cooling in Cores 26 and 28 . Moderate Ts values, from 30 to 50 , are maintained throughout the uppermost portion of the lower Oligocene represented in Cores 20 to 25 .

Calculations of sand abundances in the lower Oligocene section, from Core 20 to Core 34 , reveal that sand is not present in significant amounts at any interval of the section (Figures 9b-9d). The lack of significant sand deposition at this site, just distal to the Ross Sea, therefore seems to indicate that ice rafting did not commence before the deposition of Core 20 .

\section{SYSTEMATIC PALEONTOLOGY}

Most of the silicoflagellate species encountered in the present study have recently been reviewed in detail (Loeblich et al., 1968; Ling, 1970, 1972). Silicoflagellate taxonomy is given fully in these works; therefore full synonymies are not presented here. In the following, silicoflagellate genera and species are arranged in alphabetical order and relevant comments and references describing the named taxa are presented wherever deemed appropriate.

Type specimens will be deposited in the U.S. National Museum, Washington, D.C. 


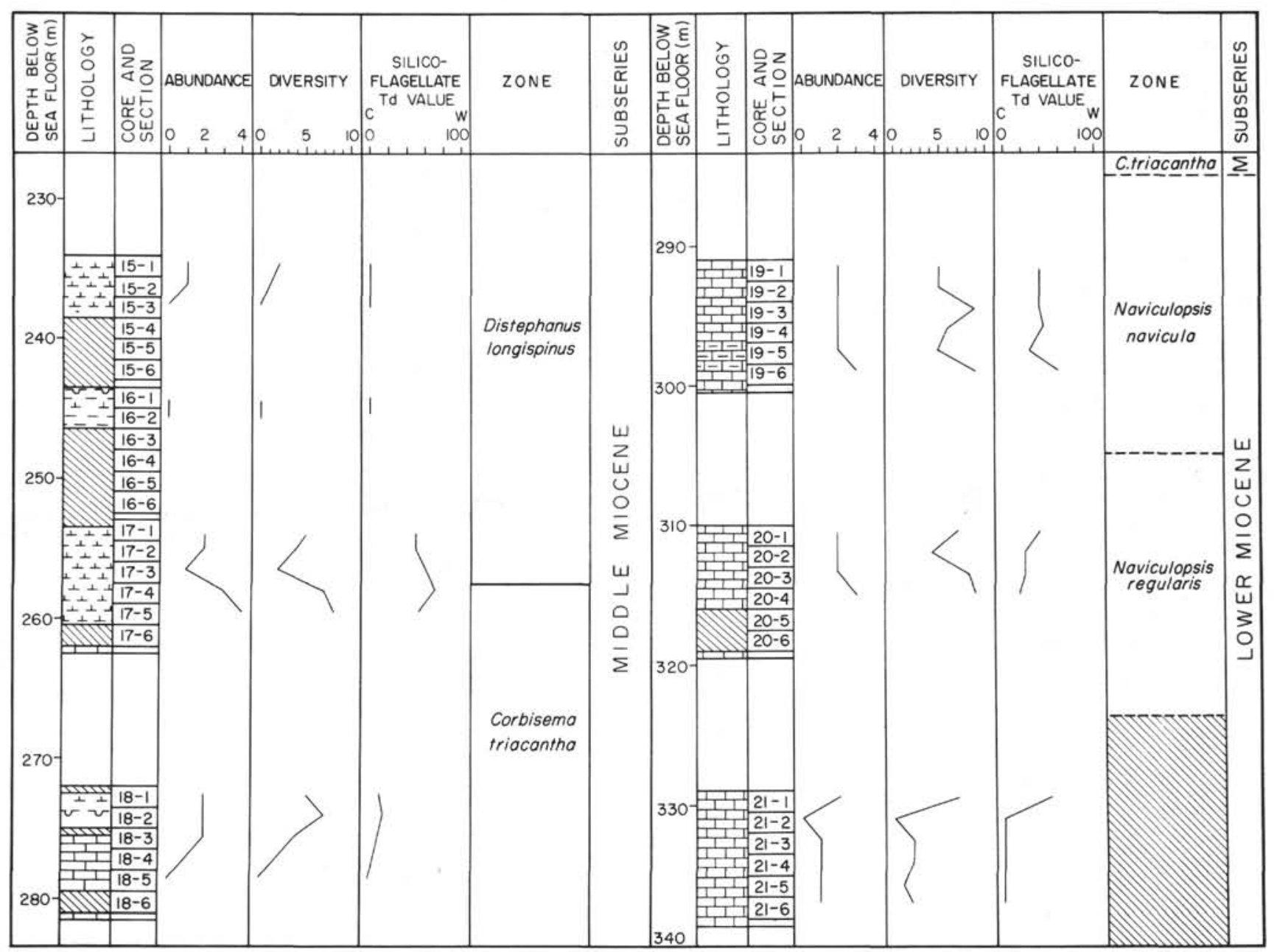

Figure 8c. Silicoflagellate abundances, diversities, and Td values for Site 266. Depths, lithologies, core and section numbers, silicoflagellate zones, and geologic subseries are indicated. For a discussion of the data, see text.

Order SIPHONOTESTALES Lemmermann, 1901

Genus CANNOPILUS Haeckel, 1887, emend. Bachmann, 1967

\section{Cannopilus antarcticus n. sp.}

(Plate 1, Figures 1-9)

Description and measurements: Basal ring, $50-58 \mu$ in diameter, and seven to nine sided with straight or convex sides, $15-25 \mu$ long. An equal number of radial spines, $4-8 \mu$, on the plane of the basal ring. No accessory spines. Apical ring relatively high standing, $30-40 \mu$ in diameter. Apical apparatus possesses 11-16 apical windows from 4 to $10 \mu$ in diameter. Total skeletal diameter between 54 and $66 \mu$.

Occurrence: Cannopilus antarcticus only occurs in one sample (17. $5,63-65 \mathrm{~cm}$ ) from the early Miocene Corbisema triacantha Zone at Site 266.

Type specimens: The holotype (Plate 1, Figures 7-9) and paratypes (Plate 1, Figures 1-6) will be deposited at the USNM. Type numbers have not been assigned but will be published in Contribution 41 of the Florida State University Sedimentological Research Laboratory.

\section{Cannopilus hemisphaericus (Ehrenberg)}

(Plate 2, Figures 2, 3)

Dictyocha hemisphaerica Ehrenberg, 1844b, p. 258, 266.

Cannopilus hemisphaericus Ling, 1972, p. 147-149, pl. 23, fig. 1-5.

Remarks: The only significant occurrence of this normally rare species is in the lower middle Miocene to lower Miocene interval of Site 266, between Cores 17 and 22. Its occurrence in this section is sporadic, and its abundance in any one sample is limited to a few specimens.

\section{Cannopilus sphaericus Gemeinhardt}

(Plate 2, Figure 1)

Cannopilus sphaericus Gemeinhardt, 1931, p. 104, pl. 10, fig. 3, 4.

Remarks: A few specimens of this species were observed in the lower middle to upper upper Miocene sections at Site 266, between Cores 18 and 20.

Genus CORBISEMA Hanna, 1928, emend. Frenguelli, 1940

\section{Corbisema apiculata (Lemmermann)}

(Plate 2, Figures 4-11)

Dictyocha triacantha var. apiculata Lemmermann, 1901, p. 259, pl. 10, fig. 19, 20.

Corbisema apiculata Ling, 1972, p. 151, 152, pl. 23, fig. 13-17.

Remarks: Those specimens found in this study which are referable to the present species have a basal ring length between 30 and $65 \mu$.

Few to common $C$. apiculata are present throughout the entire lower Oligocene section at Site 274, from Cores 20 to 34. The species has also been found in samples from Site 6 of the radiolarian Podocyrtis chalara Zone (Lutetian), in reference samples from the Bain's Farm and Totara sections of the Oamaru Diatomite, New Zealand, and in samples from the Kellogg and Sidney shales of California (Ling, 1972).

\section{Corbisema archangelskiana (Schulz)}

(Plate 3, Figures 1, 2)

Dictyocha triacantha var. archangelskiana Schulz, 1928, p. 250, 251, fig. 33a-c; p. 281, fig. 77, 78 (?). 


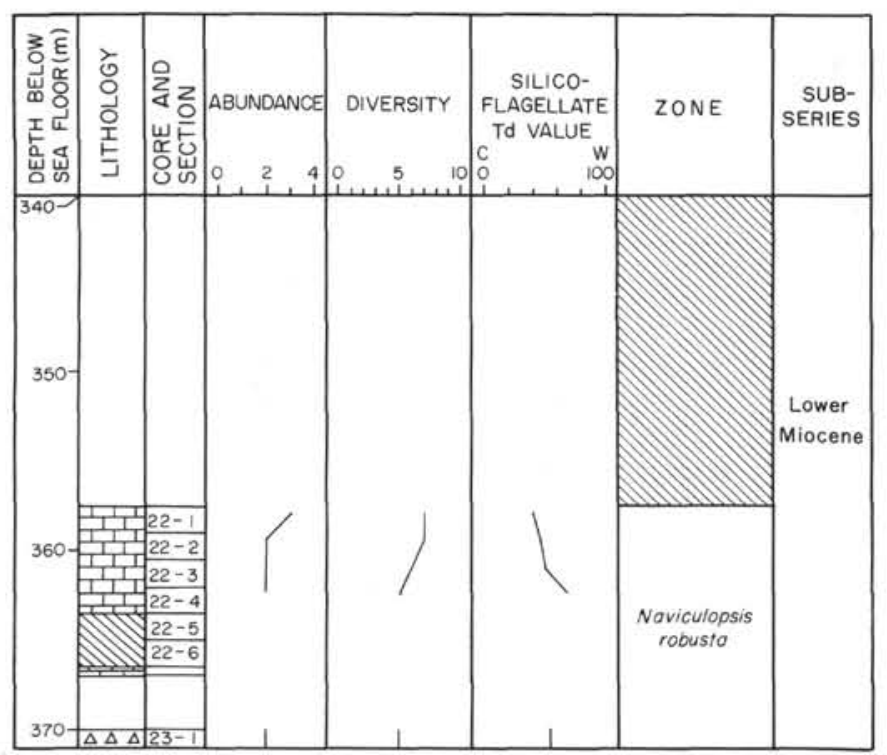

Figure 8d. Silicoflagellate abundances, diversities, and Td values for Site 266. Depths, lithologies, core and section numbers, silicoflagellate zones, and geologic subseries are indicated. For a discussion of the data, see text.

Dictyocha triacantha var. archangelskiana Gemeinhardt, 1930, p. 45, 46, fig. 37a, b (?).

Corbisema archangelskiana Frenguelli, 1940, fig. 12a; Stradner, 1961, p. 89 , fig. 25 (only); Glezer, 1966, p. 232,233 , pl. 8, fig. $6,7$.

Remarks: This distinctive species was found only in Core 4 of the Naviculopsis biapiculata Zone at Site 267, where it makes up less than $10 \%$ of the total assemblage.

\section{Corbisema hastata (Lemmermann)}

(Plate 2, Figures 12-15)

Dictyocha triacantha var. hastata Lemmermann, 1901, p. 259, pl. 10, fig. 16, 17; Schulz, 1928, p. 249, 250, fig. 31a-c, 29b (only); Gemeinhardt, 1930, p. 43, fig. 35a-c; Deflandre, 1932a, fig. 28; Frenguelli, 1940, fig. 12c (only); Glezer, 1966, p. 231, 232, pl. 6, fig. $6-8$, pl. 7, fig. 1-8, pl. 31, fig. 8, 9.

Corbisema hastata Ling, 1972, p. 155, pl. 24, fig. 5.

Remarks: Corbisema hastata occurs sporadically throughout most of the early Oligocene Dictyocha deflandrei Zone at Site 274. It has also been observed in the middle Eocene (Lutetian) Podocyrtis chalara and Thyrsocyrtis triacantha radiolarian zones at Sites 13 and 6, respectively (Ling, 1972). Late Eocene and early Oligocene occurrences have also been noted in the Soviet Union (Glezer, 1966).

\section{Corbisema spinosa Deflandre}

$$
\text { (Plate 3, Figure 9) }
$$

Corbisema spinosa Deflandre, 1950a, p. 65, fig. 178-182.

Dictyocha spinosa Glezer, 1960, fig. 31; Glezer, 1966, p. 256, pl. 10, fig. 6-8.

Remarks: Rare abundances of this species were noted in three samples of the Dictyocha frenguellii Subzone of the early Oligocene Dictyocha deflandrei Zone at Site 274.

\section{Corbisema ? sp.}

(Plate 3, Figure 7)

Remarks: This species is characterized by a triangular basal ring with three radial spines and an apical apparatus consisting of three lateral rods which merge to form a triangular-shaped apical ring. The species is tentatively placed under the present genus because of its triangular basal ring and three lateral rods; however, the presence of an apical window is not in agreement with the generic definition. The existence of an apical ring is not considered sufficient reason for exclusion of this species in the assigned genus, because all occurrences are concurrent with Corbisema triacantha, suggesting that it may be an intraspecific variation of the latter species.
Only three specimens of Corbisema ? sp. were found, one from each of the early Miocene samples, 266-19-6, 60-62 cm and 266-21-2, 62-64 $\mathrm{cm}$; and one from early Oligocene Sample $274-30-1,30-32 \mathrm{~cm}$.

\section{Corbisema triacantha (Ehrenberg)}

(Plate 3, Figures 3-6)

Dictyocha triacantha Ehrenberg, 1844a, p. 80.

Dictyocha triacantha var. triacantha fa. triacantha Glezer, 1966, p. 226, 227 , pl. 4 , fig. $1-6$, pl. 5 , fig. $1-4$.

Corbisema triacantha Ling, 1972, p. 156-157, pl. 24, fig. 8-13; Ling, 1972, p. 751, pl. 1, fig. 7, 8; Bukry and Foster, 1973, p. 826, pl. 2, fig. 3 .

\section{Corbisema triacantha var. flexuosa Stradner}

\author{
(Plate 3, Figure 8)
}

Corbisema triacantha var. flexuosa Stradner, 1961, p. 39, fig. 1-8.

Dictyocha triacantha var. flexuosa Glezer, 1966, p. 244, pl. 5, fig. 5, 6, $7,10$.

Remarks: Three specimens referable to Stradner's variety were only found in the Site 274 early Oligocene Dictyocha frenguellii Subzone of the Dictyocha deflandrei Zone at Site 274. This is the first recorded occurrence of this variety in the deep sea, as it has previously been recorded only in the late Eocene to late Oligocene of Central Europe and Asia.

All three specimens of this variety are approximately $20 \mu$ in width and have a partially hollow apical plate.

\section{Genus DICTYOCHA Ehrenberg, 1839 \\ Dictyocha aspera (Lemmermann)}

(Plate 4, Figures 2, 5)

Dictyocha fibula var. aspera Lemmermann, 1901, p. 260 , pl. 10, fig. 27 , 28.

Dictyocha aspera Bukry and Foster, 1973, p. 826, pl. 2, fig. 4, 6.

Remarks: This taxa shows a high degree of intraspecific variability in basal ring size and shape and length of the apical bar. In the present study, those specimens referred to this species have an apical bar aligned with the short axis of the skeleton.

An intraspecific variation in the orientation of the apical bar has been noted by Dumitrica (1973) in his study of double skeletons from middle Miocene samples of Romania. On the basis of variations of the apical bar in double skeletons, Dumitrica has suggested taxonomic revision of the species. Several double skeletons found in this study all had apical bars in the transverse position; therefore, at this time the taxonomic revisions suggested by Dumitrica are not followed.

Dictyocha aspera is found common to abundant in most samples of the Dictyocha pseudofibula Zone and is found less common in the Distephanus boliviensis Zone.

\section{Dictyocha aspera var. pygmaea $n . v$. \\ (Plate 4, Figures $1,3,4,6$ )}

Description and measurements: Basal ring is square or rhombic with straight or slightly convex sides, $20-36 \mu$ long. Two short radial spines, $8-12 \mu$, and two long radial spines, $20-38 \mu$, aligned normal to the highstanding apical bar. Radial spines taper and are usually curved abapically. Basal accessory spines, $2-4 \mu$, are located at the center of each basal ring side and point obliquely downward. Skeletal surface smooth.

Remarks: This variety is similar in size and ornamentation to $D$. fibuia var. pumila, but differs in possessing an apical bar oriented normal to the axis of the long radial spines.

Occurrence: $D$. aspera var. pygmaea occurs abundantly in lower Pliocene sediments between Gilbert paleomagnetic events " $a$ " and " $b$ " (3.82-3.97 m.y. B.P.). The first and last occurrences of this variety and D. fibula var. pumila define the upper and lower limits of the D. aspera var. pygmaea-D. fibula var. pumila Zone.

Type specimens: The holotype (Plate 4, Figure 4) and paratypes (Plate 4, Figures 1, 3,6) will be deposited at the USNM. Type numbers have not been received but will be published in Contribution 41 of the Florida State Sedimentological Reports.

\section{Dictyocha fibula Ehrenberg (Plate 5, Figures 1-4)}

Dictyocha fibula Ehrenberg, 1839, p. 129.

Remarks: This species is identified by the parallel alignment of the apical bar with the short axis. The taxonomic placement suggested by 


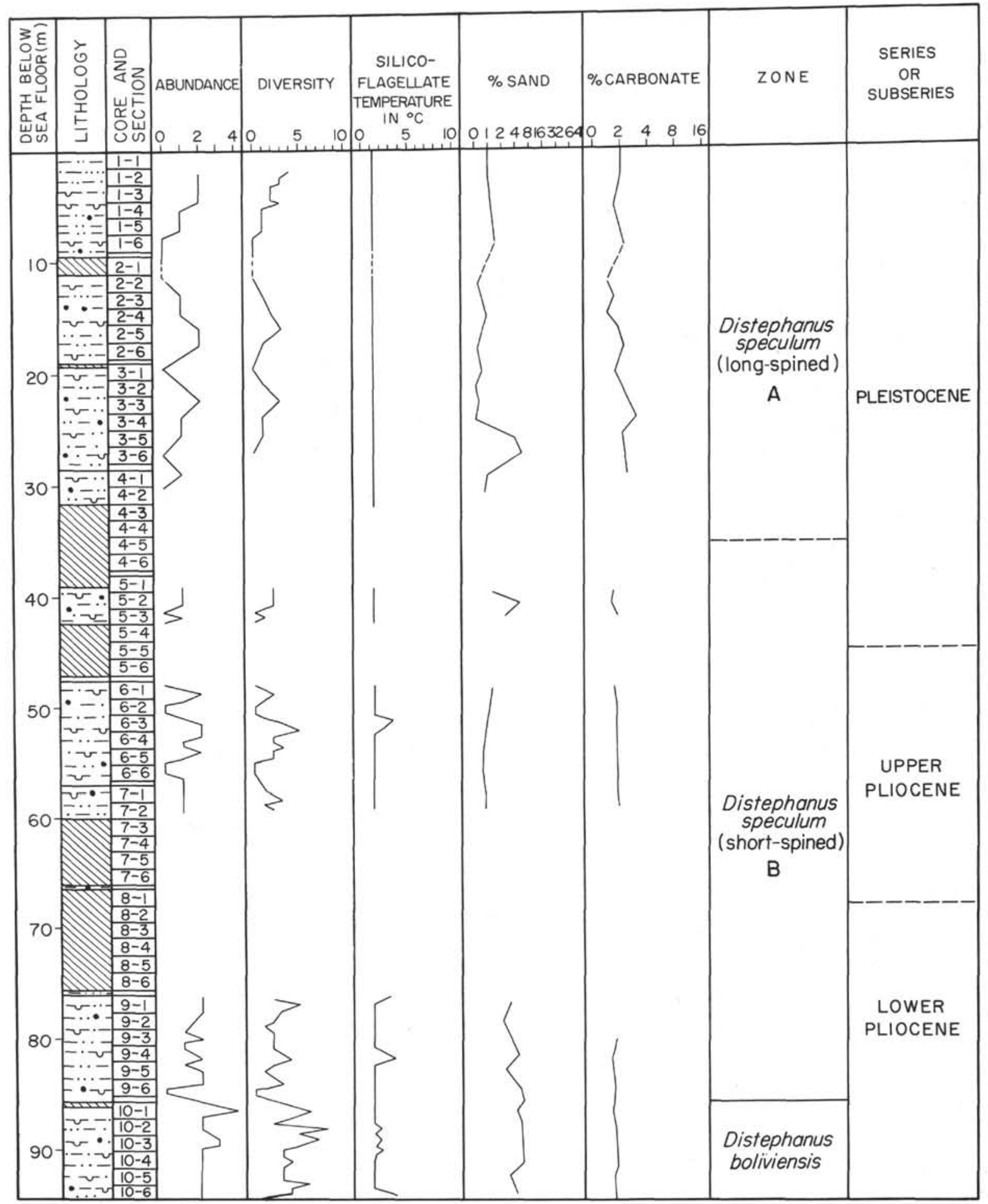

Figure 9a. Site 274 sand and carbonate percentages (Frakes, this volume) with silicoflagellate paleotemperatures, abundances, and diversities. Depths, lithologies, core and section numbers, silicoflagellate zones, and geologic series and subseries are indicated. For discussion of the data, see text.

Dumitrica (1973) is not followed at this time for similar reasons previously given in the discussion of $D$. aspera.

In the Antarctic, this species is noted to occur sporadically in the Pleistocene, Miocene, and Oligocene, but it also occurs fairly abundantly in the early Pliocene.
Dictyocha fibula var. pumila n.v.

(Plate 5, Figures 5-10; Plate 6, Figures 1, 2)

Description and measurements: Basal ring is square or rhombic with straight or convex sides, $22-35 \mu$ long. Two short radial spines, $8-18 \mu$, 


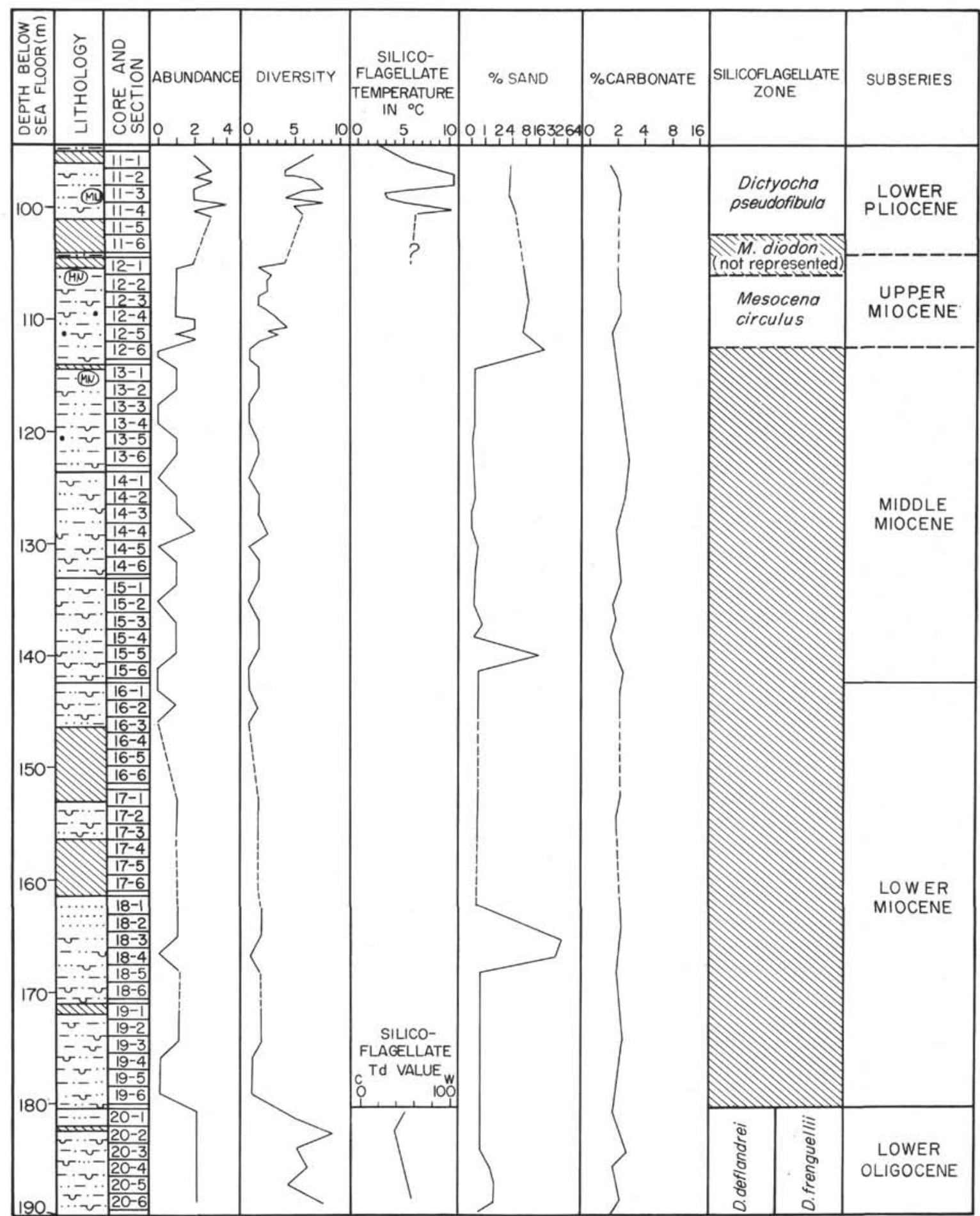

Figure 9b. Site 274 sand and carbonate percentages (Frakes, this volume) with silicoflagellate paleotemperatures, Td values, abundances, and diversities. Depths, lithologies, core and section numbers, silicoflagellate zones and subzones, and geologic subseries are indicated. For discussion of the data, see text.

and two long radial spines, $20-40 \mu$, aligned with the high-standing apical bar. Radial spines taper and are usually curved abapically. Basal accessory spines, $2-4 \mu$, located at the center of each basal ring side point obliquely downward. Skeletal surface smooth.

Remarks: Differs from $D$. fibula "var" messanensis by its overall smaller size and lack of an apical spine.

Occurrence: Dictyocha fibula var. pumila is a short-ranged variety that occurs abundantly in lower Pliocene sediments between Gilbert events "a" and "b" (3.82-3.97 m.y. B.P.). Its first to last occurrence within this interval defines the D. aspera var. pygmaea-D. fibula var. pumila Zone.

Type specimens: A holotype (Plate 5, Figure 5,6) and paratypes (Plate 5, Figures 7-10) will be deposited at the USNM. Type numbers have not yet been received but will be published in Contribution 41 of the Florida State Sedimentological Reports.

Type locality: E 50-28 (400-402), lower Antarctic Continental rise. 


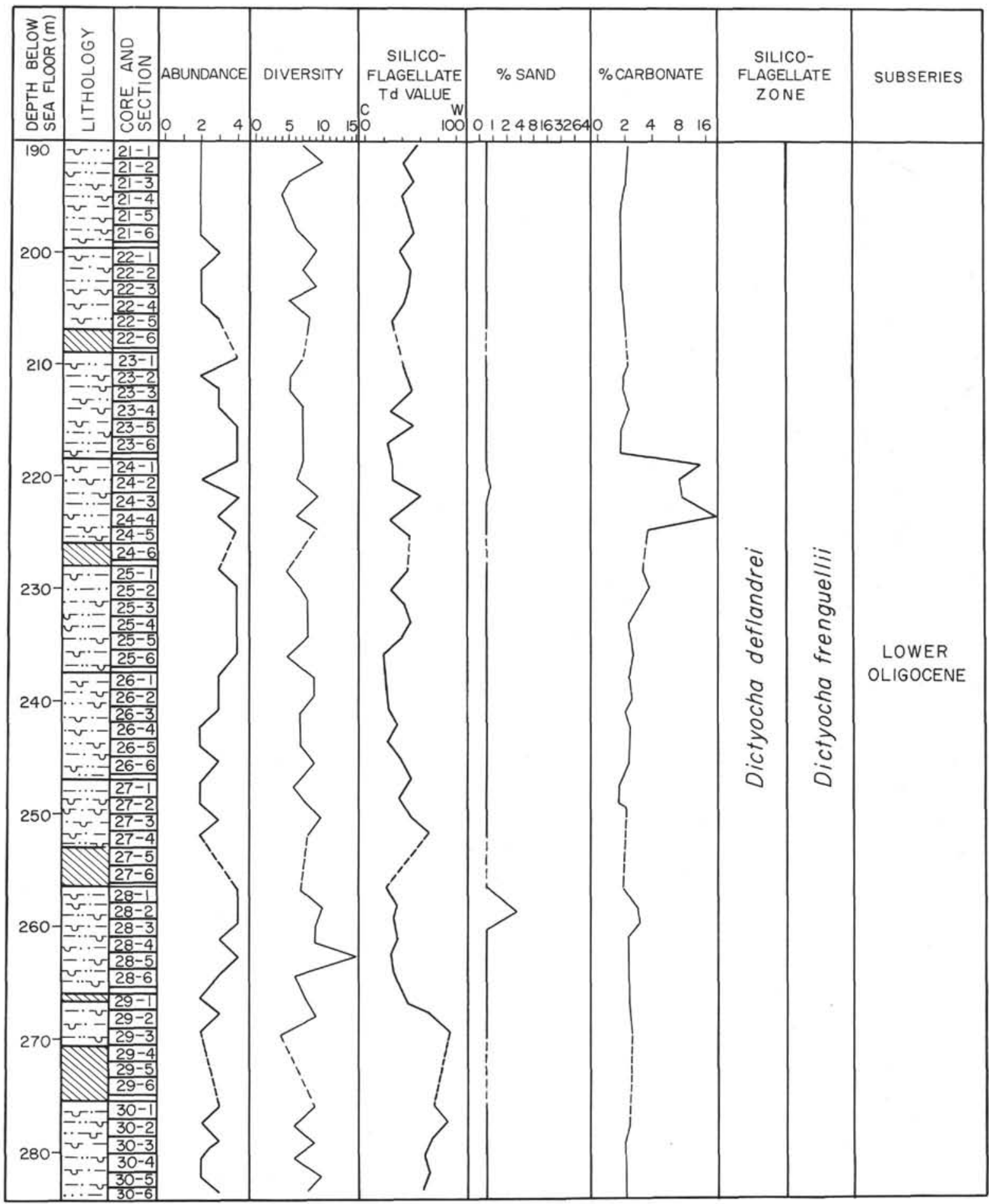

Figure 9c. Site 274 sand and carbonate percentages (Frakes, this volume) with silicoflagellate Td values, abundances, and diversities. Depths, lithologies, core and section numbers, silicoflagellate zones and subzones, and geologic subseries are indicated. For discussion of the data, see text.

\section{Dictyocha frenguellii Deflandre}

(Plate 6, Figures 3-9)

Dictyocha fibula Ehr. forma Deflandre, 1940, p. 598, fig. 2

Dictyocha frenguellii Deflandre, 1950c, p. 194, fig. 188-193.

Dictyocha frenguellii var frenguellii Glezer, 1966, p. 257, 258, pl. 11,

fig. 9.

Remarks: Specimens of Dictyocha frenguellii, from the early Oligocene Dictyocha deflandrei Zone at Site 274, exhibit several intraspecific variations of the apical apparatus (Plate 6, Figures 4-9). All variations are presently combined in occurrence tabulations as Dictyocha frenguellii s.l. until further analysis of the Dictyocha frenguellii group is made to determine the stratigraphic significance of the various morphotypes.

This species has previously only been reported from late Eocene or early Oligocene strata of the Soviet Union (Glezer, 1966). No specimens of $D$. frenguellii have been found in late Eocene or early Oligocene samples from Oamaru sections in New Zealand examined by the author or in Eocene deep-sea samples studied by Ling (1972). 


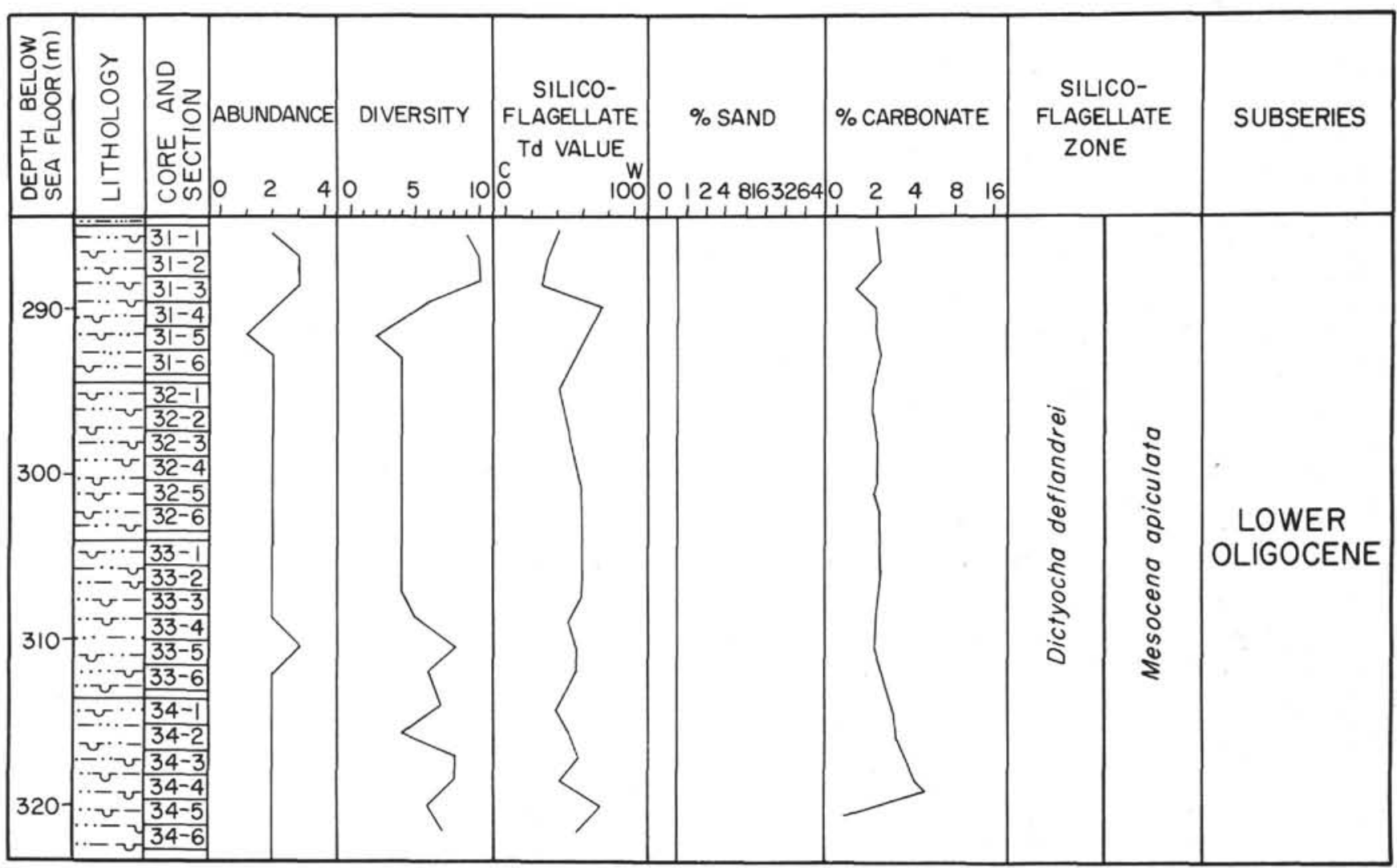

Figure 9d. Site 274 sand and carbonate percentages (Frakes, this volume) with silicoflagellate Td values, abundances, and diversities. Depths, lithologies, core and section numbers, silicoflagellate zones and subzones, and geologic subseries are indicated. For discussion of the data, see text.

Specimens have been observed in the early Oligocene section at Site 274 which have one to three apical spines and appear to be intermediary forms between $D$. deflandrei and $D$. frenguellii. The presence of such evolutionary intermediates and the younger stratigraphic position of $D$. frenguellii suggest that the species may have developed from the late Eocene-early Oligocene $D$. deflandrei stock.

\section{Dictyocha hexacantha Schulz}

(Plate 6, Figures 10, 11)

Dictyocha hexacantha Schulz, 1928, p. 255, fig. 43; Gemeinhardt; 1930, p. 55, 56, fig. 46; Hanna, 1931, p. 198, fig. 7; Glezer, 1966, p. 239 , pl. 10, fig. 12; Ling, 1972, p. 162, 163, pl. 26, fig. 3 .

Dictyocha deflandrei fa. hexacantha Frenguelli, 1940, p. 65 , fig. $14 \mathrm{~g}$. Corbisema hexacantha Deflandre, 1950a, p. 65-66, fig. 183-187.

Remarks: Rare occurrences of this species are noted in Cores 26 to 31 in the early Oligocene section at Site 274. It is also found reworked into Pleistocene sediments at the same site.

\section{Dictyocha medusa Haeckle, 1887}

Dictyocha medusa Haeckel, 1887, p. 1560, pl. 101, fig. 13, 14.

Remarks: This species is characterized by four lateral rods which merge at a central point. It has a four-sided basal ring and is easily differentiated from Dictyocha deflandrei by its larger size and conspicuous constrictions where lateral rods and basal ring merge. In the Antarctic it is only found in Pliocene aged sediments, particularly those of the Dictyocha pseudofibula Zone. In the Eastern Equatorial Pacific it is restricted to the Miocene (Bukry and Foster, 1973).

\section{Dictyocha mutabilis Deflandre \\ (Plate 7, Figures 1-5)}

Dictyocha mutabilis Deflandre, 1950c, p. 197, fig. 203-210.

Remarks: This species occurs commonly at Site 266 , Core 13 , and its interval of common occurrence at this site defines the Dictyocha mutabilis Zone. Its middle Miocene occurrence at Site 266 may be correlative with its occurrence in the middle Miocene (Helvetian) of San Pedro, California (Deflandre, 1950c).

\section{Dictyocha pentagona (Schulz) \\ (Plate 7, Figures 6, 7)}

Dictyocha fibula var. pentagona Schulz, 1928, p. 255, fig. 41a-b (fide Loeblich et al., 1968, p. 96, pl. 12, fig. 13, 14).

\section{Dictyocha perlaevis Frenguelli}

Dictyocha perlaevis Frenguelli, 1951, p. 279, fig. 4b, c (fide Loeblich et al., 1968, p. 40, 109, pl. 51, fig. 7, 8); Dumitrica, 1973, p. 848, 849, pl. 3 , fig. $8-12$, pl. 4 , fig. 1,2 ).

Remarks: The only occurrence of this species in the Antarctic is in the early Pliocene of the Distephanus boliviensis and Dictyocha pseudofibula zones.

\section{Dictyocha pseudofibula (Schulz)}

(Plate 7, Figures 8-11)

Distephamus speculum fa. pseudofibula Schulz, 1928, p. 262, 263, fig. $5 \mathrm{la}, \mathrm{b}$.

Dictyocha pseudofibula Tsumura, 1963, p. 55, pl. 11, fig. 1-3, pl. 24, fig. 2 . 
Dictyocha staurodon Ehrenberg

Dictyocha staurodon Ehrenberg, 1844a, p. 70, 80.

Remarks: In the present study, Dictyocha staurodon was only recovered from Site $266(20-3,60-62 \mathrm{~cm})$.

\section{Dictyocha variabilis (Hanna) n. comb.}

(Plate 7, Figures 12-15)

Distephanus variabilus Hanna, 1931, pl. D, fig. 8, pl. E, fig. 4-7.

Remarks: This species is characterized by a five-sided basal ring with spines radiating from each of the five corners and by a convex apical bridge which is usually without apical windows. All specimens observed lack an apical window and a majority of those specimens examined from the type locality also lack an apical window. The predominance of specimens lacking an apical window suggests that the rarer specimens with a window may in fact be cannopilean variations. This fact, coupled with the species' presence in warm-water assemblages with a high percentage of Dictyocha species is considered ample reason for a generic reassignment.

In the present study, Dictyocha variabilus is represented only rarely in the Dictyocha frenguellii Subzone of the early Oligocene Dictyocha deflandrei Zone. This species is also recorded in the late Eocene Kellogg, Kreyenhagen, and "Sidney Flat" shales (Mandra, 1968).

\section{Genus DISTEPHANUS Stöhr, 1880}

Distephanus boliviensis (Frenguelli)

(Plate 8, Figures 8, 9; Plate 9, Figures 1, 2)

Dictyocha boliviensis Frenguelli, 1940, p. 44, fig. 4 (fide Loeblich et al., 1968, p. 83, pl. 9, fig. 3).

Distephanus boliviensis Bukry and Foster, 1973, p. 827, pl. 4, fig. 1-3.

Remarks: This particularly large species is characterized by an open apical ring, a six- or seven-sided basal ring with or without basal accessory spines, and equant radial spines. Typical forms are prominent in the early Pliocene and portions of the late Pliocene.

Smaller forms, with two opposing basal ring spines longer than the other four, are referred to as Distephanus sp. cf. D. boliviensis in the occurrence charts. These forms have occurrences and abundances similar to those of $D$. boliviensis.

Forms of this species from the Dictyocha deflandrei Zone of Site 274 are similar to Pliocene specimens of $D$. boliviensis in general skeletal form, but have a thicker skeleton which usually exhibits a more prominent microstructure of subparallel ridges. Early Oligocene forms of this species are referred to as $D$. cf. $D$. boliviensis in the occurrence charts.

Distephanus boliviensis var. binoculus n. comb. (Plate 8, Figures 6, 7)

Dictyocha boliviensis f. binoculus Frenguelli, 1951, p. 276. Cannopilus binoculus Bukry and Foster, 1973, p. 825-826, pl. 1, fig. 1, 2.

Remarks: This variety is characterized by equant distal spines on a six or seven-sided basal ring and by two apical windows. Basal accessory spines are usually present on each side of the basal ring. The variety differs from Distephanus boliviensis only by the presence of two apical windows. Abundant $D$. boliviensis, found associated with $D$. boliviensis var. binoculus, exhibit a high degree of skeletal variability in the apical apparatus. The skeletal variability of $D$. boliviensis and the restricted occurrence of this variety, within the geologic range of $D$. boliviensis, are, in the author's opinion, an argument in favor of considering these multiwindowed forms as varieties of $D$. boliviensis. In addition, the differences between the range of two-windowed forms and specimens with three to five windows is considered sufficient reason for maintaining separate variety names for specimens with a multiwindowed apical apparatus.

Distephanus boliviensis var. major (Frenguelli) n. comb.

(Plate 8, Figures 1-5)

Dictyocha boliviensis var. major Frenguelli, 1951, p. 277, fig. 3a-c. Cannopilus major Bukry and Foster, 1973, p. 826, pl. 1, fig. 4-7, pl. 7, fig. 4.

Remarks: The present variety is characterized by equant distal spines on a six- or seven-sided basal ring and by three to five apical windows. Basal accessory spines are usually present on each side of the basal ring.

\section{Distephanus crux (Ehrenberg)}

(Plate 9, Figures 3-9)

Distephanus crux Ehrenberg, 1840 (fide Loeblich et al., 1968, p. 85, pl

8, fig. 29-32); Ehrenberg, 1854, pl. 18, fig. 56, pl. 33 (XV), fig. 9.

Remarks: Specimens of Distephanus crux from the early Oligocene at Site 274 exhibit a number of skeletal variations in basal ring size and shape, apical ring size, radial spine length, and ornamentation (see Plate 9, Figures 3-9). All skeletal variations are presently combined in occurrence tabulations as D. crux s.l. until further stratigraphic analysis of the various morphotypes is complete.

In the Antarctic, rare to few $D$. crux occur in early Pliocene to late Miocene aged sediments; however, in the Oligocene it is a major component of the silicoflagellate assemblage.

\section{Distephanus longispinus (Schulz)}

(Plate 9, Figure 10)

Distephanus crux f. longispina Schulz, 1928, p. 256, fig. 44.

Distephanus longispinus Bukry and Foster, 1973, p. 828, pl. 4, fig. 7, 8.

\section{Distephanus polyactis (Ehrenberg)}

(Plate 10, Figures 12-17)

Dictyocha polyactis Ehrenberg, 1839, p. 129.

Distephanus polyactis Deflandre, 1932b, p. 501, fig. 40.

Distephanus polyactis Dumitrica, 1973, p. 851-852, pl. 7, fig. 13, pl. 8, fig. 1-10.

Remarks: Distephanus polyactis ranges from the upper Distephanus speculum B Zone throughout the Distephanus speculum A Zone. An acme of this species occurs in the upper D. speculum B Zone, where it becomes a dominant component of the assemblage. The number of radial spines present varies from 7 to 13 , with the average number of radial spines being 8 or 9 .

Distephanus speculum (Ehrenberg)

(Plate 9, Figures 11, 12; Plate 10, Figures 1-3)

Distephanus speculum Ehrenberg, 1839, p. 129.

Remarks: This species exhibits a wide degree of intraspecific skeletal variability with basal ring spine lengths and apical ring diameters exhibiting the greatest and most frequent variability.

\section{Distephanus speculum var. pentagonus Lemmermann}

(Plate 10, Figures 4-8)

Distephanus speculum var. pentagonus Lemmermann, 1901, p. 264, pl. 11 , fig. 19.

Remarks: This species is found throughout the Pleistocene, Pliocene, and latest Miocene of most sites and rarely in the early Oligocene at Site 274. It is most common in intervals between the early Pliocene Distephanus boliviensis and Dictyocha pseudofibula zones.

Specimens from the Site 274 early Oligocene Dictyocha deflandrei Zone have a similar skeletal shape but are recorded as $D$. cf. $D$. speculum because of their thicker and wider skeleton, wider apical ring, and usually conspicuous surface ornamentation of subparallel ridges.

\section{Distephanus speculum var. pentagonus forma armatus Lemmermann} (Plate 10, Figures 9, 10)

Distephanus speculum var. pentagonus forma armatus Lemmermann, 1901 , p. 264 , pl. 11, fig. 20.

Remarks and measurements: This form has a symmetric five-sided basal and apical ring and is differentiated from the type variety by the presence of one to three very prominent spines on the apical ring. Measurements are: Basal ring $20-25 \mu$ wide, apical ring $10 \mu$ wide and length of apical spines $5-10 \mu$.

This species was found to occur abundantly at Site 266 between Samples 6-6, 120-122 cm and 7-3, 50-52 cm. Its acme serves as a useful datum in the late Pliocene, as it closely approximates the Distephanus speculum Zone B-Distephanus boliviensis Zone boundary.

\section{Distephanus speculum var. pentagonus f. geminus n.f.} (Plate 10, Figure 11)

Description and measurements: Basal ring is pentagonal with straight sides, $15-25 \mu$ long, which may or may not possess basal accessory spines. Two relatively low-standing apical rings are connected to the basal ring by five straight lateral rods. Five long, $10-15 \mu$, tapering 
radial spines project on the plane of the basal ring or curve slightly abapically.

Occurrence: The stratigraphic occurrence of this new form is apparently restricted to early Pliocene sedimentary sequences, with a few specimens noted in the Dictyocha pseudofibula Zone at Site 274 and the Distephanus boliviensis and Dictyocha aspera var. pygmaea-D. fibula var. pumila zones at Site 266.

Type specimen: The holotype (Plate 10, Figure 11) will be deposited at the USNM. The type number has not yet been assigned but will be published in Contribution 41 of the Florida State University Sedimentological Research Laboratory.

\section{Distephanus speculum var. septenarius (Ehrenberg)}

Dictyocha speculum var. septenaria Hovassee, 1946, p. 9.

Distephanus speculum var. septenarius Jorgensen, 1899, p. 50.

Genus MESOCENA Ehrenberg, 1843, emend. Deflandre, 1950

Mesocena apiculata (Schulz)

(Plate 11, Figures 1-5)

Mesocena apiculata Deflandre, 1932b, p. 499, fig. 34, 35.

\section{Mesocena diodon Ehrenberg}

(Plate 12, Figures 1-3)

Mesocena diodon Ehrenberg, 1844a, p. 71, 84 (fide Loeblich et al., 1968, p. 54, 128); Ehrenberg, 1854, pl. 33, fig. 18; Loeblich et al., 1968, pl. 27 , fig. 4 .

Mesocena cremulata var. diodon Lemmermann, 1901, p. 255, pl. 10, fig. 1, 2; Schulz, 1928, p. 236, fig. lab; Gemeinhardt, 1930, p. 26, fig. 10a, non lob; Deflandre, 1932a, fig. 4.

Mesocena elliptica diodon Dumitrica, 1972, p. 905, pl. 1, fig. 3.

Remarks: This circular to elongate elliptic species is usually $50-60 \mu$ in length and has two, $2-10 \mu$, distal spines aligned with the major axes. The surface ornamentation is usually comprised of prominent transverse crests but may also have a pustulate appearance.

The present study agrees with Dumitrica's observation that forms meeting the present description have a short geologic range and occur independently or greatly outnumber the four-spined Mesocene elliptica forms. These reasons are considered to be sufficient to favor maintaining $M$. diodon as an independent taxon of specific or subspecific rank.

$M$. diodon has been recorded in Eltanin piston core stratigraphic sequences of the early Gilbert magnetic epoch, below event "c" ( $\sim 4.65$ m.y. B.P.) and also in a probable Epoch 5 (late Miocene) sequence. In this study $M$. diodon was only found in early Pliocene sections at Sites $266,267 \mathrm{~B}$, and 269 , with the exception of very rare occurrences in the late Miocene at Site 274. The general lack of late Miocene occurrences is in part due to very poor recovery of sediment of this age.

$M$. diodon has also been recorded from the middle and upper Miocene at Site 206 in the Tasman Basin and Site 33 in the northeastern Pacific (Dumitrica, 1973), the experimental Mohole drilling (Ling, 1972), and Sites 157-158 from the Panama Basin area (Bukry and Foster, 1973).

\section{Mesocena circulus (Ehrenberg)}

(Plate 11, Figures 6, 8, 9)

Dictyocha circulus Ehrenberg, 1840, p. 208.

Mesocena circulus Ling, 1972, p. 175, 176, pl. 28, fig. 5, 6.

\section{Mesocena elliptica Ehrenberg}

Remarks: Mesocena elliptica was rarely noted to occur in the lower Pliocene Mesocena diodon Zone at Site 266, the Distephanus boliviensis Zone of El 36-33 and 50-28, and Dictyocha aspera var. pygmaea-D. fibula var. pumila Zone of E 50-28.

Two and three-spined varieties occur abundantly in lower Pliocene Eltanin cores and in the Distephanus boliviensis and Dictyocha aspera var. pygmaea-D. fibula var. pumila zones at Site 266 . These specimens are unlike $M$. diodon and are very likely two and three-spined varieties of $M$. elliptica. In the present paper such forms are considered as Mesocena cf. elliptica.

\section{Mesocena oamaruensis Schulz}

(Plate 12, Figure 11)

Mesocena oamaruensis Schulz, 1928, p. 240, fig. 10a, b; Gemeinhardt, 1930, p. 34, fig. 20; Deflandre, 1932a, fig. 11; Tsumura, 1959, p. 56, pl. 2, fig. 22; Ling, 1972, p. 179, 180, pl. 29, fig. 8-10; Glezer, 1966, p. 285 , pl. 28 , fig. 3 .

Corbisema oamaruensis Frenguelli, 1940, p. 64, fig. 13c.

Not Mesocena oamaruensis Stradner, 1961, p. 89, fig. 30, 31; Tsumura, 1963 , p. 43, pl. 7, fig. 2; pl. 21, fig. 12; Bachmann, 1964, pl. 4, fig. 37.

Remarks: Specimens assigned to this species have a smooth, roundly triangular basal ring, without basal or accessory spines. Most specimens also have a complete lumen without septa.

Rare to common abundances of this species occur throughout most of the early Oligocene at Site 274 between Cores 21 and 34. It also occurs more rarely in the late Oligocene Cores 4 and 5 at Site 267. Mesocena oamaruensis is known to occur elsewhere: in late Eocene samples from the Oamaru Diatomite of New Zealand, the Kellogg and Sidney shales of California (Ling, 1972), and the Oligocene of the Soviet Union (Glezer, 1966). Its total stratigraphic range as presently known is, thus, late Eocene through late Oligocene.

\section{Mesocena oamaruensis var. quadrangula Schulz} (Plate 12, Figure 7)

Mesocena oamaruensis var. quadrangula Schulz, 1928, p. 240, fig. 12.

Remarks: In the present study, only rare occurrences of the present species were observed in the late Eocene at Site $264(2$, CC) and in the late Oligocene Naviculopsis biapiculata Zone at Site 267 (4-4, 120-122 $\mathrm{cm}$ and $4-6,120-122 \mathrm{~cm}$ )

\section{Mesocena pappi Bachmann (Plate 12, Figure 8)}

Mesocena pappi Bachmann, 1962, p. 380, pl. 1, fig. 1-9; Ling, 1973, p. 753, pl. 3, fig. 5,6 .

Remarks: This rather rare species was only recovered from the three following early Miocene samples, Site $266(19-1,60-62 \mathrm{~cm}$ and $20-3,60-62 \mathrm{~cm})$ and Site $272(35, \mathrm{CC})$. This species was originally described from the Eocene Kreyenhagen Shale of California and was recorded in the early Miocene of Site 186 (Ling, 1973), which is located in the North Pacific.

\section{Genus NAVICULOPSIS Frenguelli, 1940 \\ Naviculopsis biapiculata (Lemmermann) (Plate 12, Figures 9-11)}

Dictyocha navicula var. biapiculata Lemmermann, 1901, p. 258, pl. 10, fig. 14,15 .

Naviculopsis biapiculata Ling, 1972, p. 181, pl. 30, fig. 1-4.

\section{Naviculopsis constricta (Schulz)}

Dictyocha navicula var. biapiculata fa. constricta Schulz, 1928, p. 246, fig. 21.

Naviculopsis biapiculata var. constricta Glezer, 1966, p. 257, 258, pl. 17, fig. 4 .

Naviculopsis constricta Ling, 1972, p. 183-184, pl. 30, fig. 5-8.

Remarks: The present taxa was observed from a single, late Eocene sample $(2, \mathrm{CC})$ from Site 264.

\section{Naviculopsis lata (Deflandre)}

Dictyocha biapiculata var. lata Deflandre, 1932b, p. 500, fig. 300, 301. Dictyocha lata Bachmann, 1970, p. 278, 279, pl. 2, fig. 1-20; pl. 3, fig. 1-15, Ling, 1972, p. 185, 186, pl. 30, fig. 12-16.

\section{Naviculopsis navicula (Ehrenberg)} (Plate 13, Figure 1)

Dictyocha navicula Ehrenberg, 1839, p. 129; Ehrenberg, 1854, pl. 20, fig. 43; Haeckel, 1887, p. 1559; Lemmermann, 1901, pl. 10, fig. 12, 13; Lemmermann, 1903, p. 27, fig. 90; Schulz, 1928, p. 243, fig. 166; Gemeinhardt, 1930, p. 35, 36, fig. 22.

Dictyocha ponticulus Ehrenberg, 1844c, p. 267; Bailey, 1845, p. 328, pl. 4 , fig. 21.

Naviculopsis navicula Deflandre, 1950a, p. 77, fig. 241, 243; Stradner, 1961, p. 89, fig. 47; Bachmann, 1970, fig. 2b; Ling, 1972, p. 186, 187 , pl. 30 , fig. $17-19$, pl. 31 , fig. 1 .

Not Dictyocha navicula Glezer, 1966, p. 233, 235, pl. 9, fig. 4, 5 .

Naviculopsis navicula var. naviculopsis (Deflandre) (Plate 13, Figures 2, 3)

Dictyocha navicula var. naviculopsis Tsumura, 1963, p. 44, pl. 7, fig. 5. 
Naviculopsis regularis (Carnevale)

(Plate 13, Figures 4-7)

Dictyocha regularis Carnevale, 1908, p. 35, pl. 4, fig. 28.

Dictyocha ausonia var. regularis Deflandre, 1950a, p. 68-69, fig. 198 (only).

Naviculaopsis regularis Ling, 1972, p. 188, 189, pl. 31, fig. 3-5.

\section{Naviculopsis robusta Deflandre}

(Plate 13, Figures 8-12)

Naviculopsis robusta Deflandre, 1950c, p. 202, fig. 227-230; Glezer, 1966, p. 273 , pl. 16, fig. 1, pl. 33, fig. 3-6.

\section{Naviculopsis trispinosa (Schulz)}

(Plate 13, Figures 13, 14)

Dictyocha navicula var. trispinosa Schulz, 1928, p. 246-247, fig. 23a,b; Gemeinhardt, 1930, p. 40, fig. 27; Deflandre, 1932a, fig., 24; Tsumura, 1963, p. 46, pl. 8, fig. 4-6.

Naviculopsis biapiculata fa. trispinosa Frenguelli, 1940, fig. 11e.

Naviculopsis trispinosa Glezer, 1966, p. 258, 259, pl. 17, fig. 7; Ling, 1972 , p. 190 , pl. 31, fig. $7,8$.

Remarks: Naviculopsis trispinosa was found to be rare in the late Oligocene Naviculopsis biapiculata Zone at Site 267 (Cores 4 and 5) and rare or abundant throughout the early Oligocene Dictyocha deflandrei Zone at Site 274 (Cores 20-34). An acme of this species occurs in the Dictyocha deflandrei Zone (Core 25) that provides a useful datum within the Dictyocha frenguellii Subzone.

\section{ACKNOWLEDGMENTS}

I would like to express my appreciation to my major professor, Sherwood W. Wise, and Leg 28 chief scientists Lawrence A. Frakes and Dennis E. Hayes for providing me with the opportunity to write this shore-laboratory report. All research was carried out at the Antarctic Marine Geology Research Facility at Florida State University. A special thanks goes to Dennis S. Cassidy for his photographic and repeated logistical assistance. Thanks is also extended to Deborah L. Delfel for photographic assistance, Rosemarie Raymond for drafting, and Yang-Ja Chung for valuable assistance in sample processing. I also wish to thank Norman D. Watkins for paleomagnetic information on selected Eltanin piston cores and Lawrence A. Frakes for Site 274 carbonate and quartz data. Sherwood W. Wise, Menno G. Dinkelman, Richard E. Casey, and John H. Mercer critically read portions of the manuscript. My sincere appreciation is expressed to my associates Fred M. Weaver and David W. McCollum for many long and fruitful hours of discussion on Southern Ocean biostratigraphy and paleoclimatology. Deep Sea Drilling Project and Eltanin samples were supplied courtesy of the National Science Foundation.

\section{REFERENCES}

Bachmann, A., 1962. Eine neue Mesocena-Art (Silicoflagellidae) aus dem Kalifornischen Eozan: Verh. Geol. Burdesanstalt, v. 1962, p. 378-383. 1964. Part II. Silicoflagellidae und Archaeomonadaceae. In Ichikawa, W. et al., Fossil diatoms, pollen grains and spores, silicoflagellates and archaeomonads in the Miocene Hojuji diatomaceous mudstone, Noto Peninsula, Central Japan: Kanazawa Univ., Sci. Rept., v. 12, no. 1, p. 87-118.

, 1967. Part II. Silicoflagellate im Iida Diatomit. In Ichikawa, W., Shimizu, I., and Bachmann, A., Fossil silicoflagellates and their associated uncertain forms in lida Diatomite, Noto Peninsula: Kanazawa Univ., Sci. Rept., v. 12 , no. 1 , p. $149-172$.

1970. Silicoflagellaten aus dem oberösterreichischen Egerien (Oberoligozän): Verh. Geol. B-A., Jahrg. 1970 , no. 2 , p. $275-305$.
Bailey, J.W., 1845. Notice of some new localities of Infusoria, fossil and Recent: Am. J. Sci. Arts, v. 48, no. 2, p. 321-343.

Bandy, O.L., Casey, R.E., and Wright, R.C., 1971. Late Neogene planktonic zonation, magnetic reversals, and radiometric dates, Antarctic to the tropics. In Reid, J.L., (Ed.), Antarctic Oceanography 1, Antarctic Research Series, v. 15: Washington (American Geophysical Union), p. 1-26.

Bukry, D., 1973. Coccolith and silicoflagellate stratigraphy, Deep Sea Drilling Project Leg 18, eastern North Pacific. In Kulm, L.D. and von Huene, R., et al., Initial Reports of the Deep Sea Drilling Project, Volume 18: Washington (U.S. Government Printing Office), p. 817-831.

Bukry, D. and Foster, J.H., 1973. Silicoflagellate and diatom stratigraphy, Leg 16, Deep Sea Drilling Project. In Winterer, E.L., et al., Initial Reports of the Deep Sea Drilling Project, Volume 16: Washington (U.S. Government Printing Office), p. 815-870.

Bull, C. and Webb, P.N., 1973. Some recent developments in the investigation of the glacial history and glaciology of Antarctica. In van Zinderen Bakker, E.M., (Ed.), Palaeoecology of Africa and of the surrounding islands and Antarctica: Cape Town, (Balkema), v. 8, p. 55-84.

Carnevale, P., 1908. Radiolarie e silicoflagellati de Bergonzano (Reggio Emilia): R. Ist. Veneto Sci. Lett. Atri. Mem., v. 28 , no. 3 , p. $1-46$.

Ciesielski, P.F., 1974. Southern Ocean silicoflagellate paleotemperatures based upon Dictyocha to Distephanus ratios: Antarctic J. U.S. v. 9.

Ciesielski, P.F. and Weaver, F.M., 1973. Southern Ocean Pliocene paleotemperatures based on silicoflagellates from deep-sea cores: Antarctic J. U.S., v. 8, no. 5, p. 295-297.

Deflandre, G., 1932a. Les Silicoflagelles des terres fossiles a Diatomees: Soc. France Microsc. Bull., v. 1, no. 1, p. 1020.

1932b. Sur la systematique des Silicoflagelles: Soc. Bot. France Bull., v. 79, p. 494-506.

1940. Sur une structure reticulee meconnue du squellete des Silicoflagellidees: C.R. Acad. Sci. Paris, v. 211 , p. 597-599.

1950a. Contribution a l'etude des Silicoflagellides actuels et fossiles: Microscopie, v. 2, p. 72-108.

1950b. Contribution a l'etude des Silicoflagellides actuels et fossiles: Microscopie, v. 2, p. 117-142.

1950c. Contribution a l'etude des Silicoflagellides actuels et fossiles (Suite et fin): Microscopie, v. 2, p. 191-210.

Dumitrica, P., 1973. Paleocene, Late Oligocene and PostOligocene Silicoflagellates in Southwestern Pacific sediments on DSDP Leg 21. In Burns, R.E., Andrews, J.E., et al., Initial Reports of the Deep Sea Drilling Project, Volume 21: Washington (U.S. Government Printing Office), p. 819-883.

Ehrenberg, C.G., 1839. Über die Bildung der Kreidefelsen und des Kreidemergels durch unsichtbare Organismen: K. Akad. Wiss. Berlin, Abh. 1838, p. 59-148.

, 1840. Polygastrica Bacillaria: Ber. Uerhandl. König. Akad. Wiss., Berlin, p. 207-208.

, 1844a. Über 2 neue Lager von Gebirgsmassen aus Infusorien: Verh. K. Preuss. Akad. Wiss. Berlin. Ber., Jahrg. 1844, p. 57-97.

Ehrenberg, C.G., 1844b. Untersuchungen über die kleinsten Lebensformen im Quellenlande des Euphrats und Araxes, so wie über eine neuen Formen sehr reiche marine Tripelbildung von den Bermuda-Inseln vor: Verh. K. Preuss. Akad. Wiss. Berlin, Ber., Jahrg. 1845, p. 253-275. 1854. Mikrogeologie, das Erden und Felsen schaffende Wirken des unsichtbar kleinen selbstandigen Lebens auf der Erde: Leipzig (Leopold Voss), p. 1-374. 
Frenguelli, J., 1940. Consideraciones sobre los Silicoflagellados fosiles: Extracto de la Revista del Museo de la Plata (Nueva Serie), Seccion Paleontologia, v. 2, p. 37-112. 1951. Silicoflagelados del Tripolide Mejillones (Chile): Physis., v. 20, p. 272-284

Gemeinhardt, K., 1930. Silicoflagellatae. In Rabenhorst, L. (Ed.), Kryptogamen-Flora von Deutschland, Osterreich und der Schweiz: Leipzig (Akademische Verlagsgesellschaft), v. 10, pt. 2, p. 1-87.

1831. Organismenformen auf der Grenze zwischen Radiolarien und Flagellaten: Deutsch. Bot. Ges., Ber., v. 49 , no. 2 , p. $103-110$.

1934. Die Silicoflagellaten des Sudatlantischen Ozeans: Wiss. Ergebn. dt. atlant. Exped. "Meteor" $1925-$ 1927. (Biol. Sonderuntersuch.), pt. 1, v. 12 , no. 3, p. $274-$ 312 .

Glezer, Z.I., 1960. Paleogenovye kremnevye zhgutikovye vodorosli: Informatsionnyi Sbornik VSEGEI, no. 10, p. 103-113.

1966. Silicoflagellatophyseae. In Gollerbakh, M.M. (Ed.), Cryptogamic plants of the U.S.S.R.: Akad. Nauk SSSR, V. A. Komarova Bot. Inst. (Translated from Russian by Israel Program for Scientific Translations Ltd., Jerusalem, 1970), v. 7, p. 1-363.

Gordon, A.L. and Goldberg, R.D., 1970. Circumpolar characteristics of Antarctic waters. In Bushnell, V.C. (Ed.), Antarctic Map Folio Series: American Geographical Soc., folio 13, p. 2.

Haeckel, E., 1887. Report on the Radiolaria collected by H.M.S.Challenger during the years 1873-1876: Rept. Voy. Challenger, Zool., v. 18, p. 1-1803.

Hanna, G.D., 1931. Diatoms and silicoflagellates of the Kreyenhagen Shale: Mining in Calif., p. 197-201.

Hovasse, R., 1946. Flagelles a squelette siliceux: Silicoflagelles et Ebriides provenant du plancton recueilli au cours des campagnes scientifiques du Prince Albert ler de Monaco (1885-1912): Resultats des Campagnes Scientifiques, Monaco, fascicule 107, p. 1-20.

Jendrzejewski, J.P. and Zarillo, G.A., 1971. Late Pleistocene paleotemperatures: Silicoflagellates and foraminiferal frequency changes in a Subantarctic deep sea core: Antarctic J. U.S., v. 6, p. 178-179.

Jörgensen, E., 1899. Protophyten und Protozoen im Plankton aus der Norwegischen Westküste. Bergens Mus. Arb., no. 6, p. 1-110.

Kanaya, T. and Koizumi, 1966. Interpretation of diatom thanatocoenoses from the North Pacific applied to a study of core V20-130: Tohoku Univ. Sci. Repts., v. 37, p. 89130.

Lemmermann, E., 1901. Silicoflagellatae. Ergebnisse einer Riese nach dem Pacific., H. Schavinsland 1896/94: Deut. Bot. Ges., Ber., v. 19, no. 1, p. 247-271.

1903. Klasse Silicoflagellatae. In Brandt, K. and Apstein, C. (Eds.), Nordisches plankton: (Botanischer Teil), no. 21, p. 25-32.

Ling, H.Y., 1970. Silicoflagellates from central North Pacific core sediments: Am. Paleontol. Bull., v. 58, p. 84-127. 1972. Upper Cretaceous and Cenozoic silicoflagellates and ebridians: Am. Paleontol. Bull., v. 62, p. 135-229.

1973. Silicoflagellates and ebridians from Leg 19, Deep Sea Drilling Project. In Creager, J.S. and Scholl, D.W., et al., Initial Reports of the Deep Sea Drilling Project, Volume 21: Washington (U.S. Government Printing Office), p. 751-775.

Loeblich, A. R., 3d, Loeblich, L.A., Tappan, H., and Loeblich, A.R., Jr., 1968. Annoted index of fossil and recent silicoflagellates and ebridians with descriptions and illustrations of validly proposed taxa: Geol. Soc. Am. Mem. 106.

Lohmann, H., 1919. Die Bevolkerung des Ozeans mit Plankton nach den Ergebnissen der Zentrifugen Fange wahrend der Ausreise der "Deutschland": Berlin, Arch. Biontol., v. 4, p. 1-617.

Mandra, Y.T., 1958. Fossil silicoflagellates from California, Ph.D. thesis, Stanford University.

1968. Silicoflagellates from the Cretaceous, Eocene, and Miocene of California, U.S.A.; Calif. Acad. Sci. Proc., v. 36 , no. 9 , p. 231-277.

Mandra, Y.T. and Mandra, H., 1969. Silicoflagellates: A new tool for the study of Antarctic Tertiary climates: Antarctic J. U.S., v. 4, p. 172-174.

Martini, E., 1971. Neogene silicoflagellates from the equatorial Pacific. In Winterer, E.L., et al., Initial Reports of the Deep Sea Drilling Project, Volume 7: Washington (U.S. Government Printing Office), p. 1695-1708.

1972. Silicoflagellate zones in the late Oligocene and early Miocene of Europe. Senckenb. Lethaea., v. 45, p. 119 122 .

McSaveney, M.H., and McSaveney, E.R., 1972. A reappraisal of the Pecten glacial episode, Wright Valley, Antarctica: Antarctic J. U.S., v. 7, p. 235-240.

Mercer, J.H., 1968. Antarctic ice and Sangamon sea level: International Assoc. of Scientific Hydrology, General Assembly of Berne, Pub. 79, p. 217-225.

1973. Cainozoic temperature trends in the southern hemisphere: Antarctic and Andean glacial evidence, in van Zinderen Bakker, E.M. (Ed.), Palaeoecology of Africa and of the surrounding Islands and Antarctica: Cape Town (Balkema), v. 8, p. 85-114.

Mercer, J.H., Fleck, R.J., Mankinen, E.A., and Sander, W., in press. Southern Argentina: Glacial events between 4 m.y. and 1 m.y. ago. Royal Soc. New Zealand, Bull. 13.

Opdyke, N.D., 1972. Paleomagnetism of deep sea cores: Rev. Geophys. Space Phys., v. 10, no. 1, p. 213-249.

Sanfilippo, A., Burckle, L.H., Martini, E., and Riedel, W.R., 1973. Radiolarians, diatoms, silicoflagellates and calcareous nannofossils in the Mediterranean Neogene: Micropaleontology, v. 19, no. 2, p. 209-234.

Schulz, P., 1928. Beitrage zur Kenntnis fossiler und rezenter Silicoflagellaten: Bot. Archiv., v. 21, no. 2, p. 225-292.

Stöhr, E., 1880. Die Radiolarienfauna der Tripoli von Grotte, Provinz Girgenti in Sicilien: Paleontographica, v. 26, p. $69-$ 124.

Stradner, H., 1961. Uber fossile Silicoflagelliden und die Moglich-keit ihrer Verwendung in der Erdolstratigraphie: Erdol und Kohle, v. 14, no. 2, p. 87-92.

Tolstikov, Ye. I., ed., et al., 1966. Atlas Antarktiki I, Moscow: Leningrad Glavnoge Uprauleniye Geodezii i Kantografii.

Tsumura, K., 1959. Komentariita figuraro de Silikoflageluloj: Yokohama Municipal Univ., Bull., v. 11, Nat. Sci., v. 1, p. $35-90$.

1963. A systematic study of Silicoflagellatae. J. Yokohama Municipal Univ. ser. C-45, v. 146, p. 1-84.

Weaver, F.M., 1973. Pliocene paleoclimatic and paleoglacial history of East Antarctica recorded in deep sea piston cores: Sedimentology Research Laboratory, Department of Geology, Florida State Univ., Contrib. 36.

Weaver, F.M. and Ciesielski, P.F., 1973. Pliocene paleoclimatic history recorded in Antarctic deep sea cores: Geol. Soc. Am., Abstracts with Programs, p. 856-857. 
Webb, P.N., 1972. Wright Fjord, Pliocene marine invasion of an Antarctic dry valley: Antarctic J. U.S., v. 7, p. 225-232. Weissel, J.K. and Hayes, D.E., 1973. Asymmetric seafloor spreading south of Australia: Nature, v. 231, no. 5304, p. 518-522.
Worsley, T.R. 1973. Calcareous nannofossils: Leg 19 of the Deep Sea Drilling Project. In Creager, J.S., Scholl, D.W., et al., Initial Reports of the Deep Sea Drilling Project, Volume 19, Washington (U.S. Government Printing Office), p. 741-750. 


\section{PLATE 1}

Silicoflagellate photomicrographs; $615 \times$

Figures 1-9 Cannopilus antarcticus n. sp.

1. Sample 266-17-5, 65-67 cm, low focus.

2. Same, high focus.

3. Sample 266-17-5, 65-67 cm, low focus.

4. Same, high focus.

5. Sample 266-17-5, 65-67 cm, low focus.

6. Same, high focus.

7. Sample 266-17-5, 65-67 cm, low focus.

Holotype.

8. Same, intermediate focus.

9. Same, high focus. 
PLATE 1
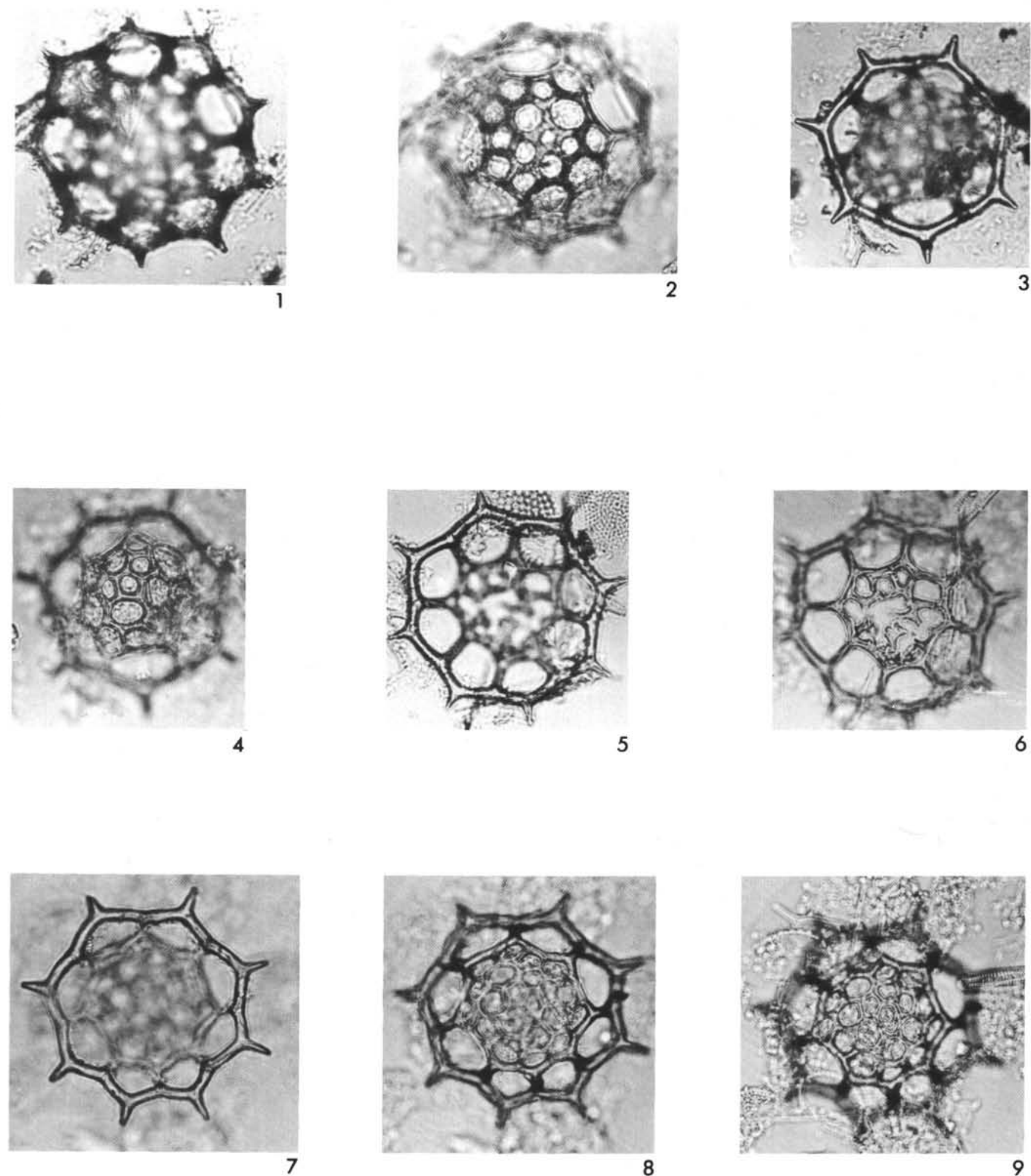

3
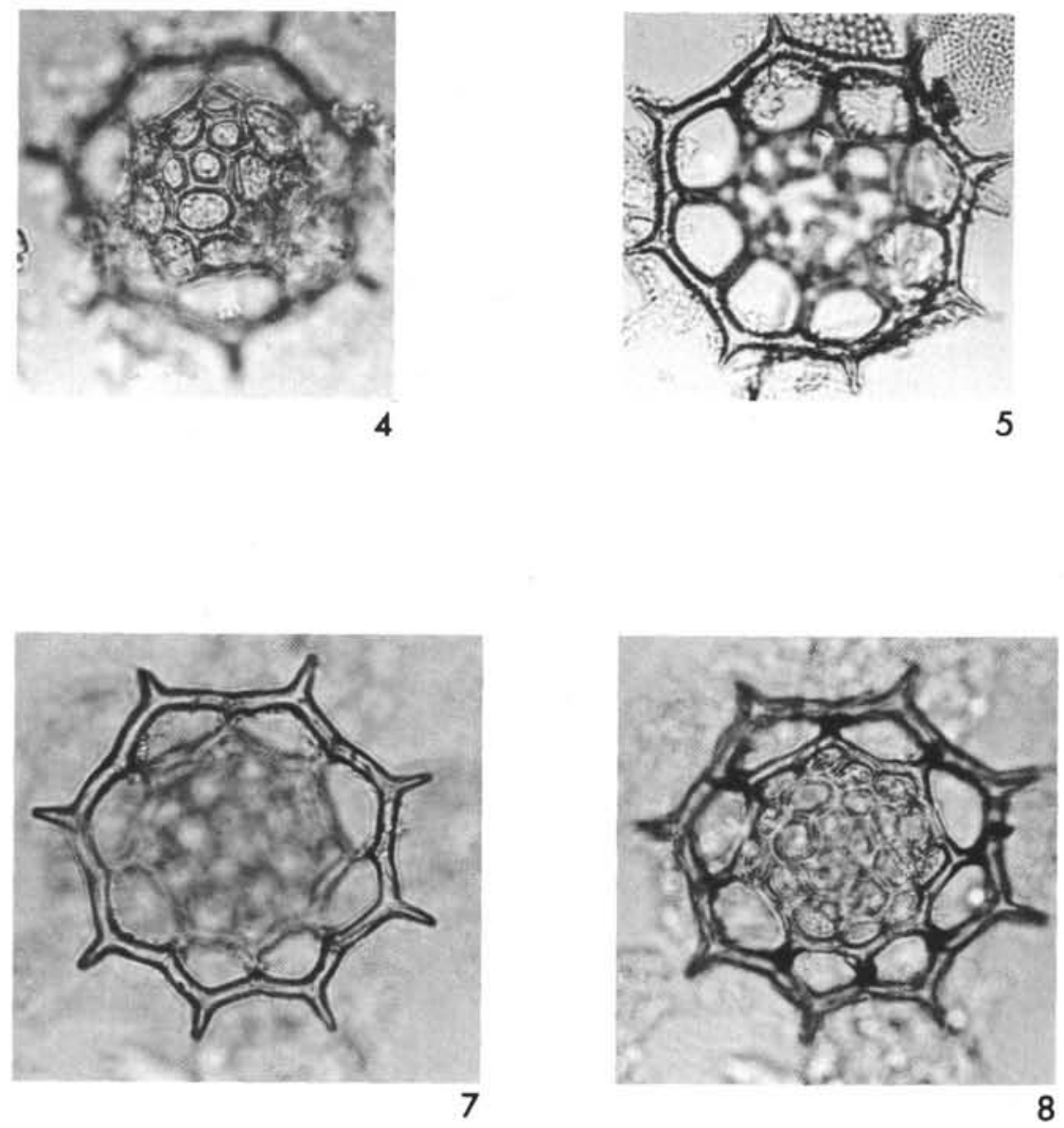


\section{PLATE 2}

Silicoflagellate photomicrographs; $615 \times$ (except Figure 1 which is $1395 \times$ )

Figures 1-3 Cannopilus hemisphericus (Ehrenberg).

1. Sample 266-8-2, 120-122 cm.

2. Sample 266-17-5, 65-67 cm.

3. Sample $266-17-5,65-67 \mathrm{~cm}$.

Figures 4-11 Corbisema apiculata (Lemmermann).
4. Sample 274-23-5, $80-82 \mathrm{~cm}$.
5. Sample 274-23-5, 80-82 cm.
6. Sample 274-23-2, 30-32 cm.
7. Sample $274-23-5,80-82 \mathrm{~cm}$.
8. Sample 274-21-6, 30-32 cm.
9. Sample 274-23-2, 30-32 cm.
10. Sample 274-21-6, $30-32 \mathrm{~cm}$.
11. Sample $274-23-5,80-82 \mathrm{~cm}$.

Figures 12-15 Corbisema hastata (Lemmermann).

12. Sample 274-28-1, 30-32 cm.

13. Sample 274-23-5, $80-82 \mathrm{~cm}$.

14. Sample 274-20-1, 30-32 cm.

15. Sample $274-21-2,30-32 \mathrm{~cm}$. 
PLATE 2
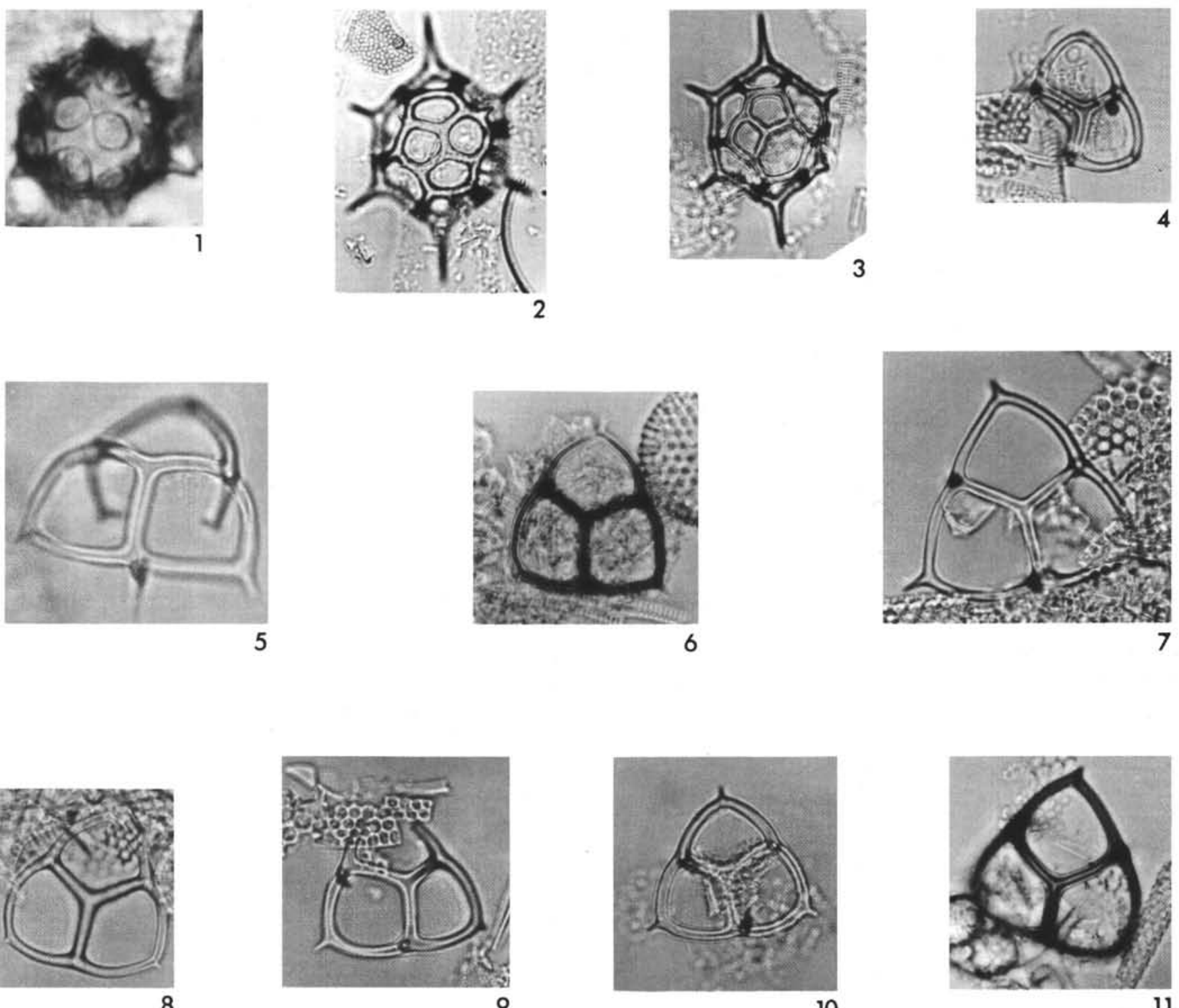

8
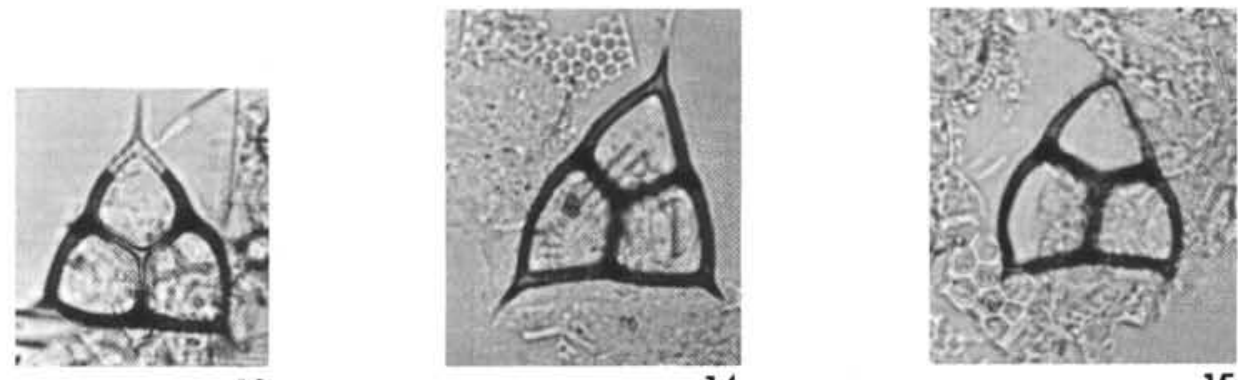
P. F. CIESIELSKI

\section{PLATE 3}

Silicoflagellate photomicrographs; $615 \times$.

Figures 1, 2 Corbisema archangeiskiana (Schulz).

1. Sample 267-4-4, 120-122 cm.

2. Sample $267-4-4,120-122 \mathrm{~cm}$.

Figures 3-6 Corbisema triacantha Ehrenberg.

3. Sample 274-24-1, $58-60 \mathrm{~cm}$.

4. Sample 274-23-3, 30-32 cm.

5. Sample 266-17-4, 60-62 cm.

6. Sample 266-17-5, 65-67 cm.

Figure $7 \quad$ Corbisema ? sp.

Sample 274-27-3, 130-132 cm.

Figure $8 \quad$ Corbisema triacantha var. flexuosa Stradner.

Sample 266-20-3, 60-62 cm.

Figure $9 \quad$ Corbisema spinosa Deflandre.

Sample 274-26-6, 30-32 cm.

Figures 10, 11 Dictyocha aspera (Lemmermann).

10. Sample E $38-8,480-482 \mathrm{~cm}$.

11. Sample $269-8-4,45-47 \mathrm{~cm}$. 
PLATE 3
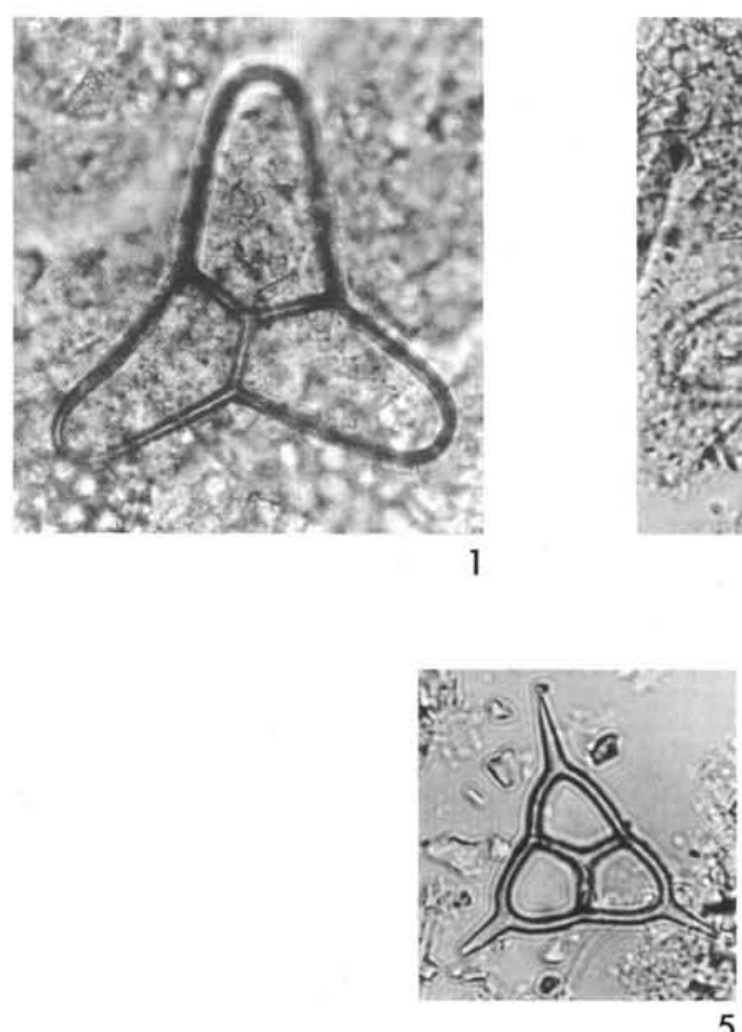

5
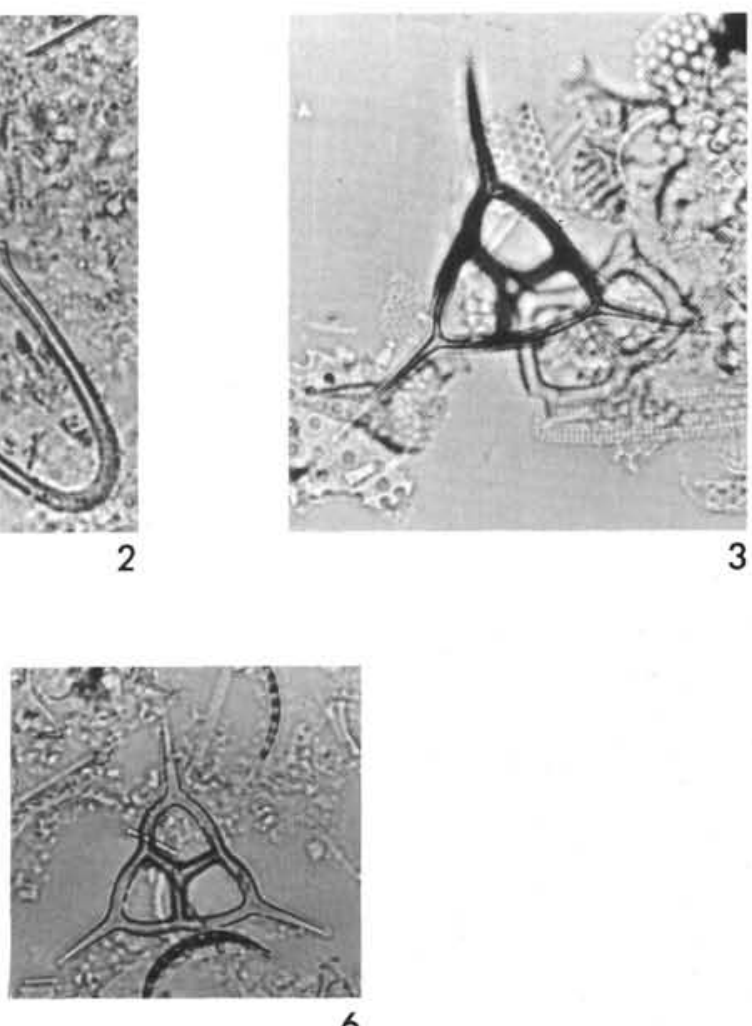
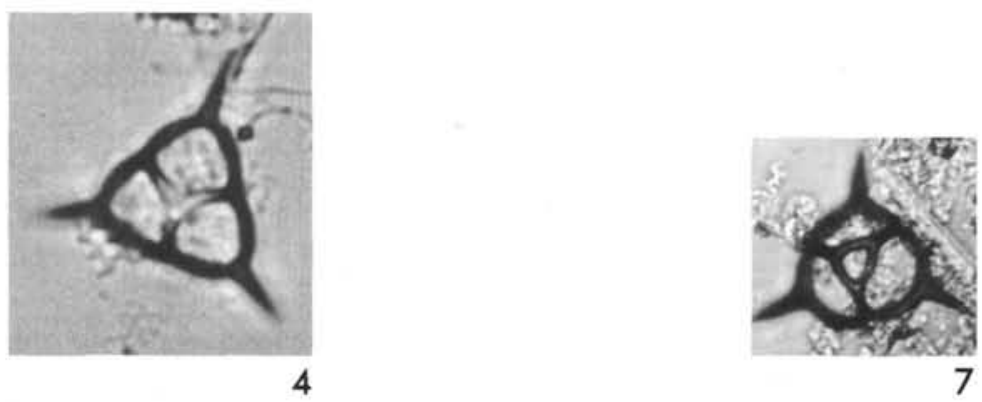

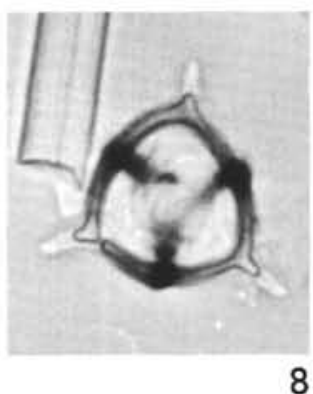

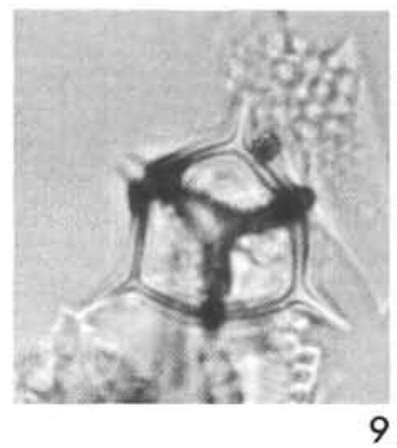
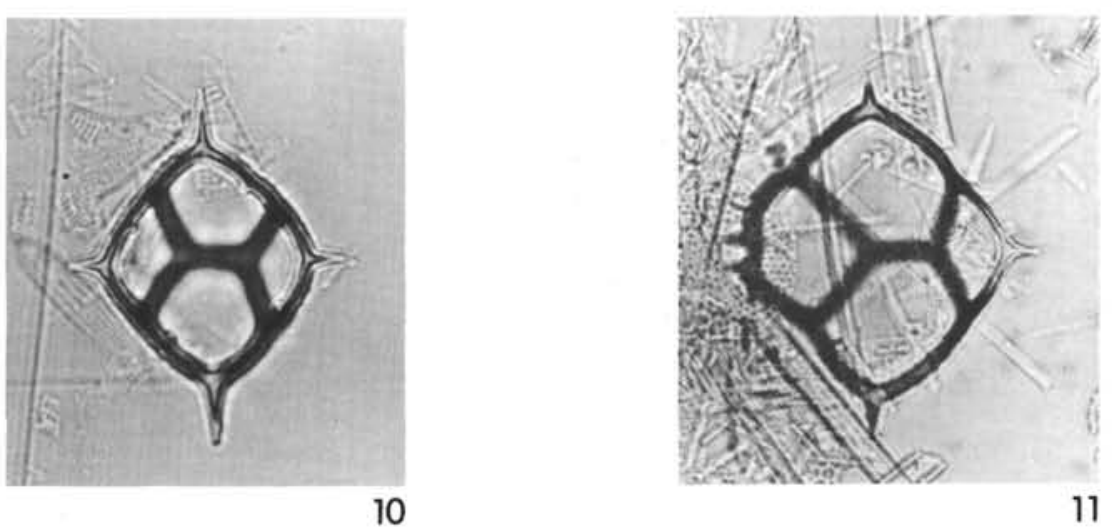


\section{PLATE 4}

Silicoflagellate photomicrographs; $615 \times$ (except Figures 7-9 which are $920 \times$ ).

Figures 2,5 Dictyocha aspera (Lemmermann).

2. Sample $269-8-3,120-122 \mathrm{~cm}$.

5. E $38-8,400-402 \mathrm{~cm}$.

Figures 1,3,4,6 Dictyocha aspera var. pygmaea n. var.

1. E $38-8,400-402 \mathrm{~cm}$.

3. E $38-8,440-442 \mathrm{~cm}$.

4. E $50-28,400-402 \mathrm{~cm}$. Holotype.

6. E $50-28,410-412 \mathrm{~cm}$.

Figures 7-9 Dictyocha deflandrei Frenguelli

7. Sample 274-25-1, 130-132 cm.

8. Sample 274-23-5, 80-82 cm.

9. Sample 274-33-3, 30-32 cm. 
PLATE 4
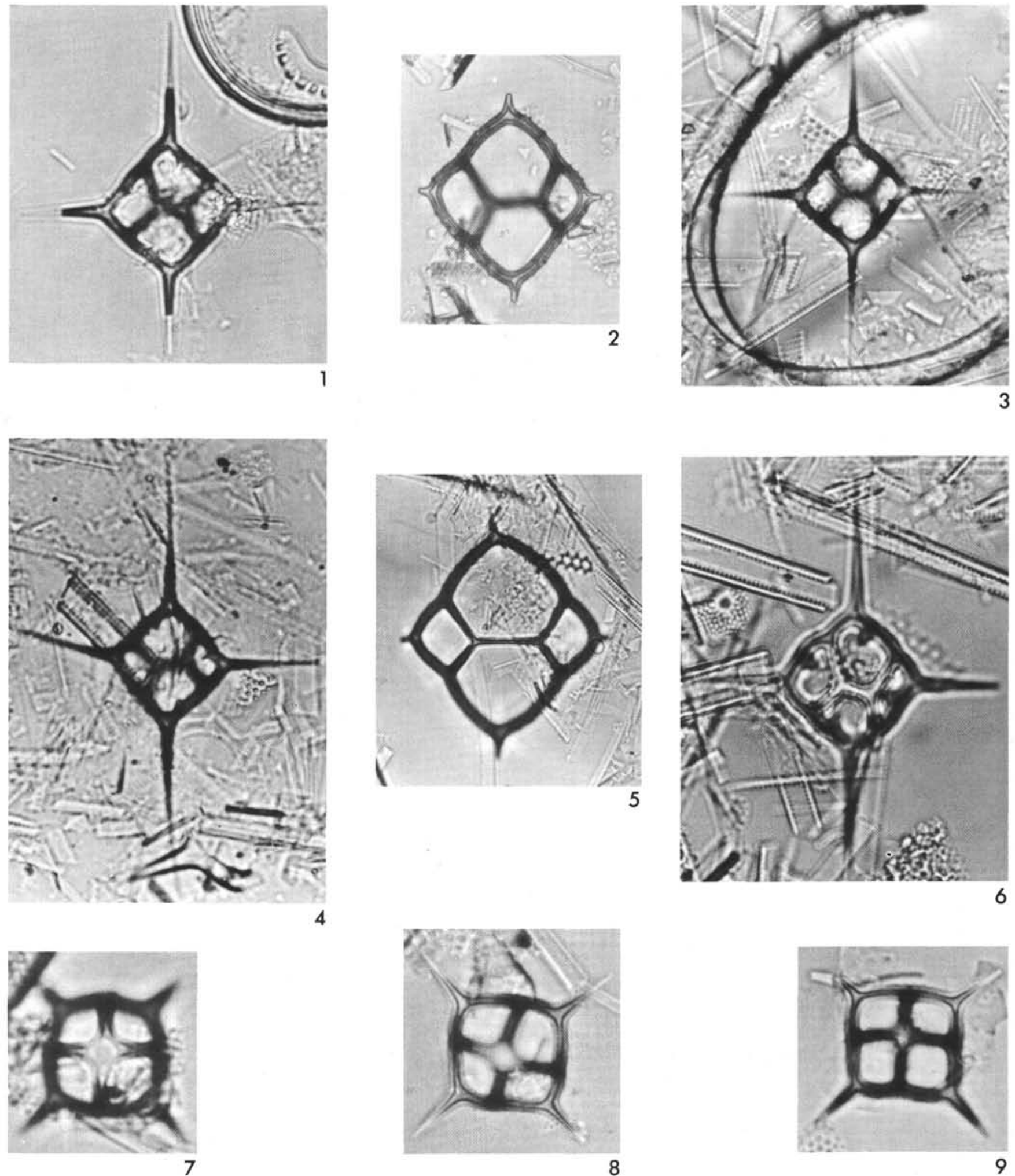
PLATE 5

Silicoflagellate photomicrographs; $820 \times$

(except Figures 1-4 which are $615 \times$ ).

Figures 1-4 Dictyocha fibula Ehrenberg.

E $38-8,460-462 \mathrm{~cm}$.

Figures 5-10 Dictyocha fibula var. pumila n. var.

5. 50-28, 400-402 cm, low focus. Holotype.

6. Same, high focus.

7. E $50-28,415-417 \mathrm{~cm}$.

8. E $38-8,440-442 \mathrm{~cm}$, low focus.

9. Same, high focus.

10. E $50-28,400-402 \mathrm{~cm}$. 


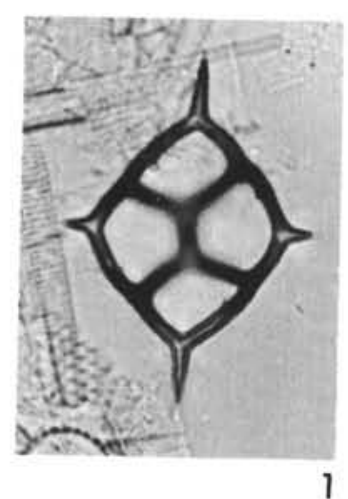

5
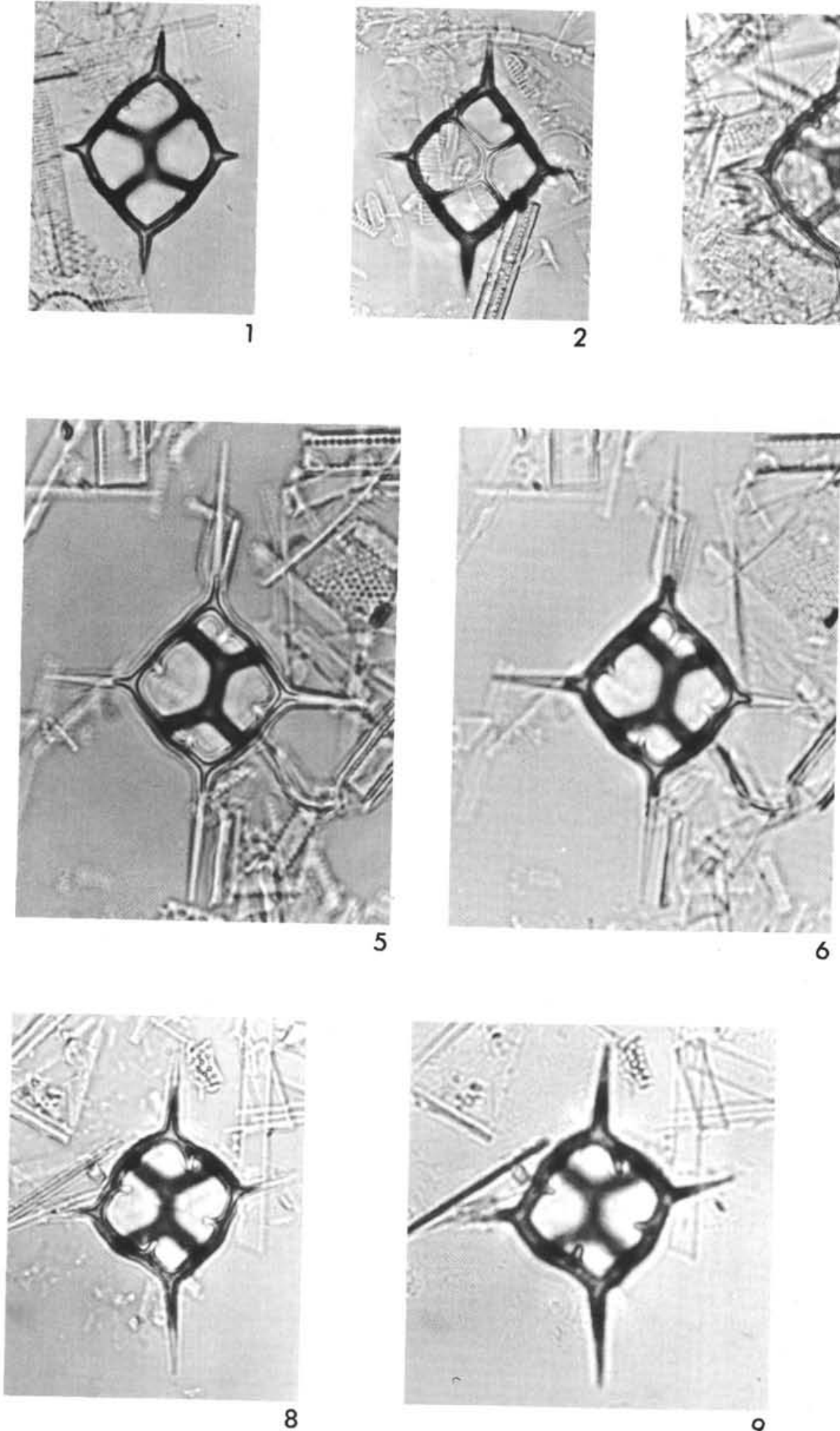
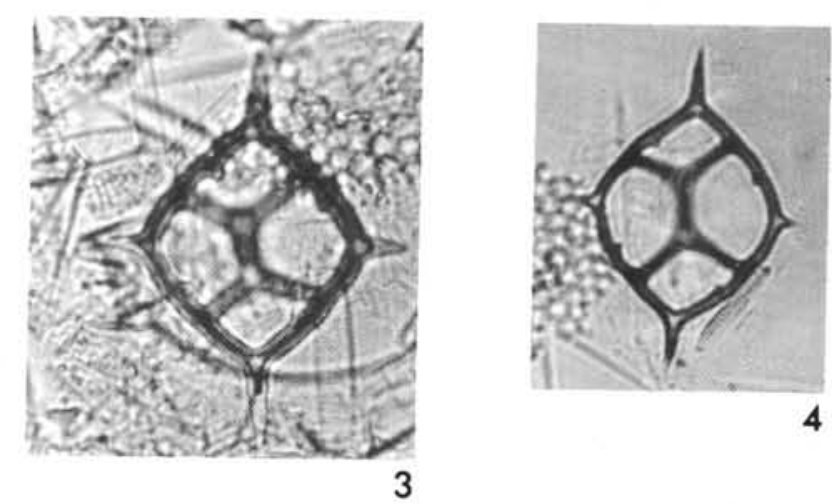
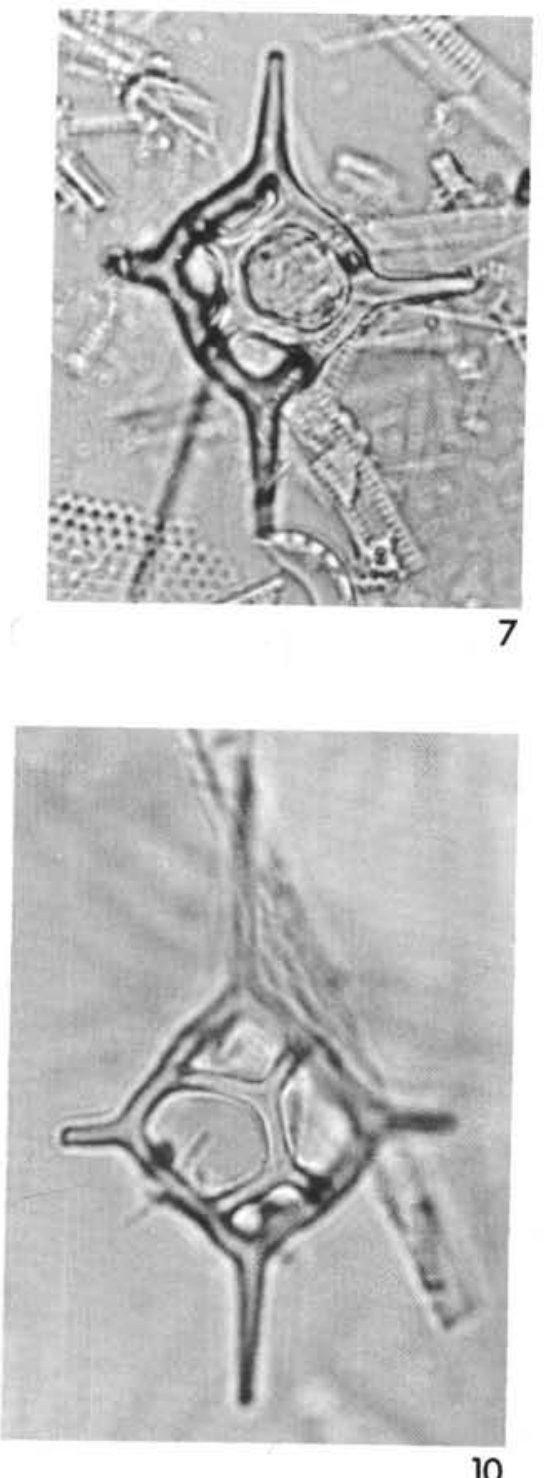


\section{PLATE 6}

Silicoflagellate photomicrographs.

Figures 1,2 Dictyocha fibula var. pumila n. var.

1. E $38-8,400-402 \mathrm{~cm}, \times 1025$.

2. E $50-28,415-417 \mathrm{~cm}, \times 1025$.

Figures 3-9 Dictyocha frenguellii Deflandre.

3. Sample 274-21-6, 30-32 cm, $\times 820$.

4. Sample 274-21-6, 30-32 cm, $\times 820$.

5. Sample 274-20-1, 30-32 cm, $\times 1025$.

6. Sample 274-24-3, 30-32 cm, $\times 1025$.

7. Sample 274-30-6, 30-32 cm, $\times 1025$.

8. Sample 274-22-4, 30-32 cm, $\times 820$.

9. Sample 274-27-4, 30-32 cm, $\times 1025$.

Figures 10,11 Dictyocha hexacantha Schulz.

10. Sample 274-28-5, 30-32 cm, $\times 1025$.

11. Sample 274-28-5, 30-32 cm, $\times 820$. 
PLATE 6
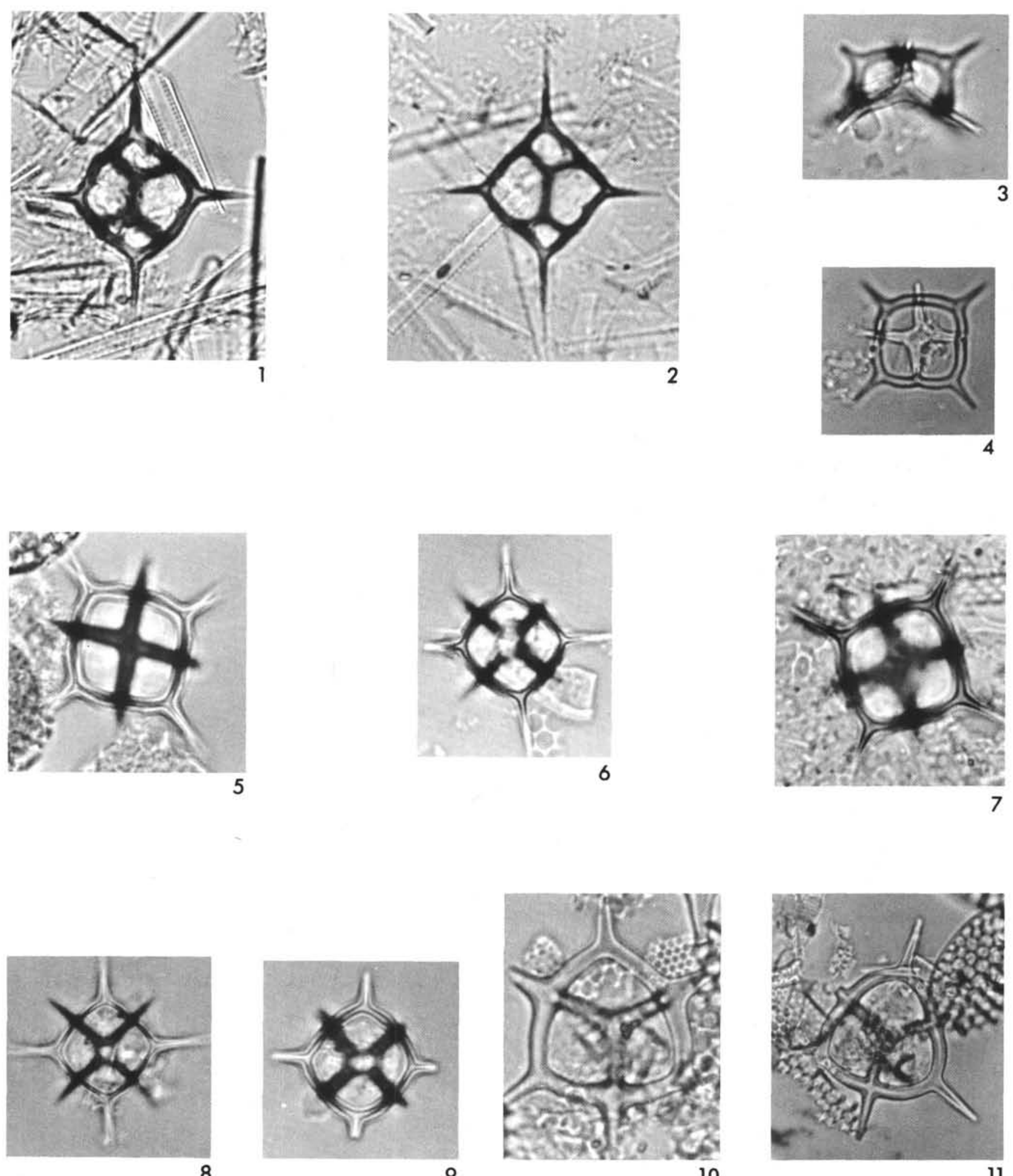

10 


\section{PLATE 7}

Silicoflagellate photomicrographs.

Figures 1-5 Dictyocha mutabilis Deflandre.

Sample 266-13-5, 60-62 cm, $\times 615$.

Figures 6,7 Dictyocha pentagona (Schulz).

6. Sample 266-8-5, 45-57 cm, $\times 1025$.

7. Sample $266-8-4,120-122 \mathrm{~cm}, \times 1025$.

Figures 8-11 Dictyocha pseudofibula (Schulz).

8. Sample 266-8-6, 125-127 cm, $\times 615$.

9. Sample 274-11-4, 90-92 cm, $\times 615$.

10. Sample $266-9-2,30-32 \mathrm{~cm}, \times 615$.

11. Sample $274-11-2,130-132 \mathrm{~cm}, \times 615$.

Figures 12-15 Dictyocha variabilis (Hanna).

12. Sample $274-24-3,30-32 \mathrm{~cm}$, high focus, $\times 1025$.

13. Same, low focus, $\times 1025$.

14. Sample $266-18-1,63-65 \mathrm{~cm}, \times 1025$.

15. Sample $274-24-1,58-60 \mathrm{~cm}, \times 1025$. 

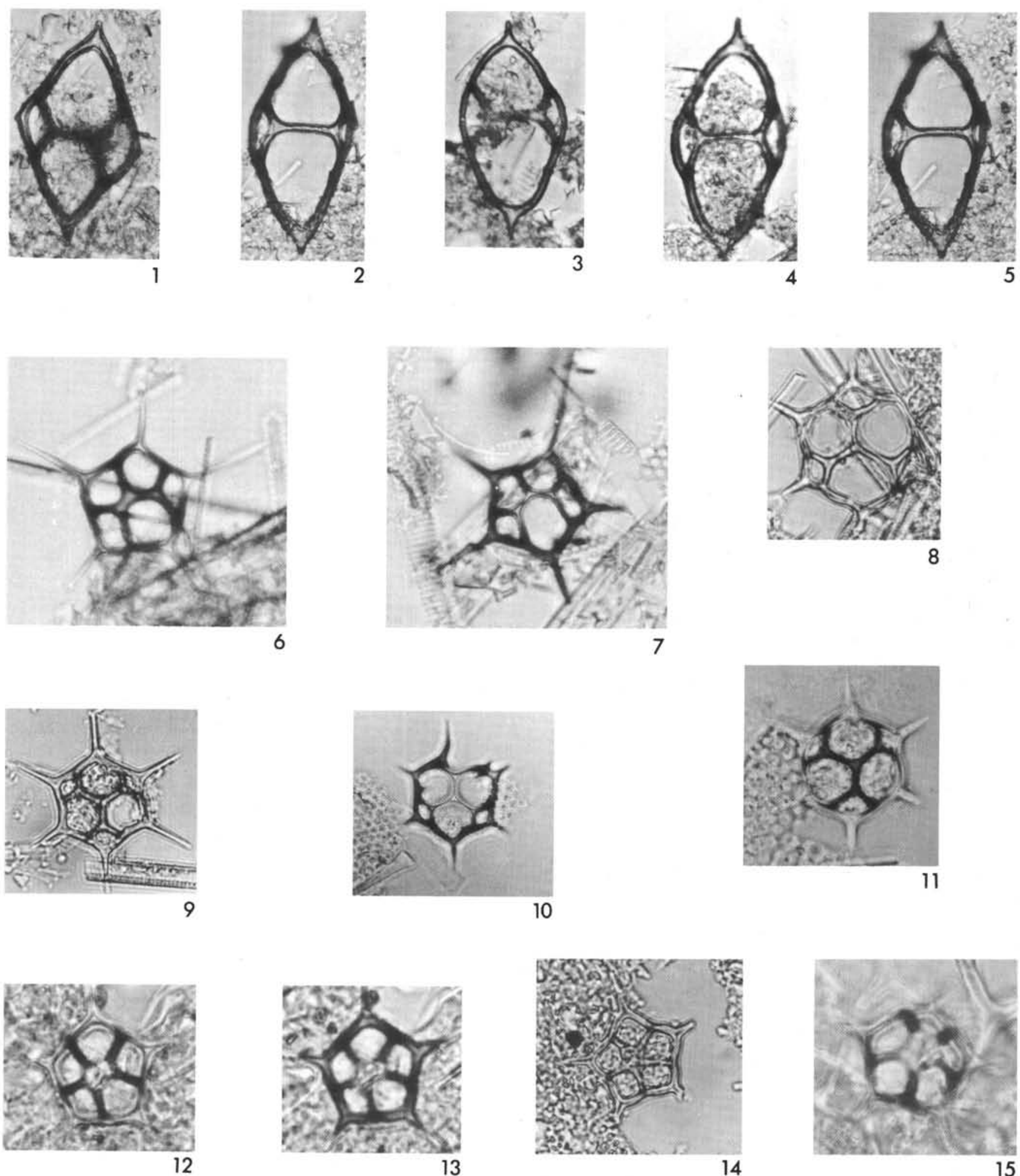


\section{PLATE 8}

Silicoflagellate photomicrographs; $615 \times$.

Figures 1-5 Distephanus boliviensis var. major (Frenguelli).

1. E 50-28, 160-162 cm.

2. Sample 266-6-6, 120-122 cm, high focus.

3. Same, low focus.

4. E $38-7,340-342 \mathrm{~cm}$, low focus.

5. Same, high focus.

Figures 6,7 Distephanus boliviensis var. binoculus (Frenguelli).

6. E 50-28, 160-162 cm.

7. E $38-8,540-542 \mathrm{~cm}$.

Figure $8 \quad$ Distephanus sp. cf. D. boliviensis (Frenguelli). E $50-28,300-302 \mathrm{~cm}$.

Figure 9 Distephanus boliviensis (Frenguelli). Sample 274-11-4, 90-92 cm. 
PLATE 8
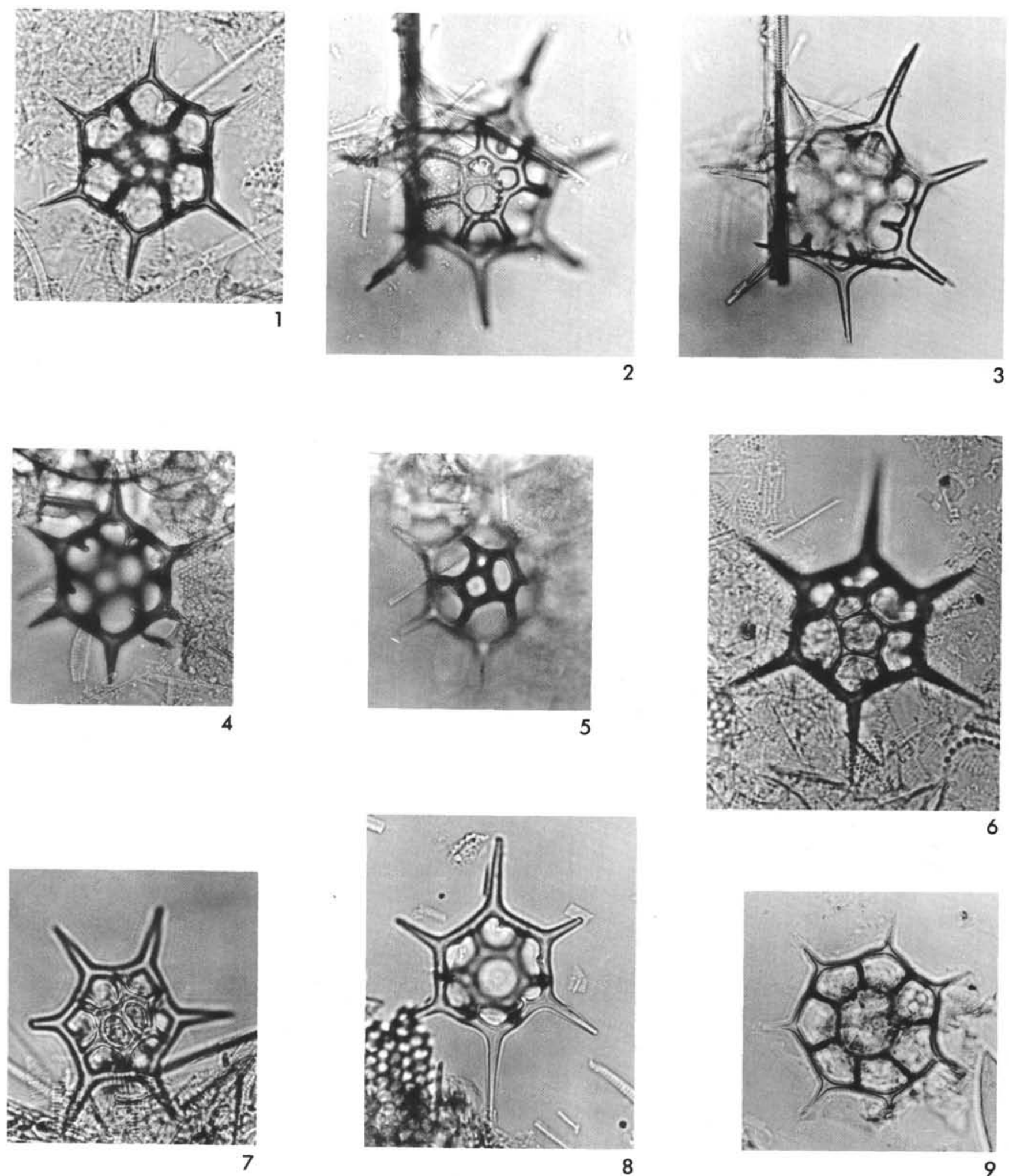


\section{PLATE 9}

Silicoflagellate photomicrographs; $615 \times$.

Figures 1,2 Distephanus cf. D. boliviensis.

1. Sample 274-23-5, 80-82 cm, low focus.

2. Same, high focus.

Figures 3-9 Distephanus crux (Ehrenberg).

3. Sample 274-20-1, 30-32 cm.

4. Sample 274-25-4, 80-82 cm.

5. Sample 274-24-1, $58-60 \mathrm{~cm}$.

6. Sample 274-24-1, $58-60 \mathrm{~cm}$.

7. Sample $266-22-2,60-62 \mathrm{~cm}$.

8. Sample 274-28-1, 30-32 cm.

9. Sample 266-14-3, 60-62 cm.

Figure 10 Distephanus longispinus (Schulz). Sample 266-17-1, 140-142 cm.

Figures 11,12 Distephanus speculum (Ehrenberg).

11. Sample 266-4-3, 100-102 cm.

12. Sample $266-4-2,60-62 \mathrm{~cm}$. 

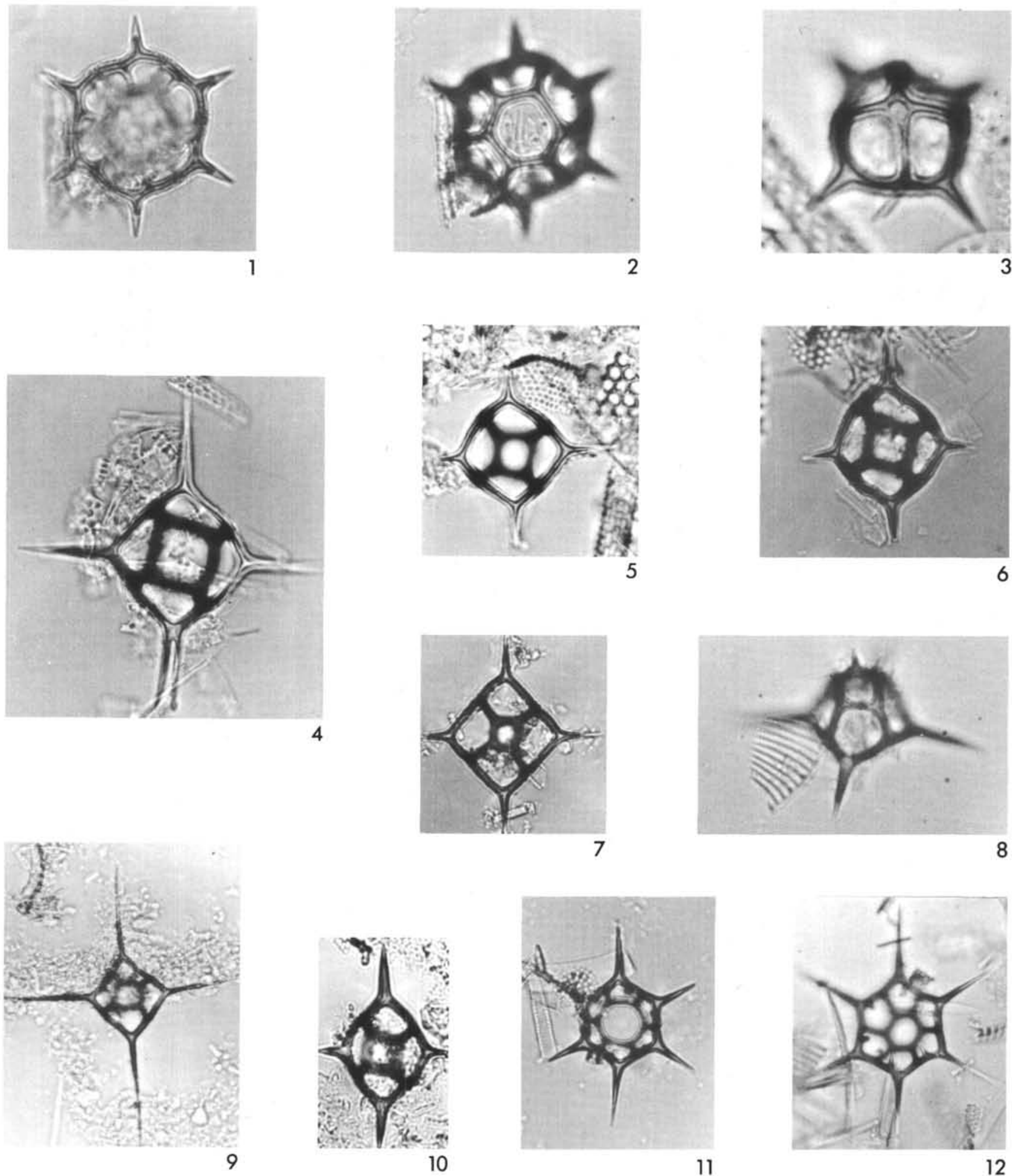
PLATE 10

Silicoflagellate photomicrographs; $615 \times$ (except Figure 9 which is $920 \times$ ).

Figures 1-3 Distephanus speculum (short-spined) (Ehrenberg).

1. Sample 274-1-3, 30-32 cm.

2. Sample $269-1-1,90-92 \mathrm{~cm}$.

3. Sample $269-1-2,90-92 \mathrm{~cm}$.

Figures 4-7 Distephanus speculum var. pentagonus Lemmermann.

4. Sample 266-11-3, 134-136 cm.

5. Sample $266-11-3,134-136 \mathrm{~cm}$.

6. Sample $266-13-5,60-62 \mathrm{~cm}$.

7. Sample 274-11-4, $40-42 \mathrm{~cm}$.

Figure $8 \quad$ Distephanus cf. D. speculum var. pentagonus. Sample 274-24-2, 30-32 cm.

Figures 9,10 Distephanus speculum var. pentagonus f. armata Lemmermann.

9. Sample $266-6-6,120-122 \mathrm{~cm}, \times 920$.

10. Sample 266-6-6, 120-122 cm.

Figure 11 Distephanus speculum var. pentagonus $\mathrm{f}$. geminus. Sample 274-11-4, 40-42 cm. Holotype.

Figures 12-17 Distephanus polyactis (Ehrenberg). Sample 266-4-2, 60-62 cm. 
Plate 10
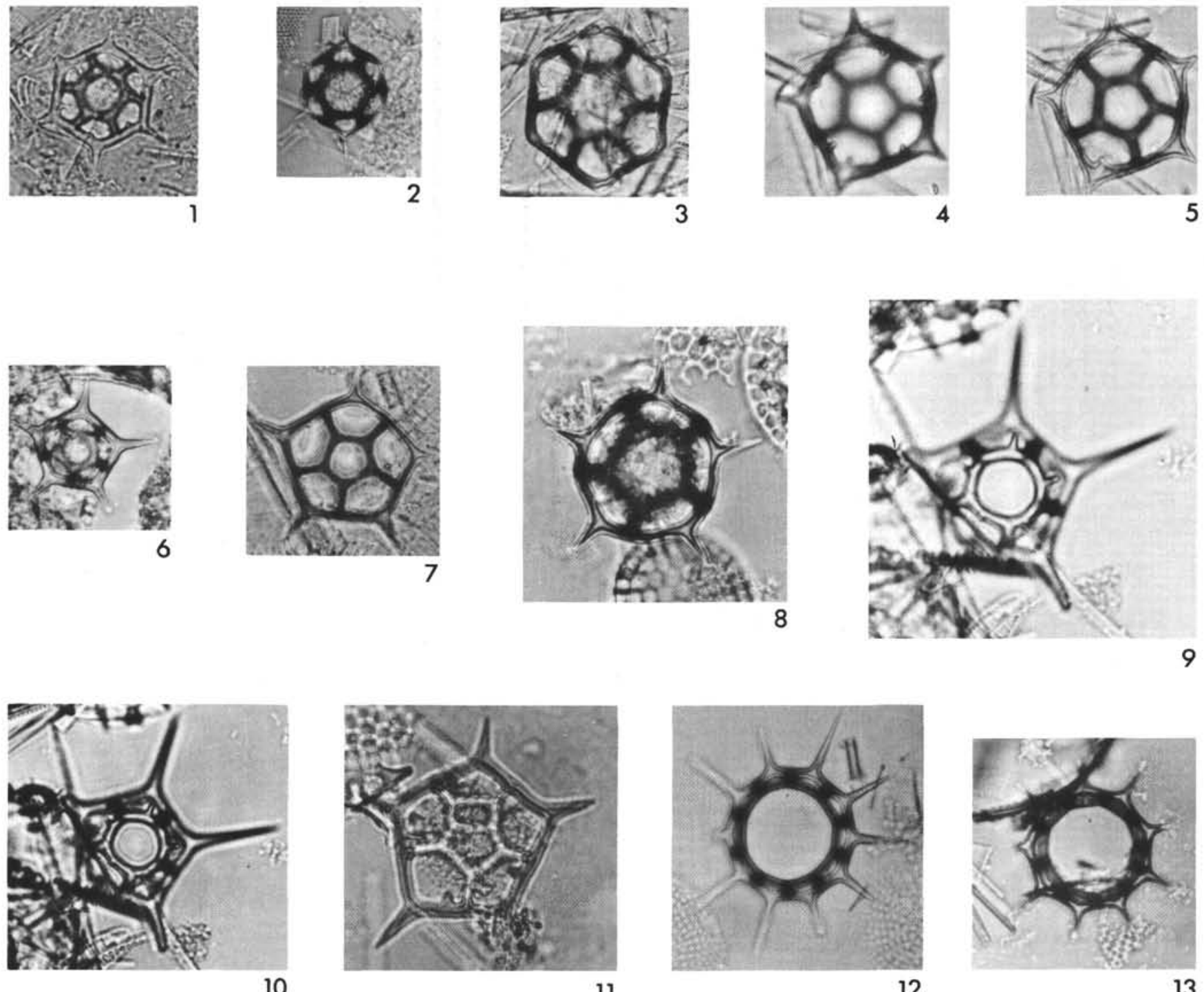

11
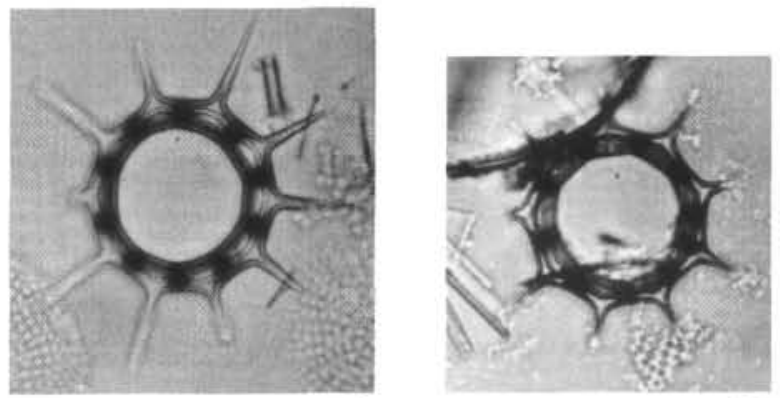

12

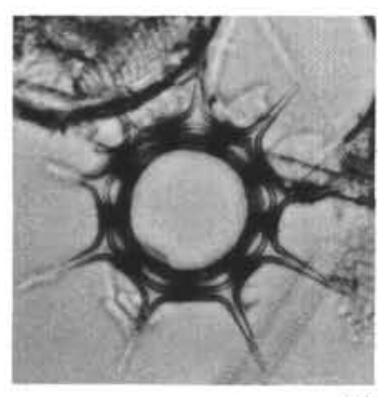

14

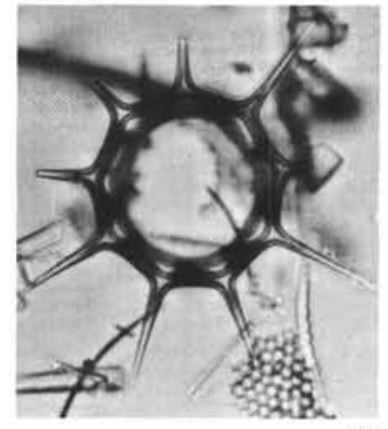

15
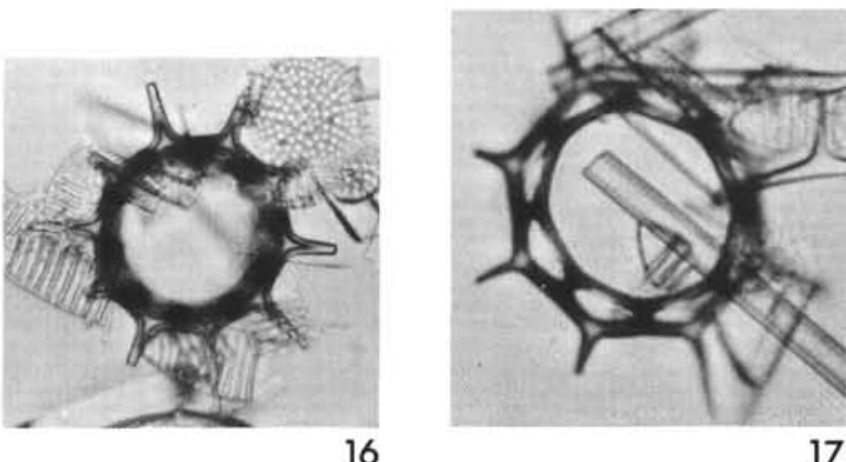

17 


\section{PLATE 11}

Silicoflagellate photomicrographs; $615 \times$.

Figures 1-5 Mesocena apiculata (Schulz).

1. Sample 274-26-1, 30-32 cm.

2. Sample $274-24-3,30-32 \mathrm{~cm}$.

3. Sample 274-24-3, 30-32 cm.

4. Sample 274-23-5, 80-82 cm.

5. Sample 274-24-3, 30-32 cm.

Figures 6,8,9 Mesocena circulus Ehrenberg.

6. Sample 274-12-4, 140-142 cm.

8. Sample $266-11-2,60-62 \mathrm{~cm}$, high focus.

9. Same, low focus.

Figure 7 Mesocena $\mathrm{cf}$. circulus Ehrenberg.

Sample 266-11-2, 60-62 cm. 
PLATE 11
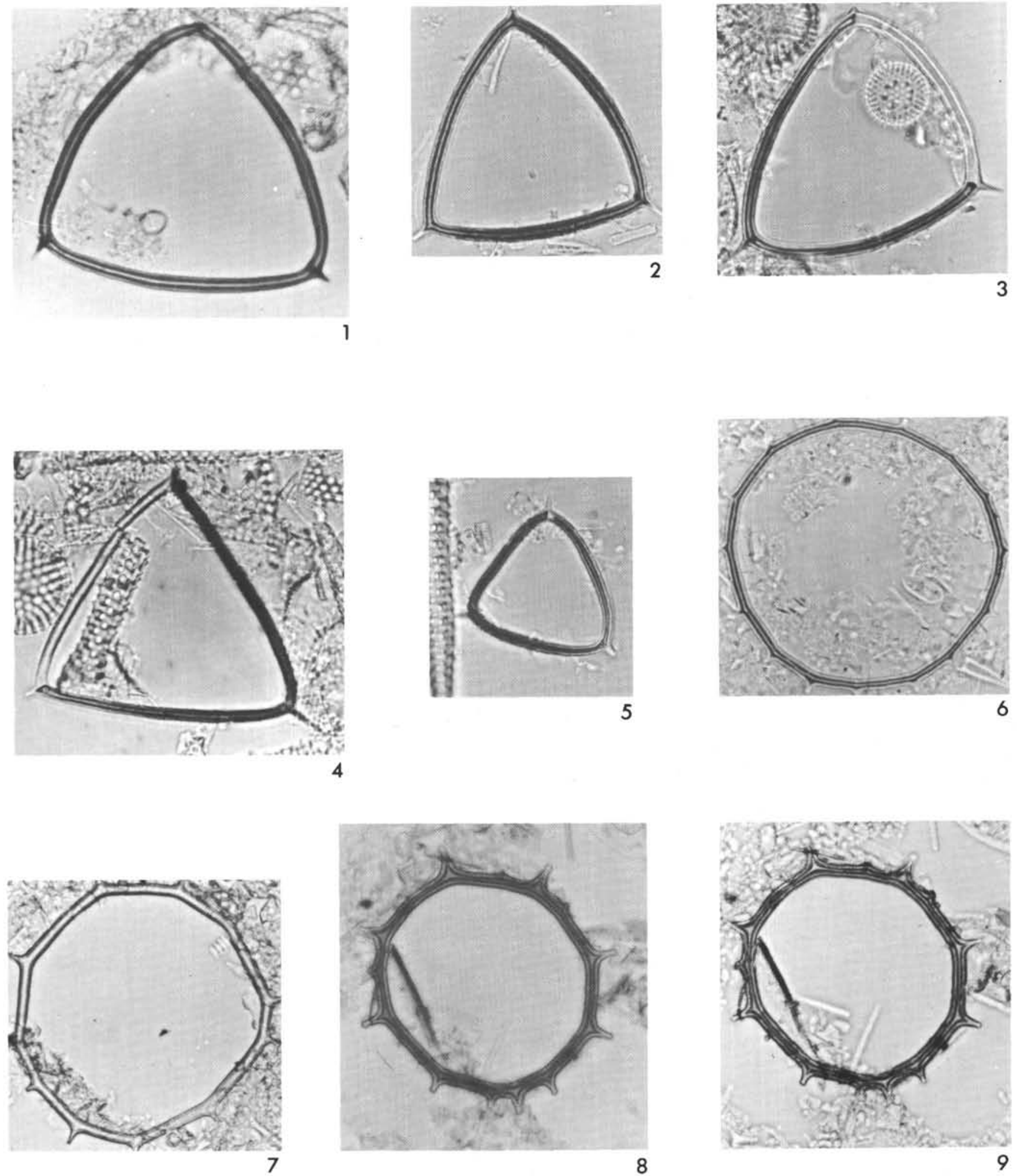


\section{PLATE 12}

Silicoflagellate photomicrographs; $615 \times$.

Figures 1-3 Mesocena diodon Ehrenberg.

1. Sample 266-8-4, 120-122 cm.

2. Sample 266-9-1, 89-91 cm.

3. Sample 266-9-1, 89-91 cm.

Figures 4, 5 Mesocena cf. elliptica.

4. Sample 266-7-5, $45-47 \mathrm{~cm}$.

5. Sample $266-5-5,130-132 \mathrm{~cm}$.

Figure $6 \quad$ Mesocena oamaruensis Schulz. Sample 274-22-5, 30-32 cm.

Figure 7 Mesocena oamaruensis var. quadrangula (Schulz). Sample 266-9-2, 30-32 cm.

Figure 8 Mesocena pappi Bachmann. Sample 266-19-2, 60-62 cm.

Figures 9-11 Naviculopsis biapiculata (Lemmermann).

9. Sample 264-2, CC.

10. Sample $267-4-4,120-122 \mathrm{~cm}$, low focus.

11. Same, high focus. 

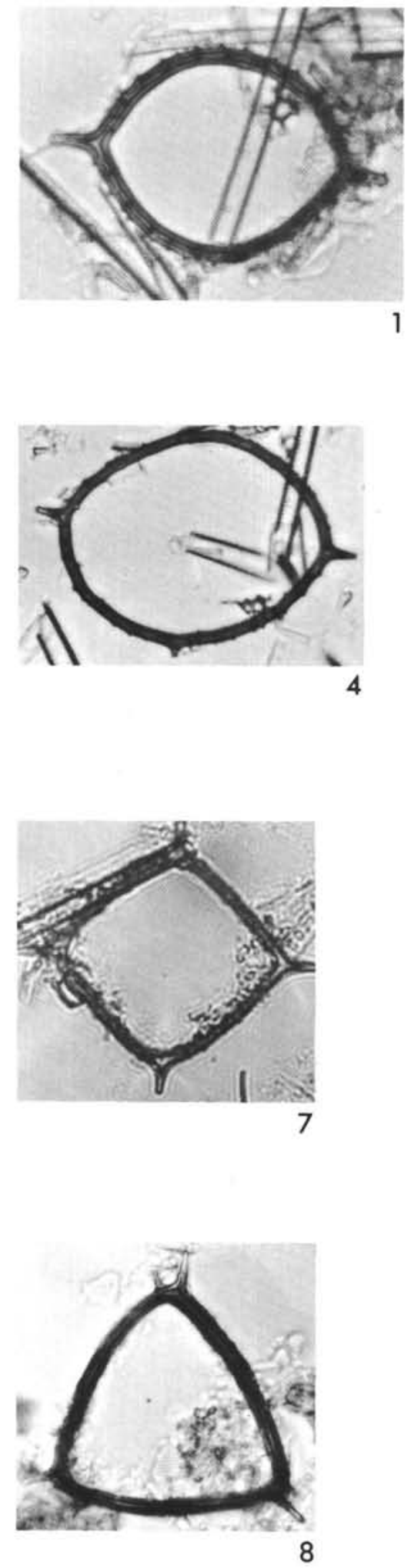
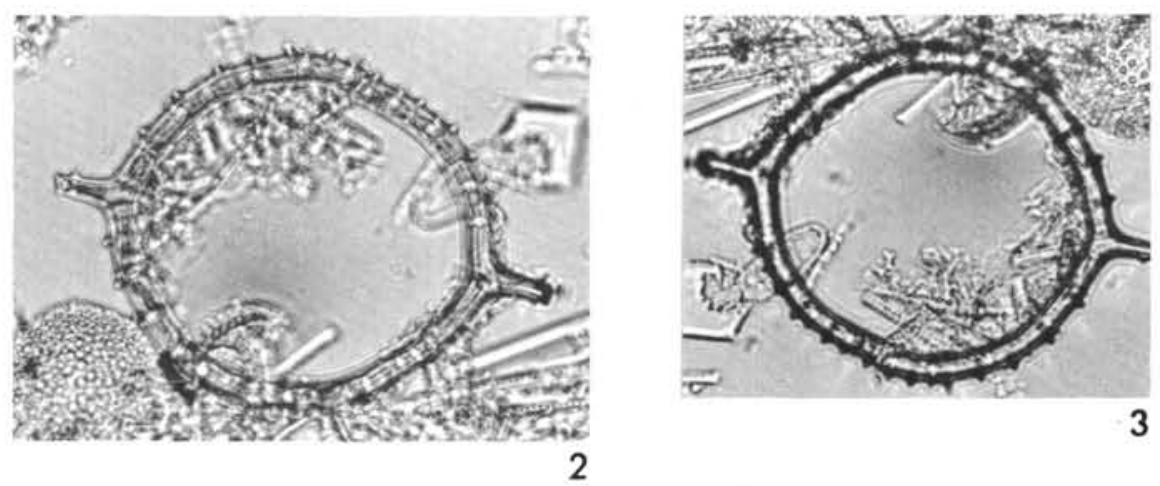
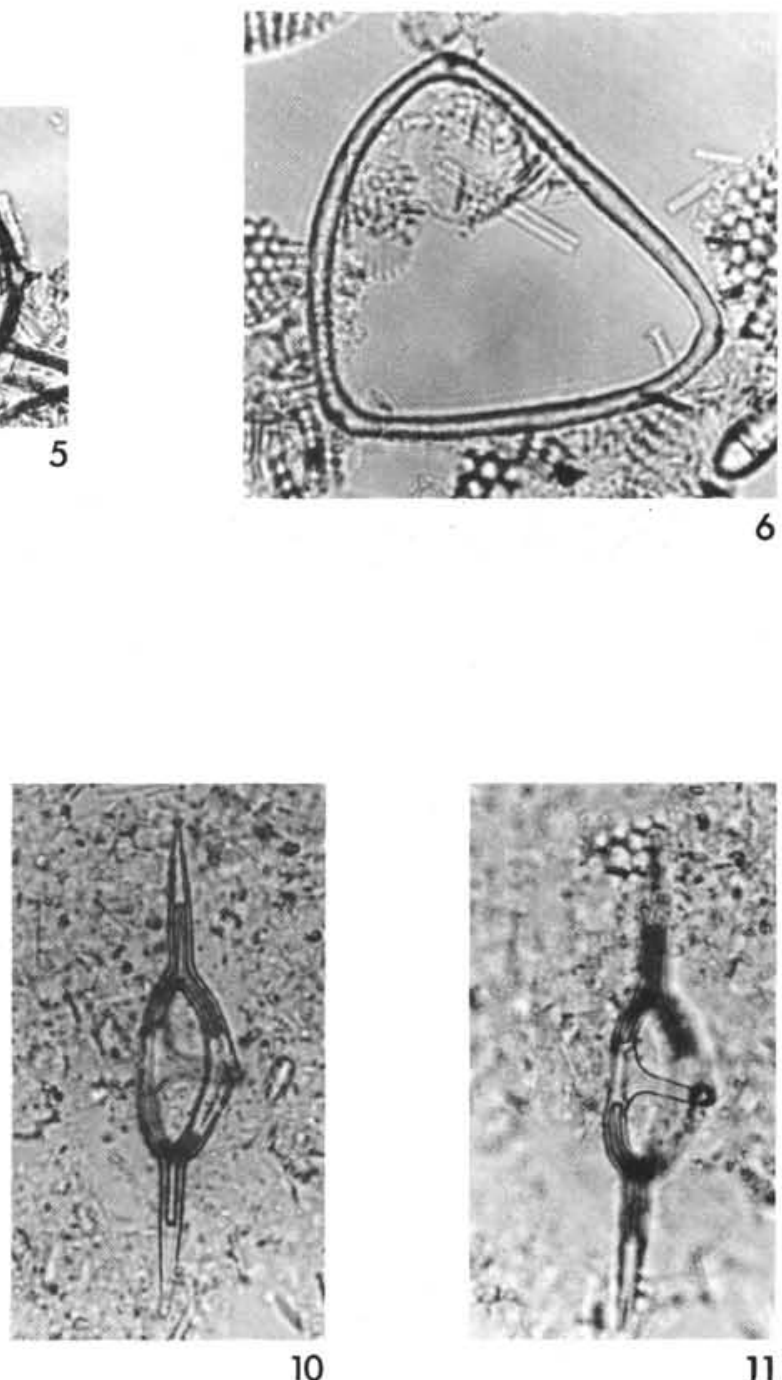

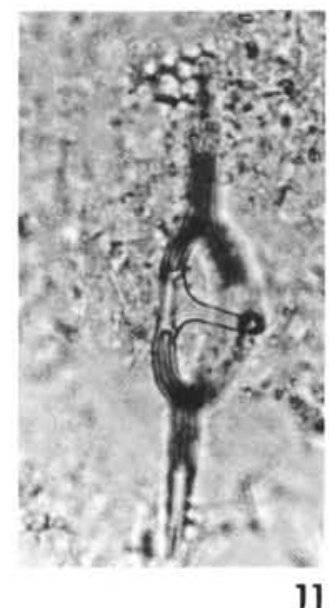




\section{PLATE 13}

Silicoflagellate photomicrographs; $615 \times$.

Figure $1 \quad$ Naviculopsis navicula (Ehrenberg). Sample 266-21-2, 60-62 cm.

Figures 2, 3 Naviculopsis navicula var. naviculopsis (Deflandre).

2. Sample $266-21-2,60-62 \mathrm{~cm}$.

3. Sample $266-21-2,60-62 \mathrm{~cm}$.

Figures 4-7 Naviculopsis regularis (Carnevale).

4. Sample 266-22-2, 60-62 cm.

5. Sample 266-18-3, 60-62 cm.

6. Sample 266-22-2, 60-62 cm.

7. Sample $274-24-1,58-60 \mathrm{~cm}$.

Figures 8-12 Naviculopsis robusta Deflandre.

8. Sample 266-22-1, 60-62 cm.

9. Sample $266-22-1,60-62 \mathrm{~cm}$.

10. Sample $266-22-1,60-62 \mathrm{~cm}$.

11. Sample 266-22-3, 60-62 cm.

12. Sample $266-22-2,60-62 \mathrm{~cm}$.

Figures 13, 14 Naviculopsis trispinosa (Schulz).

13. Sample 274-25-1, 130-132 cm.

14. Sample $274-25-1,130-132 \mathrm{~cm}$. 

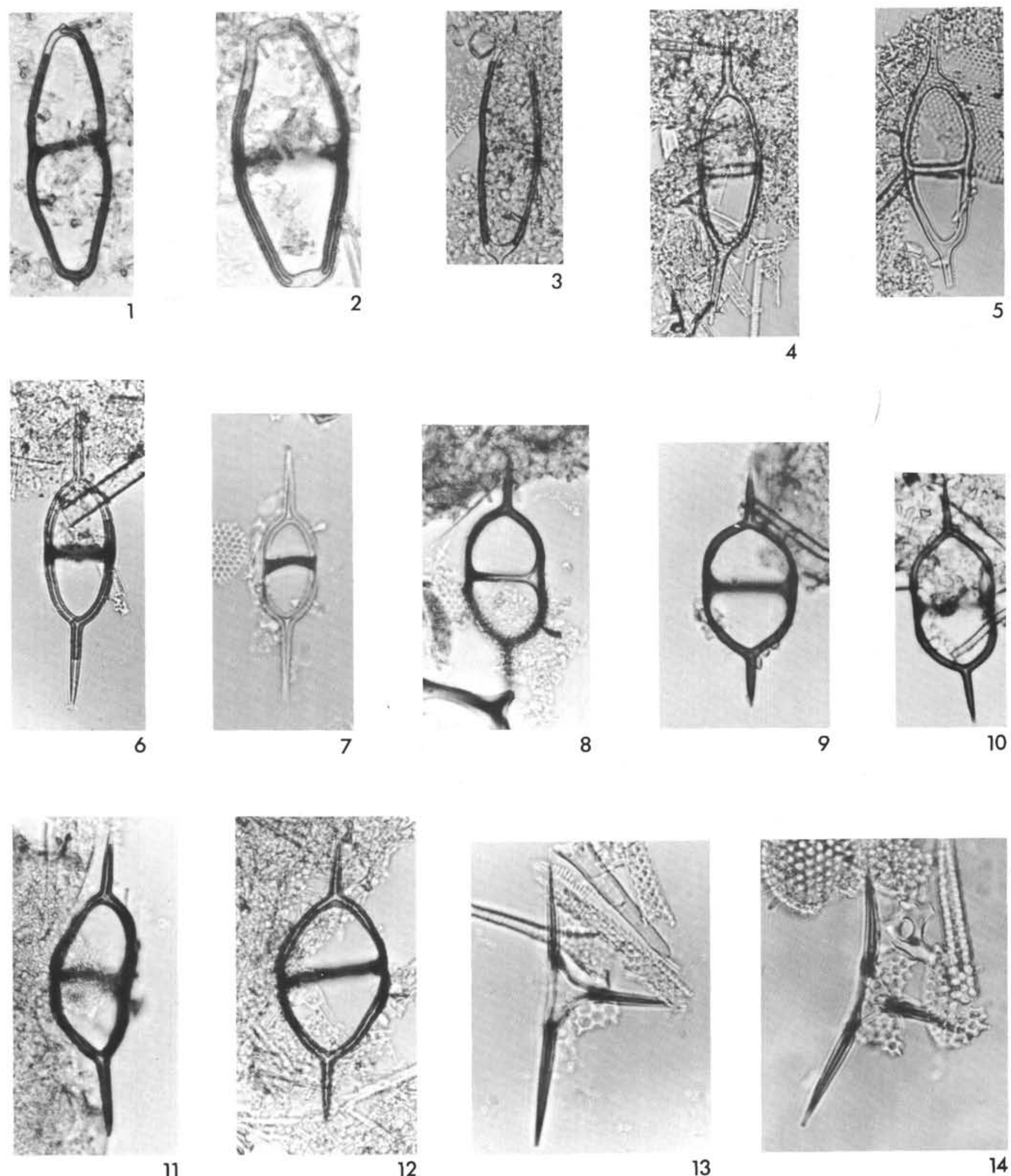

11

12

13

14 